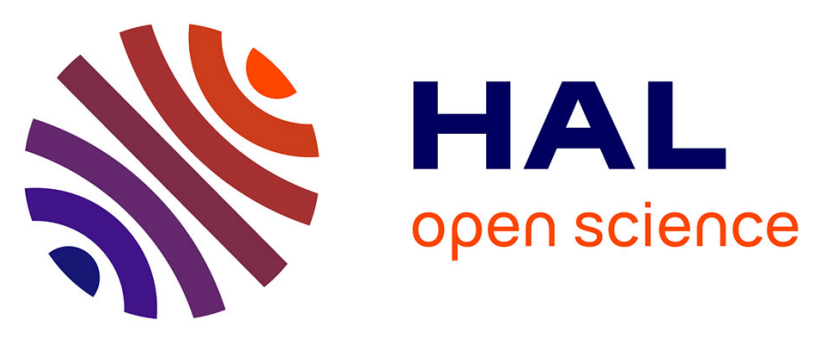

\title{
Review of Iberia-Eurasia plate-boundary basins: Role of sedimentary burial and salt tectonics during rifting and continental breakup
}

Nicolas Saspiturry, Philippe Razin, Thierry Baudin, Riccardo Asti, Yves Lagabrielle, Cécile Allanic, Olivier Serrano, Thibault Duretz

\section{To cite this version:}

Nicolas Saspiturry, Philippe Razin, Thierry Baudin, Riccardo Asti, Yves Lagabrielle, et al.. Review of Iberia-Eurasia plate-boundary basins: Role of sedimentary burial and salt tectonics during rifting and continental breakup. Basin Research, 2021, 33 (2), pp.1626-1661. 10.1111/bre.12529 . insu03046985

\section{HAL Id: insu-03046985 \\ https://hal-insu.archives-ouvertes.fr/insu-03046985}

Submitted on 8 Dec 2020

HAL is a multi-disciplinary open access archive for the deposit and dissemination of scientific research documents, whether they are published or not. The documents may come from teaching and research institutions in France or abroad, or from public or private research centers.
L'archive ouverte pluridisciplinaire HAL, est destinée au dépôt et à la diffusion de documents scientifiques de niveau recherche, publiés ou non, émanant des établissements d'enseignement et de recherche français ou étrangers, des laboratoires publics ou privés. 
4 Nicolas Saspiturry ${ }^{1 *}$, Benoit Issautier ${ }^{2}$, Philippe Razin ${ }^{1}$, Thierry Baudin ${ }^{2}$, Riccardo Asti ${ }^{3}$, Yves

$5 \quad$ Lagabrielle $^{3}$, Cécile Allanic ${ }^{2}$, Olivier Serrano ${ }^{2}$ and Thibault Duretz ${ }^{2}$

$6 \quad{ }^{1}$ Université Bordeaux Montaigne / EA 4592 Géoressources \& Environnement, 1 allée Fernand

7 Daguin, 33607 Pessac cedex, France

$8 \quad{ }^{2}$ Université Rennes, CNRS, Géosciences Rennes - UMR 6118, F-35000, Rennes, France

$9{ }^{3}$ BRGM-French Geological Survey, 3 Avenue Claude Guillemin, 45100 Orléans, France

$10 *$ Corresponding author (e-mail: saspiturry.nicolas@gmail.com)

11 Data sharing is not applicable to this article as no new data were created or analysed in this 12 study.

\section{Acknowledgement}

Iberian-European boundary; Sedimentary burial; Salt tectonics; Depth-dependent thinning;

This work is part of Saspiturry's Ph.D. research conducted as part of the OROGEN project, cofunded by Total S.A., Bureau de Recherches Géologiques et Minières (BRGM), and Institut National de Sciences de l'Univers (INSU). We thank OROGEN project managers Sylvain Calassou (Total), Emmanuel Masini (Total), Olivier Vidal (CNRS, Centre National de la Recherche Scientifique) and Isabelle Thinon (BRGM). We specially thank Basin Research's deputy editor Kerry Gallagher and the three reviewers, Tiago M. Alves, Per Terje Osmundsen and Nicholas Christie-Blick for their constructive comments, which significantly improved the initial manuscript.

\section{Keywords}

Ductile regime; HT/LP metamorphism 


\section{Abstract}

We document the role of sedimentary burial and salt tectonics in controlling the deformation style of continental crust during hyperextension. The Iberian-European boundary records a complex history of Cretaceous continental extension, which has led to the development of socalled smooth-slope type basins. Based on the review of the available geological constraints (crustal-balanced cross sections, sedimentary profile evolution, RSCM thermometer, lowtemperature thermochronology) and geophysical data (Bouguer anomaly, Moho depth, seismic reflection profiles, and $\mathrm{Vp} / \mathrm{Vs}$ velocity models) on the Tartas, Arzacq, Cameros, Parentis, Columbrets, Mauléon, Basque-Cantabrian and Internal Metamorphic Zone basins, we shed light on the main characteristics of this type of basin. This synthesis indicates that crustal thinning was influenced by two decoupling horizons: the middle crust and Triassic pre-rift salt, initially located between the basement and pre-rift sedimentary cover. These two horizons remained active throughout basin formation and were responsible for depthdependent thinning of the crust and syn-rift salt tectonics. We therefore identify several successive deformation phases involving (1) pure shear dominated thinning, (2) simple shear dominated thinning and (3) continental breakup. In the first phase, distributed deformation resulted in the development of a symmetric basin. Field observations indicate that the middle and lower crust were under dominantly ductile conditions at this stage. In the second phase, deformation was localized along a crustal detachment rooted between the crust and the mantle and connecting upwards with Triassic pre-rift salt. During continental breakup, basin shoulders recorded the occurrence of brittle deformation while the hyperextended domain remained under predominantly ductile thinning. The formation of smooth-slope type extensional basins was intrinsically linked to the combined deposition of thick syn-rift and breakup sequences, and regional salt tectonics. They induced significant burial and allowed 
the continental crust and the pre-rift sequence to deform under high temperature conditions

50 from the rifting to continental breakup stages.

\section{$51 \quad 1$ Introduction}

Recent models and concepts related to hyperextended continental margins have been defined on North Atlantic passive margins such as West Iberia/Newfoundland (Boillot et al., 1980, 1995; Reston et al., 1995; Whitmarsh et al., 2001; Péron-Pinvidic \& Manatschal, 2009; PéronPinvidic et al., 2015), Norway/Greenland (Osmundsen et al., 2002; Osmundsen \& Ebbing, 2008; Osmundsen \& Péron-Pinvidic, 2018), and the Alps (Lemoine et al., 1987; Froitzheim \& Manatschal, 1996; Manatschal \& Nievergelt, 1997; Manatschal et al., 2006; Masini et al., 2011; Mohn et al., 2014). They describe the mechanisms responsible for continental crust thinning and subcontinental mantle exhumation at the ocean-continent transition, and have shown that the hyperextended domain of continental margins is characterized by (1) sediment starved conditions with very thin pre-rift and syn-rift sedimentary sequences, (2) asymmetric margins, and (3) coupled deformation between the basement and sedimentary cover resulting in the formation of extensional allochthons. The syn-rift and post-rift units have been respectively defined as strata deposited during (1) the last extension episode leading to continental breakup and (2) a period of relative tectonic quiescence above a regional breakup unconformity (Driscoll et al., 1995; Wilson et al., 2001). DSDP and ODP drilling expeditions along the West-Iberia margin have also contributed to a more complete understanding of how continental breakup is recorded in syn-rift to post-rift sedimentary sequences (Alves \& Cunha, 2018), and how it evolves through time along the strike of continental margins (Alves et al., 2009). Indeed, such data allowed the identification of syn-rift, breakup and post-rift sequences as correlating with major phases of crustal thinning, mantle denudation and oceanic spreading (Alves et al., 2009; Soares et al., 2012; Soares, 2014; Alves \& Cunha, 2018; Alves et al., 
2020). Continental breakup is thus defined as the deposits that are correlated with the phases of hyperextension and mantle denudation on magma-poor continental margins (Soares et al., 2012). Alves et al. (2020) have demonstrated that continental breakup is only possible along magma-poor Type I margins (sensu Huismans \& Beaumont, 2003, 2008, 2011, 2014). Indeed, the upper lithosphere in Type I margins is much more coupled to the continental crust than in Type II margins (Alves et al., 2020). Thus, along Type II margins, the upper lithosphere is laterally subtracted and mantle denudation cannot occur. Syn-rift and breakup sequences are delimited by major unconformities corresponding (from bottom to top) to the base syn-rift unconformity (BSU; base of syn-rift sequence), the lithospheric breakup surface (LBS; base of the breakup sequence) and the base post-rift unconformity (BPU; base of the post-rift sequence) as defined by Soares et al. (2012) and Soares (2014). While Atlantic-type margins develop under conditions of high mantle heat flow, as the product of asthenosphere upwelling and subsequent denudation of subcontinental mantle (e.g., Huismans \& Beaumont, 2003, 2008, 2011, 2014; Lavier \& Manatschal, 2006; Brune et al., 2014, 2016), the North Pyrenean hyperextended rift system differs from the Atlantic type by the presence of hightemperature/low-pressure (HT/LP) metamorphism (Albarède \& Michard-Vitrac, 1978a, 1978b; Golberg et al., 1986; Montigny et al., 1986; Golberg \& Maluski, 1988; Golberg \& Leyreloup, 1990; Thiébaut et al., 1992). The North Pyrenean rift basins were affected by a syn-rift stage throughout the Early Cretaceous that evolved to continental breakup and mantle denudation during the Latest Albian to Early Cenomanian (Debroas et al., 2010; Saspiturry et al., 2019a; Espurt et al., 2019; Labaume \& Teixell, 2020). Thus, these margins can be defined as Type I margins as mantle denudation occured during continental breakup (sensu Huismans \& Beaumont, 2003, 2008, 2011, 2014). The hyperextended domain of these basins is interpreted to have stretched under high-temperature conditions under a predominantly ductile regime, resulting in the generation of large-scale boudins whose formation was controlled by 
a strong thermal and structural inheritance (Clerc \& Lagabrielle, 2014; Clerc et al., 2015, 2015b; Corre et al., 2016; de Saint Blanquat et al., 2016; Teixell et al., 2016; Lagabrielle et al., 2016, 2019; Asti et al., 2019). The major difference between the hyperextended Atlantictype and Pyrenean Cretaceous rift margins is the rare occurrence of tilted crustal blocks and related stepping fault scarps in the central parts of the basins, thus defining a dominantly symmetrical basement profile with smooth slopes (see Lagabrielle et al., 2020 for a review). Several other rift basins apart from the North Pyrenean rift basins exist along the plate boundary separating Iberia from the Eurasia plate and share several features in common with the Pyrenean system. They include the Tartas, Arzacq, Columbrets, Cameros and Parentis syn-rift basins, which developed during Late Jurassic to Early Cretaceous rifting (more details in the review section). The development of these basins is time-equivalent to the Late Jurassic-Aptian rifting and Albian-Cenomanian breakup sequence of the V-shaped Bay of Biscay margin (Montadert et al., 1979; Barbier et al., 1986; Thinon, 1999; Vergés \& GarcíaSenz, 2001; Thinon et al., 2003; Tugend et al., 2014) and the NW-Iberia margin (Soares et al., 2012; Alves \& Cunha, 2018; Alves et al., 2020). All of these basins share similarities that include (1) a small amount of brittle deformation affecting the upper crust, (2) a pre-rift cover that is efficiently decoupled from its substratum thanks to the thick layer of Late Triassic to earliest Jurassic evaporites, (3) hyperthinned continental crust resulting from a polyphase rifting history, (4) a thick pre-rift to syn-rift sedimentary pile and (5) HT/LP syn-rift metamorphism. This paper presents a structural and sedimentological review of these smoothslope type basins that sheds light on the major role of sedimentary burial and decoupling levels in controlling the ductile crustal thinning of the Iberia-Eurasia plate boundary basins during the syn-rift and breakup stages. We also compare the processes responsible for continental crust thinning and discuss the timing of formation of the smooth-slope type basins 
with respect to the evolution of the West Iberia and Bay of Biscay hyperextended continental margins.

\section{Mesozoic basins of Iberia and Europe}

\subsection{Aquitaine basin and the Tartas and Arzacq basins}

The Aquitaine basin started to develop during the Late Permian in an extensional context related to the breakup of Pangea (Burg et al., 1994). During the Triassic and earliest Jurassic (Hettangian), extension led to an aborted rift basin filled with clastic rocks, carbonates, and an evaporite sequence $\sim 1-2$ km thick (Curnelle et al., 1982; Curnelle, 1983; Curnelle \& Dubois, 1986). The Jurassic was a tectonically stable period marked by the development of a widespread carbonate platform (Peybernès, 1976). At the end of the Jurassic, the entire platform was confined as suggested by the deposition of restricted dolomite and anhydrite facies (BRGM et al., 1974; Serrano et al., 2006). The Jurassic pre-rift carbonate platform was uplifted, weathered and partly eroded (Combes et al., 1998; James, 1998; Canérot et al., 1999) in response to asthenosphere upwelling that preceded Early Cretaceous rifting (Saspiturry et al., 2019a). The Early Cretaceous was a structurally active time in which the Aquitaine basin evolved into different syn-rift basins characterised by very rapid subsidence (up to 130 m/Myr; Désaglaux \& Brunet, 1990; Brunet, 1991), including the symmetric Arzacq and Tartas basins. A $\sim 1-3 \quad \mathrm{~km}$ thick Early Cretaceous syn-rift sedimentary sequence unconformably overlies pre-rift deposits of Triassic and Jurassic age totalling $2-3 \mathrm{~km}$ in thickness (Serrano et al., 2006).

\subsubsection{Tartas basin}

The Tartas basin is located in the southern part of the Aquitaine domain (Fig. 1). It is bounded to the north by the Celtaquitaine Flexure (BRGM et al., 1974), which separates the Tartas Basin and the North Aquitaine Platform, and to the south by the Audignon-Pécorade-Antin 
146 Maubourguet ridge. The Tartas basin is a relatively narrow $(20 \mathrm{~km})$ east-west elongated

147 trough (Serrano et al., 2006) that lies on slightly thinned continental crust (20-25 km; Wang

148 et al., 2016). It formed symmetrically during the Berriasian with the development of

149 widespread shallow-water facies and continued this pattern throughout Early Cretaceous

150 continental rifting. Sediments from this period range from marginal littoral facies (Berriasian

151 to Barremian; e.g., Issautier et al., 2018) to inner-platform facies (Aptian and Albian; e.g.,

152 Delfaud, 1969; Arnaud-Vanneau et al., 1979; Bouroullec et al., 1979; Peybernès, 1979, 1982).

153 Throughout the Early Cretaceous rifting, the balance between carbonate production and basin

154 subsidence in the Tartas basin led to the aggradation of a shallow-marine carbonate 155 succession $2500 \mathrm{~m}$ thick. The resulting palaeogeography was a homogeneous, flat-floored 156 basin with no major brittle deformation recorded within the basin. High subsidence rates are 157 consistent with ductile pure shear thinning of the lower/middle crust and formation of a 158 symmetric syn-rift basin (Issautier et al., 2020). This regime was probably enhanced by the 159 presence of a thick evaporite layer of Rhaetian-Hettangian age that favoured mechanical 160 decoupling between the pre-rift sediments and the basement. This salt blanket may account 161 for the lack of illustrated brittle structures in the syn-rift succession of the Tartas basin 162 (Issautier et al., 2020).

\subsubsection{Arzacq basin}

164 The Arzacq syn-rift basin lies to the south of the Tartas basin (Fig. 1). Similarly to the

165 Tartas basin, it is $40 \mathrm{~km}$ wide, elongated in the $\mathrm{N} 110^{\circ}$ direction and overlies slightly thinned 166 continental crust nearly $25 \mathrm{~km}$ thick (Wang et al., 2016). The Arzacq basin is bounded to the 167 north by the Audignon-Pécorade-Antin Maubourguet ridge (Mauriaud, 1987; Mediavilla, 168 1987; Serrano et al., 2006) and to the south by the North Pyrenean Frontal Thrust 169 (Choukroune \& ECORS Team, 1989; Daignières et al., 1994; Bourrouilh et al., 1995). Its southern flank coincides with north-dipping normal faults on the south side of the Grand Rieu 
171 ridge (Fig. 2) (e.g., Serrano et al., 2006; Masini et al., 2014; Gómez-Romeu et al., 2019;

172 Saspiturry et al., 2019a). Early Mesozoic rifting (Triassic to Hettangian) was responsible for a

173 high subsidence rate and the deposition of a thick anhydrite sequence (Curnelle, 1983). The

174 basin's subsequent rifting history was characterised by two successive extensional regimes,

175 the first one symmetric (Berriasian to Aptian) and the second one slightly asymmetric

176 (Albian) (Issautier et al., 2020). The symmetric syn-rift stage, identical to that of the Tartas

177 basin, was accommodated by ductile flow of the lower/middle continental crust. Again, no

178 brittle structures are recorded, probably because deformation was decoupled by the thick salt

179 blanket (Canérot et al., 2005; Duretz et al., 2019). From Berriasian to Barremian times, the

180 palaeogeography was dominated by a shallow marginal carbonate platform (e.g., Bouroullec

181 \& Deloffre, 1970; Peybernès \& Combes, 1994; Biteau et al., 2006; Biteau \& Canérot, 2007).

182 In late Aptian times, the basin differentiated with the growth of a median marl flanked by 183 carbonate-reef and inner-platform deposits (Delfaud \& Gautier, 1967; Delfaud \& Villanova, 184 1967). This second stage began during the Albian with a sudden change in both 185 palaeogeography and basin geometry, when the depositional profile became asymmetric and 186 salt tectonics affected its flanking ridges (Fig. 2; Issautier et al., 2020). Halokinesis consisted 187 of gliding displacement of the Grand Rieu sedimentary cover on the southern side of the basin 188 (Fig. 2), leading to the development of salt-detached ramp synclines as defined by Jackson 189 and Hudec, (2005) and Pichel et al. (2018). Salt diapirism in the Audignon district in the 190 northern side of the basin accompanied this stage (Mauriaud, 1987; Mediavilla, 1987; 191 Issautier et al., 2020). As the syn-rift stage continued, the gliding of the sedimentary cover 192 occurred. Motion resulted from simple shear strain localisation along an Albian detachment 193 fault that followed ductile pure shear thinning of the lower/middle crust during the Barremian194 Aptian interval (Issautier et al., 2020). The subsidence history of the Arzacq syn-rift basin 195 also shows that the second stage coincided with an unusually steep geothermal gradient that 
ended around the initiation of the Pyrenean compression (Angrand et al., 2018). The post-rift

197 stage was marked by the deposition of Cenomanian shallow-water carbonates resting unconformably on Albian strata. Although this basin underwent simple shear thinning during the Albian, it did not reach the stage of continental breakup.

\subsection{Cameros basin}

201

202

203

204

205

206

207

208

209

The Cameros basin, on the northwestern edge of the Iberian mountain chain (Fig. 1), is a WNW-ESE trending synclinorium $80 \mathrm{~km}$ wide and $120 \mathrm{~km}$ long resulting mostly from Early Cretaceous rifting (Guimerà et al., 1995) (Fig. 3). The basin infill has been thrusted onto neighbouring Cenozoic basins, the Ebro basin to the north and the Duero basin to the south (Fig. 3E). It underwent separate rifting stages from Permian to Triassic (Alvaro et al., 1979) and Late Jurassic to Early Cretaceous times (Platt, 1990; Mas et al., 1993; Casas-Sainz \& GilImaz, 1998; Salas et al., 2001). The Late Jurassic to Early Cretaceous rifting stage was followed by Late Albian thermal subsidence recording the post-rift stage (Omodeo Salè et al., 2014; Omodeo-Salé et al., 2014, 2017). The associated Late Jurassic to Early Cretaceous synrift sequence ranges from 6.5 to $8 \mathrm{~km}$ in thickness (Fig. 3) (Casas-Sainz \& Gil-Imaz, 1998; Mas et al., 2011; Omodeo-Salé et al., 2014; García-Lasanta et al., 2017).

The base of the Mesozoic sedimentary pile of the Cameros basin is a $500 \mathrm{~m}$ thick Late Triassic salt sequence (Fig. 3) (Casas Sainz, 1993; Casas-Sainz \& Gil-Imaz, 1998). A pre-rift Jurassic sequence reaching $800 \mathrm{~m}$ in thickness, composed of shallow marine carbonate platform deposits, lies unconformably over both the Triassic salt and the Paleozoic basement (Valladares, 1980; Platt, 1990; Aurell \& Meléndez, 1993; Aurell et al., 2003). The syn-rift sequence begins with 3-6 km of fluvial to lacustrine deposits and rare unconformable marine layers of Late Jurassic to Barremian age (Guiraud \& Séguret, 1985; Platt, 1990; Alonso \& Mas, 1993; Mas et al., 1993, 2011; Quijada et al., 2010; Suárez González et al., 2010). The late Barremian to early Aptian depositional profile is characterized by lithologies typical of 
coastal wetlands with both freshwater and marine influences, grading laterally to alluvial and 222 fluvio-lacustrine deposits (Platt, 1989, 1986). These syn-rift deposits show that the basin was continuously shallow. The syn-rift sequence thins gradually toward the basin's flanks, where it laps onto the pre-rift Jurassic sequence (Fig. 3). An apparent northward migration of the depocenter suggests a slight asymmetry in the basin (Casas-Sainz \& Gil-Imaz, 1998; Guimerà et al., 1995; Mas et al., 1993; Omodeo-Salé et al., 2014, 2017). This northward migration of 227 the depocenter likely indicates that simple shear deformation was concentrated along a 228 detachment fault. This fault was reactivated as a reverse fault during the Pyrenean 229 compression, inducing the northward thrusting of the Cameros basin onto the Ebro flexural 230 basin (Fig. 3) (Omodeo-Salé et al., 2014).

231 The Cameros basin is characterised by (1) the perfect continuity of the pre-rift Jurassic 232 sequence, that is not fragmented along the reactivated detachment (Fig. 3), (2) the absence of 233 normal faulting affecting both basement and cover (Fig. 3) and (3) a lack of significant offset 234 of the top of the basement (Casas-Sainz \& Simón-Gómez, 1992; Casas Sainz, 1993; Casas235 Sainz \& Gil-Imaz, 1998; Casas et al., 2000, 2009; Omodeo-Salé et al., 2014). The basin has 236 therefore been interpreted as an extensional ramp syncline, formed above a décollement in the 237 Late Triassic evaporites rooting at depth on a blind south-dipping extensional ramp or crustal 238 detachment (Mas et al., 1993, 2011; Guimerà et al., 1995; Casas-Sainz \& Gil-Imaz, 1998; 239 Casas et al., 2009; García-Lasanta et al., 2017; Omodeo-Salé et al., 2017). This interpretation 240 explains the northward migration of the syn-rift depocenter and associated edgeward onlap 241 onto the pre-rift deposits, and the development of a synformal rift basin (Fig. 3). The pre-rift 242 Jurassic deposits were stretched by this fault movement, but remained continuous (Casas et 243 al., 2009). The Triassic evaporite layer accommodated most of the shear strain during 244 extension, leaving both cover and basement well preserved. The resulting basinward gliding 
245 of the pre-rift cover was accompanied by thinning of the Triassic evaporites and by salt 246 diapirism (Casas Sainz, 1993; Casas-Sainz \& Gil-Imaz, 1998; Rat et al., 2019).

247 The Cameros syn-rift basin exhibits effects of HT/LP metamorphism in its deepest part, with 248 temperatures that reached around $350-400^{\circ} \mathrm{C}$ (Fig. 3E) (Guiraud \& Séguret, 1985; Golberg et 249 al., 1988; Rat et al., 2019). The rifting stage developed under a high thermal gradient 250 estimated at around $70^{\circ} \mathrm{C} / \mathrm{km}$, assuming a sediment thickness of $8 \mathrm{~km}$ (Mata et al., 2001; Del 251 Río et al., 2009). Toward the basin's northern edge, the palaeogeothermal gradient decreases 252 to $41.5^{\circ} \mathrm{C} / \mathrm{km}$, along with the intensity of the HT/LP metamorphism (Fig. 3F) (Omodeo-Sale 253 et al., 2017). This lower thermal gradient is consistent with an estimated heat flow of 254 approximately 60-65 mW/m² (Omodeo-Salé et al., 2017). The HT/LP metamorphism reached 255 its peak temperature during the early post-rift stage and developed coevally with continental 256 breakup in the North Pyrenean Zone basins (Golberg et al., 1988; Casquet et al., 1992; Casas257 Sainz \& Gil-Imaz, 1998; Mata et al., 2001).

\subsection{Parentis Basin}

The E-W elongated Parentis basin lies between the Landes High (Ferrer et al., 2009) to the south and the Armorican Arc to the north (Lefort \& Agarwal, 1999). This wedge-shaped basin opens westward to the eastern edge of the Bay of Biscay continental margin characterized by exhumed subcontinental mantle at the ocean-continent transition (Fig. 1) (Pinet et al., 1987; Bois \& ECORS Scientific team, 1990; Bois \& Gariel, 1994; Jammes, 2009; Tugend et al., 2014). The south edge of the basin is defined by the north-dipping Ibis fault (Fig. 4; Ferrer et al., 2008). The continental crust of the future Parentis basin underwent several extensional 266 deformations during the Permian to Early Triassic period (Dardel \& Rosset, 1971; Mathieu, 1986; Ferrer et al., 2009; Biteau et al., 2006). Extension was accompanied by the deposition 
1983; Ferrer et al., 2009). The basin was subsequently filled with a $10 \mathrm{~km}$ thick sequence of

270 pre-rift Jurassic and Early Cretaceous syn-rift shallow platform carbonates and terrigenous

271 sediments that rests upon the Late Triassic evaporites (Fig. 4D; Montadert \& Winnock, 1971;

272 Bourrouilh et al., 1995; Bois et al., 1997). Tectonic subsidence occurred in the Parentis basin

273 during a latest Jurassic to Early Albian syn-rift stage, followed by post-rift thermal subsidence

274 during a latest Albian to Late Cretaceous post-rift stage (Brunet, 1994; Ferrer et al., 2008).

275 The Parentis basin is characterised by a hyperextended continental crust with a Moho depth of 276 about $10 \mathrm{~km}$ in the thinnest portion (Bois \& ECORS Scientific team, 1990; Bois, 1992; Ferrer 277 et al., 2008). The overall basin geometry shows gently dipping margins lacking major normal 278 fault scarps (Fig. 4D). The lower continental crust appears to be absent or very thin in the 279 hyperextended domain, while the proximal margins include both upper and lower crust (Fig. 280 4D; Pinet et al., 1987b; Marillier et al., 1988; Tomassino \& Marillier, 1997; Ruiz, 2007). A 281 positive Bouguer gravity anomaly coincides with the hyperextended domain of the Parentis 282 rift basin (Pinet et al., 1987a), which originated during the latest Jurassic to Early Cretaceous 283 rifting affecting the peri-Pyrenean realm (Jammes et al., 2009; Tugend et al., 2015).

284 The ECORS deep seismic profiling project documented the symmetrical synclinal shape of 285 the Parentis basin and the paucity of normal faults in the stretched crust as well as in the 286 proximal rift margins (Fig. 4D) (Pinet et al., 1987b; Bois et al., 1997; Bois \& Courtillot, 287 1988). Once the syn-rift stage was well established, the Parentis basin sedimentary profile 288 became slightly asymmetrical in response to simple shear localization along a crustal 289 detachment during Albian time (Fig. 4D; Pinet et al., 1987a; Jammes, 2009). This evolution 290 stage is comparable to the one identified in the Arzacq basin (Issautier et al., 2020). The southern and northern margins of the rift have been interpreted by various workers as parts of 292 an asymmetric opening system (Jammes et al., 2010a, 2010b, 2010c; Masini et al., 2014; 293 Tugend et al., 2014). However, Pinet et al. (1987b) argued that the location and the geometry 
294 of the thinned zone make it difficult to apply a classical simple shear model to the Parentis 295 basin. They proposed that mantle uplift induced stretching (i.e. active rifting) and ductile flow 296 in the lower crust and consequently a decoupling between the upper and lower crust. This 297 depth-dependent crustal thinning explains the discrepancy between the slight extension at the 298 surface and the substantial thinning of the lower/middle crust (thinning ratio greater than 6) at 299 depth (Fig. 4D). This interpretation implies that the crust beneath the Parentis basin reached 300 the ductile strain regime and was thinned under high-temperature conditions, as was the case 301 in the adjacent North Pyrenean Zone. Finally, according to various authors, the Parentis basin 302 first developed as a latest Jurassic-Aptian symmetrical rift that became asymmetrical when 303 thinning progressively occurred through simple shear concentrated along a ductile crustal 304 shear zone during Albian time. This suggests that the processes responsible for the Parentis 305 basin continental crust thinning bear similarities with the ones defined in the Arzacq and 306 Cameros syn-rift basins.

307 Jammes et al. (2010c) highlighted the major role played by the thick pre-rift salt sequence in 308 decoupling the deformation between the basement and the rest of the Mesozoic sedimentary 309 cover. The southern margin of the Parentis basin underwent gravity-driven cover gliding 310 followed by syn-rift thin-skinned extensional faulting along a décollement plane within the 311 salt (Fig. 4D; Tugend et al., 2014). This process induced the development of syn-rift salt 312 anticlines and welded diapirs affecting the Mesozoic sedimentary pile (Fig. 4D; Mathieu, 313 1986; Mediavilla, 1987; Ferrer et al., 2008). Moreover, Ferrer et al. (2012) reported that salt 314 structures are mainly localised on basin flanks (Fig. 2).

\subsection{Columbrets basin}

316 The Columbrets offshore basin is the southwestern part of the Valencia Trough between Spain 317 and the Balearic Islands (Figs. 1 \& 5A). This ENE-WSW trending basin represents a mildly 
318 inverted and thus exceptionally preserved hyperextended rift of Late Jurassic to Early

319 Cretaceous age (Fig. 5; e.g., Etheve et al., 2018). The pre-rift and syn-rift successions occupy 320 a large-scale synclinal basin with thinned borders, shaped by displacement along extensional 321 detachments (Figs. 5D-E). This domain underwent a polyphase rifting history that spanned 322 three major rifting events. During the Late Permian to Early Triassic, distributed deformation 323 formed an intracontinental rift basin filled by continental deposits (Arche \& López-Gómez, 324 1996; Vargas et al., 2009). This first rifting stage was followed by a Late Triassic-Early 325 Jurassic rifting event related to the opening of the Alpine-Ligurian Tethys (Jiménez-Munt et 326 al., 2010; Frizon de Lamotte et al., 2011; Schettino \& Turco, 2011). The climax of this rifting 327 event was marked by the deposition of a thick layer of evaporites that became a major 328 décollement during subsequent events (Ortí, 1974; Ortí et al., 2017). The Jurassic post-rift 329 sequence is mainly composed of shallow-water limestone (e.g., Roca, 1996). Partial crustal 330 thinning occurred during the first rifting stage (Salas et al., 2001; Nebot \& Guimerà, 2016; 331 Etheve, 2016; Etheve et al., 2018; Roma et al., 2018).

332 The main rifting stage leading to the hyperthinning of the continental crust in the Columbrets 333 basin (Fig. 5D) occurred during the Late Jurassic to early Albian. The syn-rift succession 334 consists of platform carbonate deposits, which grade basinward into deep-water marl and give 335 way locally toward the basin's flanks to fluvial and deltaic deposits (Etheve et al., 2018 and 336 references therein). The platform limestones preserve the record of post-rift thermal 337 subsidence from the middle Albian to the Late Cretaceous (Salas et al., 2001; Nebot \& 338 Guimerà, 2016; Etheve et al., 2018).

339 The Moho depth is $25-30 \mathrm{~km}$ under the margins of the Columbrets basin and only $8-10 \mathrm{~km}$ 340 under the central portion (Fig. 5A; Gallart et al., 1990; Banda \& Santanach, 1992; Dañobeitia 341 et al., 1992; Torné et al., 1996; Vidal et al., 1997; Ayala et al., 2003, 2015; Gomez-Ortiz et 342 al., 2011; Etheve et al., 2018). The thickness of the continental crust reaches a minimum of 
$343 \quad 3.5 \mathrm{~km}$ in the hyperextended domain (Fig. 5D; Etheve et al., 2018), where it coincides with an 344 unusually strong Bouguer gravity anomaly ranging in amplitude between 60 and $80 \mathrm{mGal}$ 345 (Fig. 5B; Ayala et al., 2015). Both features are consistent with the shallowing of the 346 lithosphere-asthenosphere boundary (60-65 km depth) indicated by geoid modelling and 3-D 347 gravity data consistent with extreme crustal thinning (Zeyen \& Fernàndez, 1994; Ayala et al., 348 1996, 2003; Carballo et al., 2015).

349 The Columbrets basin has been interpreted as a salt-detached syn-rift ramp-syncline basin 350 (Roma et al., 2018). The eastern side of the basin features an extensional detachment fault, 351 rooting at depth in the continental crust beneath the hyperextended rift domain (Figs. 5D-E; 352 Etheve et al., 2018) that coincides with the Triassic salt décollement. This detachment is 353 responsible for the overall thin-skinned extensional deformation of the pre-rift sedimentary 354 cover experiencing basinward halokinetic gliding (Etheve et al., 2018). Nevertheless, finite 355 motion along the detachment imaged in seismic reflection profiles is not enough to account 356 for the extreme crustal thinning identified in the basin core and the large discrepancy in 357 thinning ratios between the lower and upper crust (Etheve et al., 2018). In fact, the reflective 358 lower crust becomes thinner toward the axis of the Columbrets basin, where it appears to be 359 either absent or no thicker than 1-2 km (Gallart et al., 1990, 1994; Dañobeitia et al., 1992; 360 Torné et al., 1992; Sàbat et al., 1997; Vidal et al., 1997). These observations highlight the 361 differences in the rheological response of the upper and lower crust to crustal stretching as 362 deduced from the Parentis basin architecture. Etheve et al. (2018) suggested that the lower 363 crust underwent large-scale ductile deformation/boudinage during the Late Jurassic to Early 364 Cretaceous syn-rift stage followed by simple shear along a single crustal detachment at the 365 end of the syn-rift stage. In summary, the evolution of the Columbrets rift system was 366 controlled by shallow decoupling in the Triassic pre-rift evaporites and deep decoupling in the 367 middle crust (Etheve et al., 2018). Thus, its syn-rift evolution shares similarities with the 
behaviour of the Arzacq, Cameros and Parentis basins, which first experienced homogeneous

369 ductile crustal thinning of the lower crustal levels passing to the activation of a shallower crustal detachment.

371

The present-day surface heat flow in the southwestern Valencia Trough is about 65 to 100 $\mathrm{mW} / \mathrm{m}^{2}$ (e.g., Ayala et al., 2015; Carballo et al., 2015). That area also displays the thinnest continental crust section (Banda \& Santanach, 1992; Fernandez et al., 1995; Ayala et al., 2015), demonstrating that a stable high thermal regime was inherited from the Late Jurassic to Cretaceous rifting despite the fact that rifting ended in the Cenozoic.

\subsection{North Pyrenean Zone basins}

In the Pyrenees, late Hercynian (Permian) post-orogenic extension led to the development of continental deposits in endorheic extensional basins (Bixel \& Lucas, 1983, 1987; Bixel, 1984). At the same time, magmatic and granulitic rocks were exhumed all along the North Pyrenean Zone (de Saint Blanquat, 1993; Olivier et al., 2004; Cochelin, 2016; Cochelin et al., 2017; Saspiturry et al., 2019b). A consequence of the Hercynian collapse stage was major thinning of previously hot lithosphere, an important structural inheritance regarding the following Mesozoic stages. Recent studies have proposed that the continental crust was partly thinned before the onset of Early Cretaceous hyperextension. Restorations of IberianEuropean crustal sections across the Mauléon basin (western Pyrenees) and the Ballongue basin (central Pyrenees) show that the Moho was already very shallow ( $20 \mathrm{~km}$ depth) by the end of the Jurassic (Asti et al., 2019; Espurt et al., 2019; Saspiturry et al., 2020a). Thus, the latest Paleozoic thinning stage, as well as the Late Triassic regional extensional stage, should not be neglected when estimating the Cretaceous thinning in the North Pyrenean Zone.

The Triassic deposits of the Western Pyrenees are typical of the German-type succession, ending with a thick evaporite and ophite complex (Curnelle, 1983; Lucas, 1985; Rossi et al., 
2003). The salt unit has played a major role in the Pyrenees, acting as a décollement layer at the base of the Mesozoic sedimentary cover that controlled the deformational style during Early Cretaceous hyperextension (Canérot, 1988, 1989; Canérot \& Lenoble, 1993; James \& Canérot, 1999; Canérot et al., 2005; Jammes et al., 2010b; Lagabrielle et al., 2010, 2020; Duretz et al., 2019). Unlike the previously described basins, the North Pyrenean Zone typically lacks Berriasian and Valanginian deposits (Combes et al., 1998; James, 1998; Canérot, 2008), a witness of the emersion of the area during the earliest Cretaceous. From Barremian to Aptian times, the Iberian and European margins of the North Pyrenean Zone basins were carbonate platforms grading to distal marls toward the basin axis. In summary, the North Pyrenean Zone hyperextended basins are characterised by sedimentary sequences consisting of (1) Late Triassic to Early Jurassic pre-rift evaporites 1-3 km thick (Curnelle, 1983), (2) Jurassic pre-rift carbonate platform rocks $0.5-2 \mathrm{~km}$ thick deposited in a relatively stable tectonic context (Delfaud \& Henry, 1967; Lenoble, 1992; James, 1998), (3) Barremian to Aptian syn-rift carbonates and marls up to $1.6 \mathrm{~km}$ thick (Delfaud \& Villanova, 1967, Arnaud-Vanneau et al., 1979), (4) syn-rift Albian flysch-like deposits (the Black Flysch or "Flysch Ardoisier") 1-5 km thick (Debroas, 1978, 1987, 1990; Boirie, 1981; Boirie \& Souquet, 1982; Fixari, 1984; Roux, 1983; Souquet et al., 1985; Debroas et al., 2010) and (5) post-rift turbidites 2-4 km thick (Casteras, 1971; Henry et al., 1987; Le Pochat et al., 1976; Razin, 1989).

In this section we discuss the reconstructed architecture of the Mauléon and BasqueCantabrian basins, together with that of basins present within the Internal Metamorphic Zone. We show that similarly to the previously described basins, the North Pyrenean Zone basins is affected by a syn-rift stage characterised by pure shear ductile thinning of the lower middle crust. The North Pyrenean Zone basins are characterised by the presence of positive Bouguer gravity anomalies above their inverted hyperextended domain, as evidenced by the Basque- 
417 Cantabrian, Mauléon and Saint-Gaudens anomalies (Fig. 6). These anomalies reflect the 418 presence of subcontinental mantle at shallow depth that was exhumed during the climax of the 419 Mesozoic extension. With the exception of the Columbrets basin, the North Pyrenean Zone 420 rift basins record continental breakup and mantle exhumation from the latest Albian to Early 421 Cenomanian (breakup sequence, sensu Soares et al., 2012).

\subsubsection{Mauléon basin}

The Mauléon basin, located south of the Arzacq basin (Figs. 1 \& 7), coincides with a strong 424 positive gravity anomaly centred upon the basin axis (Figs. 6 \& 7A; Gottis, 1972; Boillot et al., 1973). First interpreted as lower crustal material (Grandjean, 1994; Vacher \& Souriau, 2001; Pedreira et al., 2007), the anomaly is currently attributed to the presence at shallow depth $(\sim 10 \mathrm{~km})$ of a dome of subcontinental mantle (Fig. 7B; Casas et al., 1997; Jammes et al., 2010a). This interpretation has gained support from recent work documenting P-wave velocities of $\sim 7.3 \mathrm{~km} / \mathrm{s}$ in this deep material (Fig. 7B; Wang et al., 2016; Chevrot et al., 2018). Above the mantle dome, the thickness of the crust is assumed to be roughly $5 \mathrm{~km}$ (Fig. 7B). Mantle exhumation apparently occurred during Cretaceous hyperextension, when the

432 Mauléon basin developed as a hyperextended rift (Jammes et al., 2009; Lagabrielle et al., 433 2010; Masini et al., 2014; Tugend et al., 2014; Corre et al., 2016; Teixell et al., 2016; 434 Lagabrielle et al., 2019a; Labaume \& Teixell, 2020). The basin was inverted during Eocene 435 shortening and is a pop-up structure at present, bordered to the north and south by conjugate 436 thrusts (Fig. 7B; Saspiturry et al., 2020a).

437 The Mauléon basin began as a symmetric syn-rift basin that subsided in response to pure 438 shear ductile thinning of the lower/middle crust during the Early Cretaceous (Saspiturry et al., 439 2019a) (Fig. 7E). Its structural style changed from Albian to early Cenomanian time, leading 440 to asymmetric basin morphology and sedimentary facies distribution. Gravity-flow 441 conglomerates accumulated at the foot of the Iberian margin slope, forming the Mendibelza 
442 fan conglomerates (Boirie, 1981; Fixari, 1984; Souquet et al., 1985), in response to activity on 443 steep north-dipping normal faults (South Arbailles and North Arbailles faults; Saspiturry et 444 al., 2019a). These rocks originated in fan deltas reworking freshly uplifted Paleozoic 445 substratum. Restoration of syn-rift geometries indicates that the Iberian substratum was tilted $44630^{\circ}$ toward the north in Albian time (Saspiturry et al., 2019a). This implies a thickening of 447 syn-rift deposits to the north toward the steep south-dipping Saint-Palais fault, where the 448 conglomerates reach a maximum thickness of around $5 \mathrm{~km}$ (Fig. 7). This fault separated the 449 marls of the central basin from the European proximal margin to the north, where a carbonate 450 platform developed (Saspiturry et al., 2019a). The gentle southward slope of the European 451 margin contrasts with the steep northward slope of the Iberian margin. This geometry points 452 to the Saint-Palais fault as a major normal fault that was responsible for the change to 453 asymmetric basin margins during Albian to early Cenomanian time. In this scheme, the steep north-dipping slope of the Iberian margin can be interpreted as a rollover structure in the hanging-wall of the Saint-Palais fault. The rollover structure is also accommodated by minor north-dipping normal faults that propagated toward the south.

457 Facies distribution significantly changed from the mid-Cenomanian to the late Santonian in 458 the Mauléon basin as shallow carbonate platforms developed on the Iberian and European 459 margins (Souquet, 1967; Alhamawi, 1992; Ternet et al., 2004; Serrano et al., 2006). On the 460 European side, the transition from platform to basin coincided with the steep south-dipping 461 South Grand Rieu fault (Fig. 7). The Iberian carbonate platform graded northward rather 462 abruptly to deep-sea calcareous breccias at the site of the Lakhoura normal fault, which 463 appears to have acted as a significant northward detachment during mid-Cenomanian times. 464 This detachment, responsible for a southward tilt of the Iberian basement, crosscuts the lower 465 part of the older Saint-Palais structure, which was inactive at that time. Thus, the Mauléon 466 basin was affected by ductile pure shear thinning of the lower/middle crust from the 
Barremian to the Aptian, followed by Albian simple shear concentrated along two major

468 crustal detachments: (1) the south-verging Saint-Palais fault accommodating the thinning of 469 the European margin and (2) the north-verging Lakhoura detachment crosscutting the Saint470 Palais fault (Fig. 7C3). Along strike, the Mauléon basin was affected by continental breakup 471 from the latest Albian to the Early Cenomanian (Fig. 7D) as evidenced by the presence of 472 subcontinental mantle clasts into the latest Albian to Early Cenomanian Urdach breccias 473 (Roux, 1983; Duée et al., 1984; Fortané et al., 1986; Debroas et al., 2010) as well as by the 474 formation of ophicalcites at the surface of the denudated mantle (Jammes et al., 2009; 475 Lagabrielle et al., 2010, 2019a; Debroas et al., 2010).

476 Rifting and continental breakup in the Mauléon basin developed, from the Early Cretaceous to 477 the mid-Cenomanian (Fig. 7E), under a high geothermal gradient, as indicated by (1) Raman 478 spectroscopy of carbon materials (RSCM) showing peak temperatures consistent with a 479 gradient of $60-75^{\circ} \mathrm{C} / \mathrm{km}$ (Corre, 2017; Saspiturry, 2019; Saspiturry et al., 2020b), (2) detrital 480 zircon fission-track data indicating a $80^{\circ} \mathrm{C} / \mathrm{km}$ gradient (Vacherat et al., 2014) and (3) (U-Th$481 \mathrm{Sm}) / \mathrm{He}$ thermochronology data indicating a $80-100^{\circ} \mathrm{C} / \mathrm{km}$ gradient (Hart et al., 2017). 482 Numerical thermal models suggest that the base of the hyperextended domain had a mantle 483 heat flow of $100 \mathrm{~mW} / \mathrm{m}^{2}$ and a maximum temperature of $600^{\circ} \mathrm{C}$ during continental breakup 484 (Saspiturry, 2019; Saspiturry et al., 2020b). Vitrinite reflectance values from the Mauléon 485 basin also weigh in favour of HT/LP syn-rift metamorphism (Lescoutre, 2019; Lescoutre et 486 al., 2019). It should be noted that the peak temperature was reached in the lower part of the 487 basin during the post-rift period (Vacherat et al., 2014; Saspiturry, 2019), similar to the 488 Cameros basin. Due to Pyrenean thrusting, a detached slice of mantle rock crops out in the 489 eastern part of the basin (Urdach area). In that location, crustal material in contact with the 490 Urdach lherzolites shows ductile shearing, suggesting that the upper/middle crust was 491 extruded laterally from the basin axis at temperatures between $350^{\circ} \mathrm{C}$ and $450^{\circ} \mathrm{C}$ (Asti et al., 
2019). Hydrothermal fluid circulation sheds light on the ductile shearing of the Mauléon basin pre-rift cover during continental breakup at $~ 94$ Ma (Incerpi et al., 2020). The thermal regime of the Mauléon basin from the end of the syn-rift stage (Albian, Fig. 7E) to the breakup sequence (latest Albian to Early Cenomanian; Fig. 7E) attests a ductilely stretched sedimentary cover and crystalline basement.

\subsubsection{Basque-Cantabrian basin}

The Basque-Cantabrian basin records a similar Mesozoic history as the North Pyrenean Zone rift basins, although it developed to the eastern termination and south of the Pyrenean Axial Zone (AZ in Fig. 1). The rift axis is characterised by a succession of Upper Jurassic and Cretaceous sediments around 8-10 km thick with interlayered basic volcanic rocks of Aptian to Santonian age (Figs. 8A-B; Azambre \& Rossy, 1976; Rat et al., 1983; Rat, 1988; García Mondéjar et al., 1996; Castañares et al., 1997; Castañares \& Robles, 2004). The lithosphere is extremely thin in the western central part of the basin, as suggested by a positive Bouguer anomaly recorded in the Biscay Synclinorium (Fig. 6; Pedreira et al., 2007) that is interpreted as the consequence of lithospheric mantle exhumed at shallow depth (Figs. 8A-B; Pedrera et al., 2017, 2020; Garcia-Senz et al., 2019). Field observations and seismic interpretations indicate that the Basque-Cantabrian basin has an overall symmetric shape characterised by brittle deformation on its flanks and ductile deformation on its axis (DeFelipe et al., 2017; Pedrera et al., 2017; Ducoux et al., 2019).

The basin continental crust was stretched during the Early Cretaceous rifting stage. Locally, mantle denudation occurred during early Cenomanian continental breakup as revealed by the presence of a strongly weathered mantle fragment near the inverted Leiza major detachment fault (Mendia \& Ibarguchi, 1991; DeFelipe et al., 2017; Ducoux, 2017; Ducoux et al., 2019). Hyperextension was also recorded by the development of Cretaceous HT/LP metamorphism (Golberg \& Leyreloup, 1990; Cuevas \& Tubia, 1999). Mineral assemblages and RSCM data 
517 from the Nappes des Marbres, which represents the inverted eastern part of the Basque-

518 Cantabrian basin, indicate that temperature in the pre-rift sedimentary cover locally reached

519 500-600 ${ }^{\circ} \mathrm{C}$ during hyperextension (Figs. 8C-D; Lamare, 1936; Martínez-Torres, 1989;

520 Mendia \& Ibarguchi, 1991; Ducoux et al., 2019). Thus, the felsic crust and its sedimentary

521 cover underwent ductile stretching during the Albian syn-rift stage and Cenomanian

522 continental breakup. Interpretations of geophysical data have shown that decoupling between

523 basement and cover rocks occurred in low-strength Triassic evaporites and mudstones and

524 induced coeval formation of cover gliding, mini-basins, turtle salt anticlines, expulsion

525 rollovers, and salt diapirs in the cover strata (Fig. 8; Pedrera et al., 2017, Ducoux et al., 2019;

526 Cámara, 2020). The association of exhumed mantle along the Leiza fault with rift and post-

527 rift structural geometries suggests that a major south-dipping ramp-flat-ramp extensional

528 detachment was active from Albian to early Cenomanian time (Lagabrielle et al., 2020).

\subsubsection{Internal Metamorphic Zone basins}

530 The central and eastern portions of the North Pyrenean Zone include a narrow Internal

531 Metamorphic Zone along their southern borders (Fig. 1). They consist of a east-west-trending

532 stretched zone of Variscan basement and pre-rift to syn-rift metamorphic rocks (Casteras,

533 1933; Mattauer, 1968; Choukroune, 1974) with several outcrops of subcontinental mantle

534 rocks (Monchoux, 1970; Choukroune \& Mattauer, 1978; Fabriès et al., 1991, 1998;

535 Lagabrielle et al., 2010). Recent studies have shown that the Internal Metamorphic Zone is an

536 inverted domain of continental crust that was hyperextended during Early Cretaceous rifting

537 (Lagabrielle \& Bodinier, 2008; Lagabrielle et al., 2010; Clerc \& Lagabrielle, 2014; Clerc et

538 al., 2014, 2015; de Saint Blanquat et al., 2016; Teixell et al., 2018; Dielforder et al., 2019;

539 Espurt et al., 2019; Garcia-Senz et al., 2019). In the central Pyrenees, the Internal

540 Metamorphic Zone coincides with the Saint-Gaudens positive Bouguer anomaly (Fig. 9A)

541 and corresponds to the inverted Early Cenomanian continental breakup domain (Figs. 9B-C). 
542 It has been shown that the whole continental crust of the North Pyrenean Zone was affected

543 by large-scale ductile boudinage during Early Cretaceous hyperextension, with E-W trending 544 rift basins exhibiting a relatively symmetrical profile (Clerc et al., 2015; Lagabrielle et al., 545 2020). The presence of a thick pre-rift salt layer led to basinward gliding of the overlying 546 Jurassic cover during hyperextension (Lagabrielle et al., 2010; Clerc \& Lagabrielle, 2014; 547 Clerc et al., 2015; Duretz et al., 2019; Lagabrielle et al., 2020).

548 Evidence of HT/LP metamorphism has been reported along the entire North Pyrenean Zone 549 (Ravier, 1957; Albarède \& Michard-Vitrac, 1978a, 1978b; Golberg et al., 1988; Golberg \& 550 Maluski, 1988; Golberg \& Leyreloup, 1990; Clerc et al., 2015). This metamorphism resulted 551 from Early Cretaceous continental-crust thinning and an associated increase in thermal 552 gradient and burial (Choukroune \& Mattauer, 1978; Vielzeuf \& Kornprobst, 1984; Debroas, 1990; Clerc et al., 2015). RSCM peak temperatures reached $400-600^{\circ} \mathrm{C}$ in the marbles of the 554 Internal Metamorphic Zone, where some of the highest temperatures were recorded close to 555 exhumed mantle outcrops (Fig. 9D; Clerc, 2012; Clerc et al., 2015; Boulvais, 2016; Chelalou 556 et al., 2016; Lagabrielle et al., 2016; Ducoux, 2017). During the Albian syn-rift stage and the 557 Early Cenomanian breakup event, the crust was homogeneously and ductilely stretched in the 558 hyperextended domain, while detachment faults at the transition between the mantle and the 559 crust/sedimentary cover accommodated the thinning of the whole system (Lagabrielle et al., 560 2019a). Likewise, mineral assemblages indicate that maximum temperatures of $550-650^{\circ} \mathrm{C}$ 561 and pressures of 3-4 kbar were reached locally (Bernus-Maury, 1984; Golberg \& Leyreloup, 562 1990; Vauchez et al., 2013). Previous authors have established that this metamorphic event 563 was linked to high syn-rift geothermal gradients (Dauteuil \& Ricou, 1989; Golberg \& 564 Leyreloup, 1990; Clerc et al., 2015; Lagabrielle et al., 2016). Finally, these data collectively 565 indicate that the Jurassic to Early Cretaceous metacarbonate cover forming the current 566 Internal Metamorphic Zone corresponds to pre-rift to basal syn-rift sediments located in the 
deepest part of the former North Pyrenean Zone basin, which was also characterised by a thin continental crust.

The WNW-ESE trending Lourdes and Saint-Gaudens positive Bouguer anomalies coincide

570 with the maximum thickness of the Albian syn-rift turbidites (Figs. 9A-B; Casas et al., 1997).

571 Espurt et al. (2019) interpreted the Saint-Gaudens anomaly as a body of allochthonous mantle

572 pushed northward onto the European margin on the North Pyrenean Frontal Thrust. It 573 corresponds to an allochthonous body of subcontinental mantle that was previously exhumed 574 during Early Cretaceous time (Fig. 9B).

\section{Discussion: Tectono-sedimentary evolution of smooth-slope extensional} basins

\subsection{Syn-rift}

\subsubsection{Pure-shear dominated thinning}

All the basins reviewed in this work are characterised by a strong heterogeneous structural pattern inherited from the Late Carboniferous to Triassic rifting events related to the collapse of the Variscan belt and the breakup of Pangea. These events ended with the deposition of 1-3 km thick Late Triassic to Early Jurassic salt deposits. Thus, Mesozoic hyperextension initiated within a continental crust that was previously thinned to less than $30 \mathrm{~km}$ thick (Fig. 10A). Unfortunately, the precise thickness of the crust at the end of the Triassic remains undetermined. The Late Jurassic to Early Cretaceous syn-rift stage was driven by distributed deformation characterised by the lateral extraction of the lower/middle crust (Fig. 10B). During this stage, thinning of the lower/middle crust triggered progressive subsidence. Our review shows that homogeneous subsidence was partly balanced by the production of syn-rift carbonates in most of the studied basins. The result is a relatively smooth basin floor profile characterised by carbonate platform deposits with marls in a central trough. During this early 
stage, the basin was symmetric and marked by edgeward onlap of the syn-rift deposits (Fig.

592 10B). The pre-rift cover was efficiently decoupled from its substratum thanks to the thick 593 layer of Keuper evaporites at its base. This rheological layering and the progressive sinking of 594 the central part of the rift system eventually led to the breakup of the pre-rift lid on the 595 external margins of the basin. This resulted in a large-scale pre-rift cover which remained in 596 the central part of the extensional system throughout the whole basin lifetime, while the 597 continental crust was progressively thinned below it (Fig. 10B and C). In contrast to all other 598 reviewed basins, the Tartas basin exemplifies this syn-rift stage since continental crust 599 thinning was not followed by the activation of extensional detachments, allowing the basin 600 floor profile to remain symmetric. During this first rift regime, the upper crust might have 601 been affected by very minor brittle deformation beneath the salt décollement level that led to 602 superficial salt diapirism affecting the pre-rift to syn-rift sedimentary cover (Fig. 10B), as 603 evidenced in the Arzacq (Issautier et al., 2020), Parentis (Ferrer et al., 2012), Columbrets 604 (Etheve et al., 2018), and Mauléon (Canérot et al., 2005) basins during Late Jurassic to Aptian 605 time. However, during this syn-rift stage, continental crustal thinning was mainly 606 accommodated by distributed ductile thinning within the lower/middle continental crust. This 607 process was first suggested in the case of the Parentis basin (Pinet et al., 1987a). It was then 608 put forward by Clerc and Lagabrielle (2014) in their interpretation of the architecture of the 609 eastern North Pyrenean Zone basins and used by Corre et al. (2016) in the reconstruction of 610 the eastern Mauléon basin border. It has more recently been applied to the central Mauléon 611 basin (Saspiturry et al., 2019a; Asti et al., 2019), Arzacq basin (Issautier et al., 2020) and 612 Columbrets basin (Etheve et al., 2018). It consists of a distributed thinning stage in which the 613 lower/middle crust was homogeneously and symmetrically thinned without major brittle 614 deformation of the upper crust. Interpretation of seismic profiles sheds light on the wide 615 discrepancy in thinning ratios between the lower and upper crust in the Columbrets (Etheve et 
616 al., 2018) and Parentis (Pinet et al., 1987a) basins as they were slightly inverted. Such a

617 discrepancy in the amount of continental thinning has been numerically modelled and defined

618 as depth-dependent continental crust thinning (Huismans \& Beaumont, 2008, 2011, 2014).

619 This pure shear dominated thinning stage is applicable to all the North Pyrenean Zone basins

620 since (1) their sedimentary profile was symmetric throughout the Barremian to Aptian 621 beginning of the syn-rift stage and (2) they do not record exhumation of the lower crust 622 during Mesozoic hyperextension in their central part (see section 2.5 for more details).

\subsubsection{Simple shear dominated thinning}

624 As thinning of the lower/middle crust continued, isostatic subsidence occurred in the centre of 625 the basin. The early smooth synclinal-shape basin progressively deepened, triggering steepening of pre-to- syn-rift sequences. Deformation became localised and a simple shear regime initiated along a crustal detachment connecting upward to the Late Triassic pre-rift salt

628 décollement. With the progression of extension, the pre-rift sequence was progressively 629 dissected in several large-scale boudins and turtle structures separated by intervening salt 630 diapirs (Fig. 10C and D). The top basement surface is steeper in the basin flanks than in the 631 basin core, therefore portions of the pre-rift cover may undergone gravity-driven gliding 632 leading to local syn-extensional thrusting (layer-parallel shortening). From a general point of 633 view, gliding was controlled by thickness variations of the sedimentary pile that cause 634 differential loading on the salt layer (Lundin, 1992; Liro \& Coen, 1995; Rouby et al., 2002) 635 and basinward tilting of the proximal margin (Cobbold \& Szatmari, 1991; Demercian et al., 636 1993; Gaullier et al., 1993; Fort et al., 2004a, 2004b). The gravity gliding unroofed the 637 basement of the proximal rift margin. As the pre-rift and syn-rift sequences glided along the 638 décollement, salt was expelled both marginward and basinward as well as upward by 639 buoyancy. Thus, in the reviewed basins, halokinesis led to (1) the development of salt640 detachment synclines, salt rollovers or diapirs affecting and controlling syn-rift depocentres 
641 and (2) the denudation of the proximal margin basement that was subsequently overlain by

642 syn-rift sediments. This scenario is reported from most of the studied basins.

643 (1) In the Arzacq basin, the southern margin recorded northward cover gliding (Fig. 2;

644 Issautier et al., 2020).

645 (2) In the Parentis basin, major diapirism (Pelican borehole, Fig. 4D; Ferrer et al., 2008, 2009, 646 2012) and denudation of its southern margin basement (Fig. 4D: Jammes, 2019) were 647 documented.

648 (3) In the Columbrets basin, the SE margin basement was denudated (Etheve et al., 2018).

649 (4) In the Mauléon basin, the proximal margin basement was locally denudated on both edges 650 of the rift (Fig. 7C3 \& 7D; Teixell et al., 2016; Saspiturry et al., 2020a).

651 (5) In the Basque-Cantabrian basin, the prerift cover was removed from its proximal margins 652 (Fig 8A; Pedrera et al., 2017).

653 (6) In the Internal Metamorphic Zone, the pre-rift allochthonous cover remained in its central 654 part (Fig. 9C-D; Espurt et al., 2019).

655 Denudation of the basement proximal margin has also appeared in thermo-mechanical 656 numerical models of lithospheric-scale extension that integrate recent data collected along the 657 North Pyrenean Zone basins (Duretz et al., 2019). This process resulted in the formation of 658 syn-gliding wedge-shaped sedimentary geometries and syn-rift sequence depocenter 659 migration, as seen in (a) the Arzacq and Parentis basins, which display southward syn-rift 660 depocenter migration (Fig. 2 and 4D; Jammes, 2009; Issautier et al., 2020), and (b) the 661 Cameros, Columbrets and Mauléon basins which display northward, north-westward and 662 northward syn-rift depocenter migration, respectively (Figs. 3F, 4D and 7C2-C3; Omodeo663 Salé et al., 2014; Etheve et al., 2018; Saspiturry et al., 2020a). In the Mauléon basin, the 
664 increasing northward slope-deepening of the Iberian margin is interpreted as a rollover effect

665 linked to the Saint-Palais detachment. Increasing tilting of the Iberian margin led to cover 666 gliding, immediately followed by the accumulation of deep basin gravity deposits. These 667 latter consist of reworked sediment from rafts of the pre-rift sedimentary cover and the freshly 668 exposed proximal margin basement (Teixell et al., 2016; Saspiturry et al., 2019a; Labaume \& 669 Teixell, 2020). A similar evolution cannot be clearly reconstructed for the Basque-Cantabrian 670 and Internal Metamorphic Zone basins, which experienced severe inversion during the 671 compressional stages of the Pyrenean orogeny (e.g. Pedrera et al., 2017, Fig. 8A; Espurt et al., 672 2019, Fig. 9C). In contrast to the Tartas basin, which did not reach the second syn-rift 673 extensional stage, all the other basins became asymmetric, as evidenced by shifts of the basin 674 depocenter.

675 Seismic profiles display clear images of crustal detachments in the Parentis (Fig. 4D; Jammes, 676 2009; Jammes et al., 2010c; Tugend et al., 2014) and Columbrets (Figs. 5D \& 5E; Etheve et 677 al., 2018) basins. Both basins exhibit an asymmetric outline associated with a very thin crust 678 in their axial regions. This sheds light on the fact that important crustal thinning was partly 679 accommodated by simple shear deformation along the imaged detachments (Fig. 2B; Issautier 680 et al., 2020). In the Arzacq and Cameros basins, detachment faults have not been imaged but 681 only inferred, although both basins evolved with cover gliding and depocenter migration 682 during the syn-rift stage. For instance, the northern thrust edging the Cameros basin has been 683 interpreted as a reactivated syn-rift southward deepening ramp-flat structure corresponding to 684 an extensional detachment (Figs. 5E-F; Omodeo-Salé et al., 2014). Although the Arzacq, 685 Cameros, Parentis and Columbrets basins did not record continental breakup like the North 686 Pyrenean basins, crustal thinning was fairly advanced, developing under warm thermal 687 conditions during the simple shear stage. Indeed, mature mantle exhumation is evidenced by a 688 positive Bouguer anomaly and a current shallow Moho depth in the Parentis (Figs. 4A \& 4D; 
Jammes, 2009) and Columbrets basins (Figs. 5A-D; Ayala et al., 2015; Etheve et al., 2018).

690 Due to progressive burial and continental crust thinning, the sedimentary cover in the centre

691 of some smooth-slope basins experienced warm thermal regimes as typically shown by the

692 HT/LP metamorphism of the North Pyrenean Basins (more than $400^{\circ} \mathrm{C}$ ). This is also

693 documented in the Cameros basin by mineralogical analysis, thermochronology and fluid

694 inclusion studies (Fig. 3F; Rat et al., 2019), as well as in the Columbrets basin by an elevated 695 mantle heat flow of around $100 \mathrm{~mW} / \mathrm{m}^{2}$ (Ayala et al., 2015; Carballo et al., 2015).

\subsection{Breakup stage}

697

698

699

700

701

702

703

704

705

706

707

708

709

710

711

712

The North Pyrenean Basins first underwent significant pure shear ductile thinning of the lower/middle crust throughout the Barremian to Aptian, followed by simple shear localization on detachment faults during the Albian (Saspiturry et al., 2019a). In concept, continental breakup occurs once the sedimentary cover is removed from the proximal margins and the lower crust fully withdrawn from the basin centre (Fig. 10D). This results in the development of brittle deformation on the basin flanks and the formation of tilted basement blocks devoid of sedimentary cover, while the central hyperextended domain records dominantly ductile thinning and mantle exhumation (Fig. 10D). As previously shown by Soares et al. (2012), while the upper continental crust deforms in a brittle manner in the hyperextended domain during dominantly pure-shear thinning, the deformation regime switches during dominantly simple-shear thinning and subsequent mantle exhumation. As the lower and middle crust is removed from the basin centre during the syn-rift sequence, the isotherms rise under the most highly extended parts of the rift. The $300^{\circ} \mathrm{C}$ to $500^{\circ} \mathrm{C}$ isotherms can be traced above the top of the Variscan basement and overlying pre-rift and syn-rift sediments. This implies that large volumes of the basement and cover were in a ductile regime during this stage (Fig. 10D). Thus, during the breakup sequence, thinning of the crust is first controlled by the elevation of the thermal conditions in relation with mantle exhumation. An additional parameter triggering 
714 temperature elevation is the progressive burial of the continental crust under a thick

715 sedimentary cover that accumulates in the basin during the syn-rift stage. Both causes 716 significantly increase the temperature at the base of the basin. This process has also been 717 demonstrated by numerical modelling of the North Pyrenean Zone basins (Duretz et al., 718 2019). In the hyperextended domain, extension is localised along a ductile shear zone at the 719 transition between mantle and continental crust/sedimentary cover.

720 Our review highlights important characteristics of the thinning processes in the most evolved 721 basins. We confirm that the conditions of HT/LP metamorphism evident along the 722 hyperextended domains of the North Pyrenean basins account for the ductile behaviour of the 723 crust. The climax of this thermal metamorphism occurred during continental breakup 724 (Albarède \& Michard-Vitrac, 1978a; Montigny et al., 1986; Golberg et al., 1986; Golberg \& Maluski, 1988; Thiébaut et al., 1992). The peak temperature reached in the Jurassic to Albian sedimentary cover varies between $500^{\circ}$ and $600^{\circ} \mathrm{C}$, as documented in various places: (1) the Mauléon basin (Figs. 7C4-D; Corre, 2017; Saspiturry, 2019), (2) the Nappes des Marbres in the Basque-Cantabrian basin (Fig. 8D; Lamare, 1936; Martínez-Torrez, 1989; Mendia \& Ibarguchi, 1991; Ducoux, 2017; Ducoux et al., 2019) and (3) the Internal Metamorphic Zone 730 basins in the central and eastern Pyrenees (Fig. 9D; Bernus-Maury, 1984; Golberg \& 731 Leyreloup, 1990; Azambre et al., 1992; Clerc, 2012; Vauchez et al., 2013; Clerc et al., 2015; 732 Chelalou et al., 2016).

733 The Internal Metamorphic Zone and the Nappes des Marbres have been interpreted as the 734 inverted base of the North Pyrenean hyperextended rift domain (Clerc, 2012; Clerc \& 735 Lagabrielle, 2014; Clerc et al., 2015; Lagabrielle et al., 2016; Ducoux, 2017). In these settings, continental crust thinning resulted in a high geothermal gradient estimated at around 60- $100^{\circ} \mathrm{C} / \mathrm{km}$ in the Mauléon basin (Vacherat et al., 2014; Corre, 2017; Hart et al., 2017; 738 Saspiturry, 2019). The maximum temperature reached in the sedimentary cover increased 
from the margins to the hyperextended domain. Thus, the thermal gradient increased together

740 with the thickness of the sedimentary pile (Saspiturry, 2019). Numerical thermal modelling

741 has shown that this thermal gradient was associated, in the Mauléon basin, with an elevated

742 mantle heat flow of around $100 \mathrm{~mW} / \mathrm{m}^{2}$ (Saspiturry, 2019). The basinward gliding of the pre-

743 rift cover contributed significantly to the burial and thus to the peak temperature increase at

744 the base of the hyperextended domain.

745 The coupled effects of heating by mantle exhumation and burial under the thick pre-rift (salt 746 tectonic) to syn-rift sedimentary sequence prevented crustal normal faults from propagating 747 into the hyperextended domain, as evidenced in the Nappes des Marbres (Fig. 8D; Ducoux et 748 al., 2019) and the Internal Metamorphic Zone (Fig. 9D; Espurt et al., 2019). Thinning of both 749 the Variscan basement and the allochthonous sedimentary pile occurred in the hyperextended 750 domain within a thick zone of dominantly ductile shear (Lagabrielle et al., 2019a). This 751 process led to the formation of large-scale boudins and lenses of continental crust and 752 strongly sheared metasedimentary rocks (Clerc \& Lagabrielle, 2014; Clerc et al., 2015b; 753 Corre et al., 2016; Asti et al., 2019; Duretz et al., 2019; Lagabrielle et al., 2019a). These 754 mature basins then took the shape of typical pseudo-symmetric hyperextended rift basins; 755 their margins were affected by brittle normal faulting and their centres were dominated by 756 ductile stretching as observed along the most evolved smooth-slope basins of the North 757 Pyrenean Zone. As shown by the presence of clasts of mantle rocks in the Cretaceous 758 turbidite breakup sequence of the Urdach area, these basins underwent local denudation of 759 subcontinental mantle thanks to motion along a major detachment during the Late Albian to 760 Early Cenomanian continental breakup (Roux, 1983; Duée et al., 1984; Fortané et al., 1986; 761 Jammes et al., 2009; Debroas et al., 2010; Lagabrielle et al., 2010, 2019a, b). Although the 762 Mauléon basin displays clasts of mantle rocks reworked in its breakup sequence sensu Soares 763 et al. (2012), it underwent heterogeneous amounts of mantle denudation and seems to show a 
764 less advanced stage of continental breakup than the Basque-Cantabrian and Internal 765 Metamorphic Zone basins. According to Saspiturry et al. (2019a, 2020a), the amount of 766 mantle denudation under the Mauléon basin varied along strike as a consequence of Permian 767 inheritance along N20 ${ }^{\circ}$ transverse structures (Fig. 7C3; Saspiturry et al., 2019b). It was 768 maximal in the eastern part (Urdach) but almost nonexistent in its western part (Fig. 7D; 769 Teixell et al., 2016; Labaume \& Teixell, 2020). In addition, the Internal Metamorphic Zone 770 basin displayed a more advanced breakup sequence than the Basque-Cantabrian basin as 771 evidenced by the widths of exhumed mantle along two restored crustal-balanced cross772 sections, which are 45 km (Fig. 9C; Espurt et al., 2019) and 15 km (Fig. 8A; Pedrera et al., 773 2017) long, respectively. The Bilbao, Mauléon and Saint-Gaudens positive Bouguer 774 anomalies (Fig. 6) represent the remains of continental breakup stages now buried at depth, as 775 they correspond to major pieces of mantle exhumed during the latest Albian to Early 776 Cenomanian breakup sequence and more recently inverted during the Pyrenean orogeny 777 (Figs. 7A-B, 8A-B \& 9A-B).

778 Based on the observations listed in this section, we may conclude that the reviewed smooth779 slope extensional basins represent different degrees of hyperextension that occurred along the 780 Iberia-Eurasia plate boundary during the Cretaceous drift of Iberia. We thus propose to rank 781 these basins from least mature to most mature as follows: (1) Tartas, (2) Arzacq/Cameros, (3) 782 Parentis/Columbrets, (4) Mauléon, (5) Basque-Cantabrian and (6) Internal Metamorphic Zone 783 (Fig. 11). This ranking indicates that as the amount of extension increases in these basins, the 784 intensity of various fundamental processes also increases. These processes are lower/middle 785 crust lateral extraction, thermal gradient and heat flow, HT/LP metamorphism, ductile 786 thinning of the crust and its sedimentary cover, relative gliding of the pre-rift cover and 787 mantle exhumation. 
A major consequence of all these processes is the formation of a succession of basins with

789 smooth basement slopes, which differ significantly from rift basins controlled by dominantly normal faulting that affects both their borders and centres. These smooth-slope basins were the locus of gentle, homogeneous subsidence that led to the deposition of syn-rift flysch-like

792 sediments a few kilometers thick. Therefore the response of the smooth-slope basins to 793 extensional stress was the accumulation of sediments that in turn increased the thermal burial 794 effect in the basin centres. Such burial appears to have been a key factor in the syn-rift 795 evolution of smooth-slope basins, along with parameters that were critical earlier at the 796 initiation of rifting, such as the Variscan-Triassic inheritance of thin crust (Asti et al., 2019) 797 and the presence of a very thick (average $2 \mathrm{~km}$ ) layer of evaporites and shale of the Keuper 798 group that allowed the decoupling of the pre-rift cover and its stagnation within the centre of 799 the studied basins (Lagabrielle et al., 2020). Syn-rift deposits of mature smooth-slope basins 800 are well known in the North Pyrenean Zone as the "Flysch Noir" group (Souquet et al., 1985; 801 Debroas et al., 1990). Pioneer authors such as Ravier (1959) have shown that this sequence 802 locally experienced HT/LP metamorphism and deduced from microstructural analysis that a 803 large part of this evolution was static and necessarily linked to passive burial in the Flysch 804 Noir basins. These authors clearly showed that the thermal pulse did not affect the 805 Cenomanian sediments, leading to the concept of a "phase ante-cénomanienne" (e.g. Casteras, 806 1933). In contrast, further studies pointed to the synkinematic character of some HT/LP 807 mineral assemblages and claimed that Pyrenean metamorphism was linked to the orogenic 808 evolution of the belt (e.g. Choukroune, 1976). Later detailed studies revisited the link between 809 thermal metamorphism and the opening of the North Pyrenean basins (e.g. Golberg \& 810 Leyreloup, 1990). However, these studies did not consider the role of sedimentary burial. 811 Therefore, in this review, we note the existence of pioneer works that despite the rudimentary 
812 geological knowledge of the time deduced 60 years ago that sediment burial was a key factor

813 in the thermal evolution of the basins at the Iberia-Eurasia plate boundary.

\section{Comparison of smooth-slope type basins with Atlantic type margins: West}

\section{Iberia and Bay of Biscay margins}

\subsection{Review of the timing of the main Mesozoic events and unconformities}

817 In this section we address the timing of formation of the syn-rift, breakup, post-rift and

818 drifting sequences in the reviewed basins as well as in the adjacent Northwest Iberia and Bay 819 of Biscay margins (Fig. 12). As a reminder, the syn-rift, breakup, post-rift and drifting 820 sedimentary sequences record respectively crustal thinning, mantle denudation, post-rift 821 thermal cooling and oceanic spreading (e.g. Alves et al., 2009, 2020; Soares et al., 2012; 822 Alves \& Cunha, 2018). These sequences are delimited by major unconformities 823 corresponding (from bottom to top) to the base syn-rift unconformity (BSU; base of syn-rift 824 sequence), the lithospheric breakup surface (LBS; base of the breakup sequence) and the base 825 post-rift unconformity (BPU; base of the post-rift sequence) as defined by Soares et al. (2012) 826 and Alves and Cunha (2018).

827 All the reviewed basins as well as the West Iberia and Bay of Biscay margins are 828 characterised by the onset of Mesozoic rifting between the Late Jurassic and earliest 829 Cretaceous as they are all related to Iberia plate motion associated with the North Atlantic 830 opening (e.g. Alves et al., 2009; Nirrengarten et al., 2017; Angrand et al., 2020). The 831 beginning of rifting is slightly diachronous among these basins as evidenced by the timing of 832 formation of their BSU (Fig. 12). Nearly all of the rifting sequences in the Tartas and Arzacq 833 (Désaglaux \& Brunet, 1990; Brunet, 1991; Serrano et al., 2006; Issautier et al., 2020), Parentis 834 (Brunet, 1994; Ferrer et al., 2008; Jammes et al., 2009; Tugend et al., 2015) and Columbrets 835 (Salas et al., 2001; Nebot \& Guimerà, 2016; Etheve, 2016; Etheve et al., 2018; Roma et al., 
837 Pyrenean Zone basins end their syn-rift sequence slightly earlier, as they are characterised by 838 a breakup sequence developing between the latest Albian and the Early Cenomanian (Fig. 12; 839 Masini et al., 2014; Teixell et al., 2016; Pedrera et al., 2017; Espurt et al., 2019; Labaume and 840 Teixell, 2020). Thus, the North Pyrenean Zone basins are characterised by the development of 841 a LBS surface (sensu Soares et al., 2012) separating the Early Cretaceous syn-rift sequence 842 and the Latest Albian to Early Cenomanian breakup sequence. Hence the syn-rift sequence of 843 the reviewed basins lasts around 35-45 Myr according to the timing of formation of the 844 different basins whereas the breakup sequence of the North Pyrenean Zone basins lasts about $8455 \mathrm{Myr}$ (Fig. 12). In contrast to the reviewed basins, the West Iberia margins have a relatively 846 short ( $20 \mathrm{Myr})$ syn-rift sequence and a longer ( 15 Myr) breakup sequence (Soares et al., 847 2012; Pereira \& Alves, 2012; Alves \& Cunha, 2018; Alves et al., 2020), and the Bay of 848 Biscay margins have equally long syn-rift and breakup sequences ( 20 Myr) (Fig. 12; 849 Montardet et al., 1979; Brunet, 1994; Thinon, 1999; Thinon et al., 2001, 2003; Tugend et al., 850 2015). This is consistent with interpretations of the West Iberia margin as having a syn-rift 851 sequence getting longer to the north and a continental breakup sequence becoming shorter to 852 the north (Alves et al., 2002, 2006, 2009).

853 All the reviewed basins record a post-rift thermal cooling stage in which a post-rift sequence 854 overlaps the syn-rift sequence in the Tartas, Arzacq, Cameros, Parentis and Columbrets basins 855 and the breakup sequence in the North-Pyrenean Zone basins, where they record a more 856 advanced Mesozoic extension. The post-rift unconformity is clearly visible in the reviewed 857 basins as erosional truncation of the syn-rift/breakup sequences and onlap of the post-rift 858 sequence, as seen in a seismic profile in the Arzacq (Fig. 2; Issautier et al., 2020), Parentis 859 (Fig. 4D; Jammes, 2019), and Columbrets (Figs. 5C-E; Etheve et al., 2018) basins, and in 860 field observations in the Cameros (Omodeo-Salé et al., 2014, 2017), Mauléon (e.g. Saspiturry 
et al., 2019a), Basque-Cantabrian (Rat, 1988) and Internal Metamorphic Zone (Debroas,

$8621978,1987,1990)$ basins. Although the North Pyrenean Zone basins underwent continental 863 breakup, it did not progress to oceanic spreading. It is conceivable that the Pyrenean 864 compression may have obliterated the stratigraphic evidence for a drifting stage in the North 865 Pyrenean Zone basins. However, (1) the entire mid-Cenomanian to Late Santonian post-rift 866 sequence is fully preserved above the North Pyrenean Zone hyperextended domain and 867 clearly records a post-rift thermal cooling stage, (2) there is no evidence of subducted oceanic 868 crust in a passive seismic Vp/Vs model of the Mauléon basin (Fig. 7B, Wang et al., 2016) and Internal Metamorphic Zone basins (Fig. 9B, Chevrot et al., 2018) or in a crustal-scale 3D

870 gravity inversion of the Basque-Cantabrian basin (Pedrera et al., 2017). In contrast to the

871 North Pyrenean Zone basins, oceanic spreading occurred during mid-Cenomanian time in the 872 eastern Bay of Biscay margins (Fig. 12; Montadert et al., 1979; Brunet 1994; Thinon, 1999; 873 Thinon et al., 2001, 2003; Gong et al., 2008; Tugend et al., 2015) and at the Cenomanian874 Turonian boundary in the Northwest Iberia margin and western Bay of Biscay margins (Fig. 12; Gong et al., 2008; Soares et al., 2012; Pereira \& Alves, 2012; Alves \& Cunha, 2018; 876 Alves et al., 2020). Although the duration of the breakup sequence differs strongly between 877 the North Pyrenean Zone basins and the Bay of Biscay and West Iberia margins, the breakup 878 affected all of these regions simultaneously from the mid-Cenomanian to the earliest Turonian 879 (Fig. 12).

\subsection{Architectural contrasts and discrepancies in the modes of crustal thinning}

881 Atlantic-type margins such as West Iberia (Boillot et al., 1980, 1995; Reston et al., 1995; 882 Whitmarsh et al., 2001; Péron-Pinvidic \& Manatschal, 2009; Sutra et al. 2013; Péron-Pinvidic 883 et al., 2015) or the Bay of Biscay margins (Jammes, 2009; Jammes et al., 2010a, 2010b, 884 2010c; Tugend et al., 2014) are characterized by five distinctive features: (1) deformation 885 coupling that occurs when the ductile layer has been removed and deformation in the strong 
and brittle upper crust couples with deformation in the strong lower crust/upper mantle, (2)

887 detachment faults at the top of the basement that accommodate crustal extension through tilting of blocks of the basement and their pre-rift cover showing a coupled deformation, (3) formation of continental crust extensional allochthons, made up of upper crust and pre-rift cover, tectonically placed over exhumed lower crust or serpentinized mantle, (4) a wide

891 domain of exposed subcontinental mantle at the ocean-continent transition and (5) large-scale

892 serpentinization of the exhumed mantle that was still active at ambient seawater temperatures (Fig. 13A). Numerical models of such systems reproduce the palaeoarchitecture of the continental margins and the detachment faults responsible for crustal thinning (Lavier \& Manatschal, 2006; Huismans \& Beaumont, 2011). Numerical studies have also shown that continental crust thinning develops under conditions of high heat flow from the mantle due to

897 asthenospheric upwelling. In these sediment-starved Atlantic-type margins, only small 898 volumes of syn-rift sedimentary cover can be found in the hyperextended domain (Masini et al., 2011, 2012; Péron-Pinvidic et al., 2015; Ribes et al., 2019) (Fig. 13A).

Palaeogeographic reconstructions (Ziegler, 1982; Dercourt et al., 1986; Ortí et al., 2017; Soto et al., 2017) show that the distribution of the Pyrenean and peri-Pyrenean smooth-slope extensional basins corresponds closely to the distribution of Late Triassic evaporites and claystones (Lagabrielle et al., 2020). Numerical modelling shows that these Triassic deposits

904 played a major role at the onset of continental rifting as zones of decoupling between the 905 Palaeozoic basement and the Jurassic to Albian sedimentary cover (Duretz et al., 2019). Thus 906 Triassic salt does not allow the coupling of the basement and its sedimentary cover during 907 crustal extension characteristic of Atlantic-type margins. Moreover, in smooth-slope basins, 908 the lower/middle crust is not exhumed during the breakup sequence, unlike Atlantic-type 909 margins, as it has been laterally extracted during initial rifting. In fact, the only lower crustal 910 rocks cropping out along the Cretaceous North Pyrenean Rift axis are quite old, having been 
911 previously exhumed during Permian time (de Saint-Blanquat, 1993; Olivier et al., 2004;

912 Cochelin et al., 2018a, 2018b; Saspiturry et al., 2019b).

913 Finally, unlike Atlantic-type margins, the hyperextended domain of smooth-slope basins

914 deforms under ductile conditions and HT/LP conditions due to (1) the displaced cover

915 remaining preserved in the centre of the basin while the lower crust is thinned ductilely and

916 (2) the continental crust being buried under a very thick pre-rift to syn-rift sedimentary cover.

917 However, as in Atlantic-type margins, the proximal margins become subject to extensional

918 brittle faulting as the crust acquires a normal thermal gradient of $\sim 30^{\circ} \mathrm{C} / \mathrm{km}$ (Saspiturry, 2019)

919 and the proximal sedimentary cover is thinned or removed (Fig. 13B). Thus in smooth-slope

920 basin margins, the proximal margins undergo brittle deformation while the hyperextended

921 domain undergoes ductile thinning due to a complex interaction between salt beds,

922 sedimentary burial and changes in the syn-rift thermal gradient (Fig. 13B). This elevated

923 thermal regime is associated with intense metasomatism and fluid circulation affecting both

924 the continental basement and the sedimentary cover at temperatures of $500-600^{\circ} \mathrm{C}(\mathrm{Corre}$ et

925 al., 2016; Quesnel et al., 2019; Lagabrielle et al., 2019a, 2019b). The peak syn-rift

926 temperature is mainly controlled by burial but can be locally influenced by fluid circulation.

927 Indeed, adiabatic temperatures in the sedimentary cover have been interpreted as the presence 928 of local fluid generation and convective cells in the Mauléon (Saspiturry, 2019) and 929 Boucheville (Boulvais et al., 2016) basins.

930 An important difference between the two geological settings is the fact that Atlantic-type 931 margin are sediment-starved (less than $2 \mathrm{~km}$ of burial) while smooth-slope basins are 932 sediment-rich (syn-rift sequence is more than $5 \mathrm{~km}$ thick). In addition, in the reviewed basins, 933 the pre-rift cover remaining in the central part of the basin, thanks to the Late Triassic salt 934 décollement, contributes significantly to the increase in burial and thus the peak temperature 935 at the base of the hyperextended domain by adding around $2-3 \mathrm{~km}$ of pre-rift sediments to 
936 preexisting syn-rift and breakup sedimentary sequences that are nearly $5 \mathrm{~km}$ thick. Therefore,

937 the thinned continental basement and the exhumed mantle may be buried under 7-10 $\mathrm{km}$ of 938 pre-rift to syn-breakup sediments. This allows the crust to deform in a ductile way. Finally, 939 the pre-rift salt, which is mostly absent along Atlantic-type margins, is also a major 940 contributor to sedimentary burial. Thus, it participates in the ductile thinning of the 941 continental crust and its sedimentary cover, as pointed out by Lagabrielle et al. (2020).

942 The review of the sequence of the main tectono-stratigraphic events presented in section 4.1

943 (Fig. 12) also sheds light on another possible controlling factor. Indeed, the duration of syn944 rift sequences in smooth-slope basins ( $35-45 \mathrm{Myr})$ is significantly longer than those of the 945 West Iberia and Bay of Biscay margins ( 15-20 Myr). Thus, the long lifetime of smooth946 slope extensional basins could favour the depth-dependent ductile thinning of the 947 lower/middle crust by pure shear at the beginning of the rifting stage and may prevent brittle 948 structures from forming within the upper crust.

\section{Conclusions}

950 We infer the evolution of smooth-slope type basins in the Iberian-Eurasian plate junction from 951 the rifting to the breakup stage. At the beginning of the syn-rift stage, depth-dependent crustal 952 thinning is dominantly controlled by distributed pure shear thinning within the lower/middle 953 crust due to the presence of two decoupling levels: (1) the middle crust, which allows the 954 lower crust to be extracted laterally without disturbing significantly the upper crust, and (2) 955 within pre-rift Triassic salt beds, which act as a décollement between the upper crust and the 956 overlying sedimentary cover. Then simple shear becomes localized along a crustal 957 detachment connecting upward with the Late Triassic décollement layer, inducing shearing in 958 the pre-rift salt. When continental breakup occurs, the basin flanks are affected by brittle 
960

961

962

963

964

965

966

967

968

969

970

971

972

973

974

975

976

977

978

979

980

981

982

983

984

985

986

987

of the $300^{\circ} \mathrm{C}$ to $500^{\circ} \mathrm{C}$ isotherms in the hyperextended domain, from the syn-rift to the continental breakup stage, implies that the originally crystalline upper continental crust and the overlying pre-rift and syn-rift sedimentary pile are affected by depth-dependent ductile thinning. The deformation style during rifting and continental breakup is mainly controlled by burial that results from the complex interaction between the syn-rift sedimentary sequence and the pre-rift salt beds that indirectly contribute to the burial by preserving from disruption the pre-rift sequence in the basin core.

To summarize, hyperextension in Atlantic-type margins leads to a progressive embrittlement of the continental crust due to progressive extraction of the ductile middle crust (e.g. PérezGussinyé et al., 2001; Reston, 2009; Sutra et al., 2013; Mohn et al., 2015). In margins with smooth-slope basins, in contrast, crustal thinning is mostly ductile. The latter is favoured by the lateral extraction of the deep crust and the occurrence of thick sedimentary cover (Asti et al., 2019; Duretz et al., 2019; Lagabrielle et al., 2020). This implies that in the distal domain of smooth-slope margins deformation coupling never occurs, thanks to progressive upward migration of the brittle/ductile transition during rifting. Finally, in the reviewed basins, sedimentary burial coupled to the presence of pre-rift salt and a long-lived rifting sequence allow the continental crust to stretch in a dominantly ductile regime from rifting until breakup.

\section{References}

Albarède, F., \& Michard-Vitrac, A., 1978a. Datation du metamorphisme des terrains secondaires des Pyrenees par les methodes 39 Ar-40 Ar et 87 Rb-87 Sr; ses relations avec les peridotites associees. Bull. Société Géologique Fr. 7, 681-687.

Albarède, Francis, \& Michard-Vitrac, A., 1978b. Age and Significance of the North Pyrenean Metamorphism. Earth Planet. Sci. Lett. 327-332.

Alhamawi, M., 1992. Sédimentologie, pétrographie sédimentaire et diagenèse des calcaires Crétacé supérieur de la marge ibérique, Vallées d'Ossau - Vallée d'Aspe, Haute Chaîne, Pyrénées Atlantiques. Université Bordeaux 1.

Alonso, A., \& Mas, J.R., 1993. Control tectónico e influencia del eustatismo en la sedimentación del Cretácico inferior de la cuenca de Los Cameros. 
Alvaro, M., del Villar, R.C., \& Vegas, R., 1979. Un modelo de evolución geotectónica para la Cadena Celtibérica. Acta Geológica Hispánica 14, 172-177.

Alves, T. M., R. L. Gawthorpe, D. H. Hunt, and J. H. Monteiro., 2002, Jurassic tectonosedimentary evolution of the Northern Lusitanian Basin (offshore Portugal), Mar. Pet. Geol., 19, 727-754, doi:10.1016/S0264-8172(02)00036-3.

Alves, T. M., C. Moita, F. Sandnes, T. Cunha, J. H. Monteiro, and L. M. Pinheiro (2006), Mesozoic - Cenozoic evolution of North Atlantic continental slope basins: The Peniche basin, western Iberian margin, AAPG Bull., 90, 31 - 60, doi:10.1306/08110504138.

Alves, T.M., Moita, C., Cunha, T., Ullnaess, M., Myklebust, R., Monteiro, J.H., Manupella, G., 2009. Diachronous evolution of Late Jurassic-Cretaceous continental rifting in the northeast Atlantic (west Iberian margin). Tectonics 28. https://doi.org/10.1029/2008TC002337.

Alves, T.M., Cunha, T.A., 2018. A phase of transient subsidence, sediment bypass and deposition of regressive-transgressive cycles during the breakup of Iberia and Newfoundland. Earth Planet Sci. Lett. 484, 168-183. https://doi.org/10.1016/j.epsl.2017.11.054.

Alves, T.M., Fetter, M., Busby, C., Gontijo, R., Cunha, T., Mattos, N.H., 2020, A tectonostratigraphic review of continental breakup on intraplate continental margins and its impact on resultant hydrocarbon systems. Marine and Petroleum Geology, 117. https://doi.org/10.1016/j.marpetgeo.2020.104341

Angrand, P., Ford, M., \& Watts, A.B., 2018. Lateral Variations in Foreland Flexure of a Rifted Continental Margin: The Aquitaine Basin (SW France): Flexure of the Aquitaine Foreland Basin. Tectonics 37, 430-449. https://doi.org/10.1002/2017TC004670

Angrand, P., Mouthereau, F., Masini, E., Asti, R., 2020. A reconstruction of Iberia accounting for W-Tethys/N-Atlantic kinematics since the late Permian-Triassic, Solid Earth. 10.5194/se-2020-24.

Arche, A., \& López-Gómez, J., 1996. Origin of the Permian-Triassic Iberian Basin, centraleastern Spain. Tectonophysics 266, 443-464. https://doi.org/10.1016/S00401951(96)00202-8

Arnaud-Vanneau, A., Arnaud, H., Charollais, J., Conrad, M.-A., Cotillon, P., Ferry, S., Masse, J.-P., \& Peybernès, B., 1979. Paléogéographie des calcaires urgoniens du sud de la France. Géobios 3, 363-383.

Asti, R., Lagabrielle, Y., Fourcade, S., Corre, B., \& Monié, P., 2019. How Do Continents Deform During Mantle Exhumation? Insights From the Northern Iberia Inverted Paleopassive Margin, Western Pyrenees (France). Tectonics 2018TC005428. https://doi.org/10.1029/2018TC005428

Aurell, M., \& Meléndez, A., 1993. Sedimentary evolution and sequence stratigraphy of the Upper Jurassic in the central Iberian Chain, northeast Spain. Spec. Publ. Int. Ass. Sediment.

Aurell, M., Robles, S., Bádenas, B., Rosales, I., Quesada, S., Meléndez, G., \& García-Ramos, J.., 2003. Transgressive-regressive cycles and Jurassic palaeogeography of northeast Iberia. Sediment. Geol. 162, 239-271. https://doi.org/10.1016/S0037-0738(03)001544

Ayala, C., Pous, J., \& Torné, M., 1996. The lithosphere-asthenosphere boundary of the Valencia Trough (western Mediterranean) deduced from 2D Geoid and Gravity Modelling. Geophys. Res. Lett. 23, 3131-3134. https://doi.org/10.1029/96GL03005

Ayala, C., Torne, M., \& Pous, J., 2003. The lithosphere-asthenosphere boundary in the western Mediterranean from 3D joint gravity and geoid modeling: tectonic 
implications. Earth Planet. Sci. Lett. 209, 275-290. https://doi.org/10.1016/S0012821X(03)00093-1

Ayala, C., Torne, M., \& Roca, R., 2015. A review of the current knowledge of the crustal and lithospheric structure of the Valencia Trough Basin. Bol. Geológico Min. 126, 533552.

Azambre, B., \& Rossy, M., 1976. Le magmatisme alcalin d'age cretace, dans les Pyrenees occidentales et l'Arc basque; ses relations avec le metamorphisme et la tectonique. Bull. Société Géologique Fr. 7, 1725-1728.

Banda, E., \& Santanach, P., 1992. The Valencia trough (western Mediterranean): An overview. Tectonophysics 208, 183-202. https://doi.org/10.1016/00401951(92)90344-6

Barbier, F., Duvergé, J., \& Le Pichon, X., 1986. Structure profonde de la marge Nord Gascogne. Implications sur le mécanisme de rifting et de formation de la marge continentale. Bull Cent Rech Explor Prod Elf Aquitaine 10, 105-121.

Bernus-Maury, C., 1984. Etude des paragéneses caractéristiques du métamorphisme mésozoïque dans la partie orientale des Pyrénées. Pierre et Marie Curie, Paris.

Biteau, J., \& Canérot, J., 2007. La Chaine des Pyrenees et ses avant-pays d'Aquitaine et de l'Ebre: caracteristiques structurales, evolution geodynamique et tectono-sedimentaire. Geol.-PARIS- 155, 16.

Biteau, J.-J., Le Marrec, A., Le Vot, M., \& Masset, J.-M., 2006. The Aquitaine Basin. Pet. Geosci. 12, 247-273.

Bixel, F., 1984. Le volcanisme stéphano-permien des Pyrénées. Université Paul Sabatier de Toulouse (Sciences).

Bixel, F., \& Lucas, C.L., 1983. Magmatisme, tectonique et sédimentation dans les fossés stéphano-permiens des Pyrénées occidentales. Rev. Géologie Dyn. Géographie Phys. 24, 329-342.

Bixel, F., \& Lucas, C., 1987. Approche Géodynamique du Permien et du Trias des Pyrénées dans le cadre du sud-ouest européen. Cuad. Geol. Ibérica 11, 57-81.

Boillot, G., Beslier, M.O., Krawczyk, C.M., Rappin, D., \& Reston, T.J., 1995. The formation of passive margins: constraints from the crustal structure and segmentation of the deep Galicia margin, Spain. Geol. Soc. Lond. Spec. Publ. 90, 71-91.

Boillot, G., Capdevilla, R., Hennequin-Marchand, I., Lamboy, M., \& Lepretre, J.P., 1973. La zone nord-pyrénéenne, ses prolongements sur la marge continentale nord-espagnole et sa signification structurale. Comptes Rendus Acad. Sci. Paris 227, 2629-2632.

Boillot, G., Féraud, G., Recq, M., \& Girardeau, J., 1989. Undercrusting by serpentinite beneath rifted margins: the example of the west Galicia margin (Spain). Nature 341, 523-525.

Boillot, G., Grimaud, S., Mauffret, A., Mougenot, D., Kornprobst, J., Mergoil-Daniel, J., \& Torrent, G., 1980. Ocean-continent boundary of the Iberian margin: a serpentinite diapir west of the Galicia Bank. Earth Planet. Sci. Lett. 48, 23-34.

Boillot, G., Recq, M., Winterer, E.L., Meyer, A.W., Applegate, J., Baltuck, M., . . Dunham, K., \& others, 1987. Tectonic denudation of the upper mantle along passive margins: a model based on drilling results (ODP leg 103, western Galicia margin, Spain). Tectonophysics 132, 335-342.

Boirie, J.-M., 1981. Etude Sédimentologique des Poudingues de Mendibelza (Pyrénées Atlantiques). Université Paul Sabatier de Toulouse (Sciences), Toulouse.

Boirie, J.-M., \& Souquet, P., 1982. Les poudingues de Mendibelza: dépôts de cônes sousmarins du rift albien des Pyrénées. Bull. Cent. Rech. Explor.-Prod. Elf-Aquitaine 6, 405-435. 
1087

1088

1089

1090

1091

1092

1093

1094

1095

1096

1097

1098

1099

1100

1101

1102

1103

1104

1105

1106

1107

1108

1109

1110

1111

1112

1113

1114

1115

1116

1117

1118

1119

1120

1121

1122

1123

1124

1125

1126

1127

1128

1129

1130

1131

1132

1133

1134

1135

Bois, C., 1992. The evolution of the layered lower crust and the Moho through geological time in Western Europe: contribution of deep seismic reflection profiles. Terra Nova 4, 99-108.

Bois, C., \& Courtillot, V., 1988. Deep Seismic Profiling of the Crust and Evolution of the Lithosphere 69, 987-988.

Bois, C., \& ECORS Scientific team, 1990. Major geodynamic processes studied from the ECORS deep seismic profiles in France and adjacent areas. Tectonophysics 173, 397410.

Bois, C., Gabriel, O., Lefort, J.-P., Rolet, J., Brunet, M.-F., Masse, P., \& Olivet, J.-L., 1997. Geologic contribution of the Bay of Biscay deep seismic survey: a summary of the main scientific results, a discussion of the open questions and suggestions for further investigation. Mém Soc Géol Fr. 193-309.

Bois, C., \& Gariel, O., 1994. Deep Seismic Investigation in the Parentis Basin (Southwestern France), in: Mascle, A. (Ed.), Hydrocarbon and Petroleum Geology of France. Springer Berlin Heidelberg, Berlin, Heidelberg, pp. 173-186. https://doi.org/10.1007/978-3-642-78849-9_13

Boulvais, P., 2016. Fluid generation in the Boucheville Basin as a consequence of the North Pyrenean metamorphism. Comptes Rendus Geosci. 348, 301-311. https://doi.org/10.1016/j.crte.2015.06.013

Bouroullec, J., Delfaud, J., \& Deloffre, R., 1979. Organisations sédimentaire et paléocologique de l'Aptien supérieur a faciès urgonien dans les Pyrénées occidentales et l'Aquitaine méridionale. Geobios 12, 25-43.

Bouroullec, J., \& Deloffre, R., 1970. Interprétation sédimentologique et paléogéographique par microfaciès du Crétacé inférieur basal d'Aquitaine Sud-Ouest. Bull. Cent. Rech. Pau-SNPA 4, 381-429.

Bourrouilh, R., Richert, J.-P., \& Zolnaï, G., 1995. The North Pyrenean Aquitaine Basin, France: Evolution and Hydrocarbons. AAPG Bull. 79, 831-853.

BRGM, Elf, Esso, \& SNPA, 1974. Géologie du Bassin d'aquitaine. BRGM Editions, Paris.

Brune, S., Heine, C., Pérez-Gussinyé, M., \& Sobolev, S.V., 2014. Rift migration explains continental margin asymmetry and crustal hyper-extension. Nat. Commun. 5. https://doi.org/10.1038/ncomms5014

Brune, S., Williams, S.E., Butterworth, N.P., \& Müller, R.D., 2016. Abrupt plate accelerations shape rifted continental margins. Nature 536, 201-204. https://doi.org/10.1038/nature18319

Brunet, M.-F., 1991. Subsidence et géodynamique du Bassin d'Aquitaine. Relations avec l'ouverture de l'Atlantique.

Brunet, M. F., 1994, Subsidence in the Parentis Basin (Aquitaine, France): Implications of the Thermal Evolution, ed, in Mascle, A., Hydrocarbon and Petroleum Geology of France: Special Publication of the European Association of Petroleum Geoscientists, Volume 4, p.187-198.

Burg, J.-P., Van Den Driessche, J., \& Brun, J.-P., 1994. Syn- to post-thickening extension : mode and consequences. Comptes Rendus Académie Sci. Sér. 2 Sci. Terre Planètes $319,1019-1032$.

Cámara, P., 2020. Inverted turtle salt anticlines in the Eastern Basque-Cantabrian basin, $\begin{array}{llll}\text { Spain. Marine } & 117 .\end{array}$ https://doi.org/10.1016/j.marpetgeo.2020.104358

Canérot, J., 1988. Manifestations de l'halocinèse dans les chaînons béarnais (zone NordPyrénéenne) au Crétacé inférieur. Comptes Rendus Académie Sci. Sér. 2 Mécanique Phys. Chim. Sci. Univers Sci. Terre 306, 1099-1102. 
Canérot, J., 1989. Rifting éocrétacé et halocinèse sur la marge ibérique des Pyrénées Occidentales (France). Conséquences structurales. Bull. Cent. Rech. Explor.-Prod. ElfAquitaine 13, 87-99.

Canérot, J., 2008. Les Pyrénées: Histoire géologique. Atlantica.

Canérot, J., Hudec, M.R., \& Rockenbauch, K., 2005. Mesozoic diapirism in the Pyrenean orogen: Salt tectonics on a transform plate boundary. AAPG Bull. 89, 211-229. https://doi.org/10.1306/09170404007

Canérot, J., \& Lenoble, J.-L., 1993. Diapirisme crétacé sur la marge ibérique des Pyrénées occidentales; exemple du pic de Lauriolle; comparaisons avec l'Aquitaine, les Pyrénées centrales et orientales. Bull. Société Géologique Fr. 164, 719-726.

Canérot, J., Majesté-Menjoulas, C., \& Ternet, Y., 1999. Le cadre stratigraphique et géodynamique des altérites et des bauxites sur la marge ibérique des Pyrénées occidentales (France). Comptes Rendus Académie Sci.-Ser. IIA-Earth Planet. Sci. 328, 451-456.

Carballo, A., Fernandez, M., Torne, M., Jiménez-Munt, I., \& Villaseñor, A., 2015. Thermal and petrophysical characterization of the lithospheric mantle along the northeastern Iberia geo-transect. Gondwana Res. 27, 1430-1445. https://doi.org/10.1016/j.gr.2013.12.012

Casas, A., Kearey, P., Rivero, L., \& Adam, C.R., 1997. Gravity anomaly map of the Pyrenean region and a comparison of the deep geological structure of the western and eastern Pyrenees. Earth Planet. Sci. Lett. 150, 65-78.

Casas, A.M., Cortés, A.L., \& Maestro, A., 2000. Intra-plate deformation and basin formation during the Tertiary at the Northern Iberian Plate: origin and evolution of the Almazán Basin. Tectonics 19, 258-289.

Casas, A.M., Villalaín, J.J., Soto, R., Gil-Imaz, A., del Río, P., \& Fernández, G., 2009. Multidisciplinary approach to an extensional syncline model for the Mesozoic Cameros Basin (N Spain). Tectonophysics 470, 3-20. https://doi.org/10.1016/j.tecto.2008.04.020

Casas Sainz, A.M., 1993. Oblique tectonic inversion and basement thrusting in the Cameros Massif (Northern Spain). Geodin. Acta 6, 202-216. https://doi.org/10.1080/09853111.1993.11105248

Casas-Sainz, A.M., \& Gil-Imaz, A., 1998. Extensional subsidence, contractional folding and thrust inversion of the eastern Cameros basin, northern Spain. Geol. Rundsch. 86, 802-818. https://doi.org/10.1007/s005310050178

Casas-Sainz, A.M., \& Simón-Gómez, J., 1992. Stress field and thrust kinematics: a model for the tectonic inversion of the cameros massif (Spain). J. Struct. Geol. 14, 521-530. https://doi.org/10.1016/0191-8141(92)90154-O

Casquet, C., Galindo, C., González-Casado, J.M., Alonso, A., Mas, R., Rodas, M., García, E., \& Barrenechea, J.F., 1992. El metamorfismo en la cuenca de los Cameros; geocronologia e implicaciones tectonicas. Geogaceta 11, 22-25.

Castañares, L.M., \& Robles, S., 2004. El vulcanismo del Albiense-Santoniense en la Cuenca Vasco-Cantábrica. Geol. Esp.

Castañares, L.M., Robles, S., \& Vicente Bravo, J.C., 1997. Distribución estratigráfica de los episodios volcánicos submarinos del Albiense-Santoniense en la Cuenca Vasca (sector Gernika-Plentzia, Bizkaia).

Casteras, M., 1933. Recherches sur la structure du versant nord des Pyrénées centrales et orientales. Libraire Polytechnique, C. Béranger.

Casteras, M., 1971. Carte géologique de la France à 1/50 000: feuille de Tardets-Sorholus, Orléans, France. 
Chelalou, R., Nalpas, T., Bousquet, R., Prevost, M., Lahfid, A., Poujol, M., Ringenbach, J.C., \& Ballard, J.-F., 2016. New sedimentological, structural and paleo-thermicity data in the Boucheville Basin (eastern North Pyrenean Zone, France). Comptes Rendus Géoscience 348, 312-321.

Chevrot, S., Sylvander, M., Diaz, J., Martin, R., Mouthereau, F., Manatschal, G., . . . Ruiz, M., 2018. The non-cylindrical crustal architecture of the Pyrenees. Sci. Rep. 8, 9591. https://doi.org/10.1038/s41598-018-27889-x

Choukroune, P., 1974. Structure et évolution tectonique de la zone nord-pyrénéenne: analyse de la déformation dans une portion de chaîne à schistosité sub-verticale.

Choukroune, P., \& ECORS Team, 1989. The ECORS Pyrenean deep seismic profile reflection data and the overall structure of an orogenic belt. Tectonics 8, 23-39.

Choukroune, P., \& Mattauer, M., 1978. Tectonique des plaques et Pyrenees; sur le fonctionnement de la faille transformante nord-pyreneenne; comparaisons avec des modeles actuels. Bull. Société Géologique Fr. 7, 689-700.

Clerc, C., 2012. Evolution du domaine nord-pyrénéen au Crétacé: amincissement crustal extrême et thermicite élevée: un analogue pour les marges passives. Paris 6.

Clerc, C., Boulvais, P., Lagabrielle, Y., \& de Saint Blanquat, M., 2014. Ophicalcites from the northern Pyrenean belt: a field, petrographic and stable isotope study. Int. J. Earth Sci. 103, 141-163. https://doi.org/10.1007/s00531-013-0927-z

Clerc, C., Lahfid, A., Monié, P., Lagabrielle, Y., Chopin, C., . . de St Blanquat, M., 2015. High-temperature metamorphism during extreme thinning of the continental crust: a reappraisal of the North Pyrenean passive paleomargin. Solid Earth 6, 643-668.

Clerc, C., \& Lagabrielle, Y., 2014. Thermal control on the modes of crustal thinning leading to mantle exhumation: Insights from the Cretaceous Pyrenean hot paleomargins. Tectonics 33, 1340-1359. https://doi.org/10.1002/2013TC003471

Clerc, C., Lagabrielle, Y., Labaume, P., Ringenbach, J.-C., Vauchez, A., Nalpas, T., . . . Fourcade, S., 2016. Basement - Cover decoupling and progressive exhumation of metamorphic sediments at hot rifted margin. Insights from the Northeastern Pyrenean analog. Tectonophysics 686, 82-97. https://doi.org/10.1016/j.tecto.2016.07.022

Cobbold, P.R., \& Szatmari, P., 1991. Radial gravitational gliding on passive margins. Tectonophysics 188, 249-289.

Cochelin, B., 2016. Champ de déformation du socle paléozoïque des Pyrénées. Géosciences Environnement Toulouse (GET).

Cochelin, B., Chardon, D., Denèle, Y., Gumiaux, C., \& Le Bayon, B., 2017. Vertical strain partitioning in hot Variscan crust: Syn-convergence escape of the Pyrenees in the Iberian-Armorican syntax. Bull. Société Géologique Fr. 188, 39.

Cochelin, B., Lemirre, B., Denèle, Y., Blanquat, M. de S., Lahfid, A., Duchêne, S., 2018a, Structural inheritance in the central Pyrenees: the variscan to Alpine tectonometamorphic evolution of the axial zone. J. Geol. Soc., v. 175, 336-351, doi:10.1144/jgs2017-066.

Cochelin, B., Gumiaux, C., Chardon, D., Denèle, Y., Le Bayon, B., 2018b, Multi-scale strainfield analysis using geostatistics: Investigating the rheological behavior of the hot Variscan crust of the Pyrenees (Axial Zone). J. Struct. Geol., v. 116, 114-130, doi:10.1016/j.jsg.2018.07.024

Combes, P.-J., Peybernès, B., \& Leyreloup, A.F., 1998. Altérites et bauxites, témoins des marges européenne et ibérique des Pyrénées occidentales au Jurassique supérieurCrétacé inférieur, à l'ouest de la vallée d'Ossau (Pyrénées-Atlantiques, France). Comptes Rendus Académie Sci.-Ser. IIA-Earth Planet. Sci. 327, 271-278. 
Corre, B., 2017. La bordure nord de la plaque ibérique à l'Albo-Cénomanien: architecture d'une marge passive de type ductile (Chaînons Béarnais, Pyrénées Occidentales) (PhD Thesis). Rennes 1.

Corre, B., Lagabrielle, Y., Labaume, P., Fourcade, S., Clerc, C., \& Ballèvre, M., 2016. Deformation associated with mantle exhumation in a distal, hot passive margin environment: New constraints from the Saraillé Massif (Chaînons Béarnais, NorthPyrenean Zone). Comptes Rendus Geosci. 348, 279-289. https://doi.org/10.1016/j.crte.2015.11.007

Cuevas, J., \& Tubia, J.M., 1999. The discovery of scapolite marbles in the Biscay Synclinorium (Basque-Cantabrian basin, Western Pyrenees): geodynamic implications. Terra Nova 11, 259-265. https://doi.org/10.1046/j.13653121.1999.00255.x

Curnelle, R., 1983. Evolution structuro-sédimentaire du Trias et de 1'Infra-Lias d'Aquitaine. Bull Cent Rech Explor Prod Elf-Aquitaine 7, 69-99.

Curnelle, R., \& Dubois, P., 1986. Evolution mesozoique des grands bassins sedimentaires francais; bassins de Paris, d'Aquitaine et du Sud-Est. Bull. Soc. Geol. Fr. II, 529-546. https://doi.org/10.2113/gssgfbull.II.4.529

Curnelle, R., Dubois, P., Seguin, J.C., Whitaker, D., Matthews, D.H., Roberts, D.G., . . . Kholief, M.M., 1982. The Mesozoic-Tertiary Evolution of the Aquitaine Basin [and Discussion]. Philos. Trans. R. Soc. Math. Phys. Eng. Sci. 305, 63-84. https://doi.org/10.1098/rsta.1982.0026

Daignières, M., Séguret, M., Specht, M., \& Team, E., 1994. The Arzacq-western Pyrenees ECORS deep seismic profile, in: Hydrocarbon and Petroleum Geology of France. Springer, pp. 199-208.

Dañobeitia, J.J., Arguedas, M., Gallart, J., Banda, E., \& Makris, J., 1992. Deep crustal configuration of the Valencia trough and its Iberian and Balearic borders from extensive refraction and wide-angle reflection seismic profiling. Tectonophysics 203, $37-55$.

Dardel, R.A., \& Rosset, R., 1971. Histoire géologique et structurale du bassin de Parentis et de son prolongement en mer. Hist. Struct. Golfe Gasc. 2.

Dauteuil, O., \& Ricou, L.-E., 1989. Une circulation de fluides de haute-température à l'origine du métamorphisme crétacé nord-pyrénéen. Geodin. Acta 3, 237-249. https://doi.org/10.1080/09853111.1989.11105190

de Saint Blanquat, M., 1993. La faille normale ductile du massif du Saint Barthélémy. Evolution hercynienne des massifs nord-pyrénéens catazonaux considérée du point de vue de leur histoire thermique. Geodin. Acta 6, 59-77.

de Saint Blanquat, M., Bajolet, F., Grand'Homme, A., Proietti, A., Zanti, M., Boutin, A., . . . Labaume, P., 2016. Cretaceous mantle exhumation in the central Pyrenees: New constraints from the peridotites in eastern Ariège (North Pyrenean zone, France). Comptes Rendus Geosci. 348, 268-278. https://doi.org/10.1016/j.crte.2015.12.003

Debroas, E.J., 1978. Evolution de la fosse du flysch ardoisier de l'Albien superieur au Senonien inferieur (zone interne metamorphique des Pyrenees navarrolanguedociennes). Bull. Société Géologique Fr. 7, 639-648.

Debroas, E.-J., 1987. Modèle de bassin triangulaire à l'intersection de décrochements divergents pour le fossé albo-cénomanien de la Ballongue (zone nord-pyrénéenne, France). Bull. Société Géologique Fr. 3, 887-898. https://doi.org/10.2113/gssgfbull.III.5.887

Debroas, E.J., 1990. Le flysch noir albo-cenomanien temoin de la structuration albienne a senonienne de la Zone nord-pyreneenne en Bigorre (Hautes-Pyrenees, France). Bull. Soc. Geol. Fr. VI, 273-285. https://doi.org/10.2113/gssgfbull.VI.2.273 
1283

1284

1285

1286

1287

1288

1289

1290

1291

1292

1293

1294

1295

1296

1297

1298

1299

1300

1301

1302

1303

1304

1305

1306

1307

1308

1309

1310

1311

1312

1313

1314

1315

1316

1317

1318

1319

1320

1321

1322

1323

1324

1325

1326

1327

1328

1329

1330

1331

Debroas, E.J., Canérot, J., \& Bilotte, M., 2010. Les brèches d'Urdach, témoins de l'exhumation du manteau pyrénéen dans un escarpement de faille vraconniencénomanien inférieur (Zone nord-pyrénéenne, Pyrénées-Atlantiques, France). Géologie Fr. 2, 53-63.

DeFelipe, I., Pedreira, D., Pulgar, J.A., Iriarte, E., \& Mendia, M., 2017. Mantle exhumation and metamorphism in the Basque-Cantabrian Basin (NSpain): Stable and clumped isotope analysis in carbonates and comparison with ophicalcites in the North-Pyrenean Zone (Urdach and Lherz). Geochem. Geophys. Geosystems 18, 631-652. https://doi.org/10.1002/2016GC006690

Del Río, P., Barbero, L., Mata, P., \& Fanning, C.M., 2009. Timing of diagenesis and very low-grade metamorphism in the eastern sector of the Sierra de Cameros (Iberian Range, Spain): a U-Pb SHRIMP study on monazite: U-Pb dating of diagenetic and low-grade monazite from the Iberian Range (Spain). Terra Nova 21, 438-445. https://doi.org/10.1111/j.1365-3121.2009.00900.x

Delfaud, J., 1969. Essai sur la géologie dynamique du domaine aquitano-pyrénéen durant le Jurassique et le Crétacé inférieur. Université de Bordeaux.

Delfaud, J., \& Gautier, J., 1967. Evolution des milieux de dépôts au passage JurassiqueCrétacé du forage de Lacq 104 (Aquitaine, France, Sud-Ouest). Bull. Cent. Rech. PauSNPA 1, 77-89.

Delfaud, J., \& Henry, J., 1967. Evolution des bassins jurassiques dans la zone nordpyrénéenne occidentale. 64ème Congrès AFAS Bordx. 75-80.

Delfaud, J., \& Villanova, M., 1967. Evolution des bassins pendant le Crétacé inférieur dans les Pyrénees occidentales et la bordure de l'Aquitaine. 64ème Congrès AFAS Bordx. 87-92.

Demercian, S., Szatmari, P., \& Cobbold, P.R., 1993. Style and pattern of salt diapirs due to thin-skinned gravitational gliding, Campos and Santos basins, offshore Brazil. Tectonophysics 228, 393-433.

Dercourt, J., Zonenshain, L.P., Ricou, L.-E., Kazmin, V.G., Le Pichon, X., Knipper, A.L., . . . Biju-Duval, B., 1986. Geological evolution of the tethys belt from the atlantic to the pamirs since the LIAS. Tectonophysics 123, 241-315. https://doi.org/10.1016/00401951(86)90199-X

Désaglaux, P., \& Brunet, M.-F., 1990. Tectonic subsidence of the Aquitaine basin since Cretaceous times. Bull. Société Géologique Fr. 8, 295-306.

Dielforder, A., Frasca, G., Brune, S \& Ford, M., 2019. Formation of the Iberian-European Convergent Plate Boundary Fault and Its Effect on Intraplate Deformation in Central Europe. Geochemistry Geophysics Geosystems. https://doi.org/10.1029/2018GC007840.

Driscoll, N.W., Hogg, J.R., Christie-Blick, N., \& Karner, G.D., 1995. Extensional tectonics in the Jeanne d'Arc Basin, offshore Newfoundland: implications for the timing of breakup between Grand Banks and Iberia. Geol. Soc. Lond. Spec. Publ. 90, 1-28. https://doi.org/10.1144/GSL.SP.1995.090.01.01

Ducoux, M., 2017. Structure, thermicité et évolution géodynamique de la Zone Interne Métamorphique des Pyrénées. Institut des Sciences de la Terre d'Orléans (ISTO).

Ducoux, M., Jolivet, L., Callot, J. -P., Aubourg, C., Masini, E., Lahfid, A., . . . Baudin, T., 2019. The Nappe des Marbres unit of the Basque-Cantabrian Basin: the tectono-thermal evolution of a fossil hyperextended rift basin. Tectonics 2018TC005348. https://doi.org/10.1029/2018TC005348

Duée, G., Lagabrielle, Y., Coutelle, A., \& Fortané, A., 1984. Les lherzolites associées aux Chaînons Béarnais (Pyrénées Occidentales): Mise à l'affleurement anté-dogger et 
resédimentation albo-cénomanienne. Comptes-Rendus Séances Académie Sci. Sér. 2 Mécanique-Phys. Chim. Sci. Univers Sci. Terre 299, 1205-1210.

Duretz, T., Asti, R., Lagabrielle, Y., Brun, J., Jourdon, A., Clerc, C., \& Corre, B., 2019. Numerical modelling of Cretaceous Pyrenean Rifting: The interaction between mantle exhumation and syn-rift salt tectonics. Basin Res. bre.12389. https://doi.org/10.1111/bre.12389

Espurt, N., Angrand, P., Teixell, A., Labaume, P., Ford, M., de Saint Blanquat, M., \& Chevrot, S., 2019. Crustal-scale balanced cross-section and restorations of the Central Pyrenean belt (Nestes-Cinca transect): Highlighting the structural control of Variscan belt and Permian-Mesozoic rift systems on mountain building. Tectonophysics 764, $25-45$.

Etheve, N., 2016. Le bassin de Valence à la frontière des domaines ibérique et méditerranéen: Evolution tectonique et sédimentaire du Mésozoïque au Cénozoïque. Université de Cergy Pontoise.

Etheve, N., Mohn, G., Frizon de Lamotte, D., Roca, E., Tugend, J., \& Gómez-Romeu, J., 2018. Extreme Mesozoic Crustal Thinning in the Eastern Iberia Margin: The Example of the Columbrets Basin (Valencia Trough). Tectonics 37, 636-662.

Fabriès, J., Lorand, J.-P., \& Bodinier, J.-L., 1998. Petrogenetic evolution of orogenic lherzolite massifs in the central and western Pyrenees. Tectonophysics 292, 145-167.

Fabriès, J., Lorand, J.-P., Bodinier, J.-L., \& Dupuy, C., 1991. Evolution of the Upper Mantle beneath the Pyrenees: Evidence from Orogenic Spinel Lherzolite Massifs. J. Petrol. Special_Volume, 55-76. https://doi.org/10.1093/petrology/Special_Volume.2.55

Fernandez, M., Foucher, J.P., \& Jurado, M.J., 1995. Evidence for the multi-stage formation of the south-western Valencia Trough. Mar. Pet. Geol. 12, 101-109. https://doi.org/10.1016/0264-8172(95)90390-6

Ferrer, O., Jackson, M.P.A., Roca, E., \& Rubinat, M., 2012. Evolution of salt structures during extension and inversion of the Offshore Parentis Basin (Eastern Bay of Biscay). Geol. Soc. Lond. Spec. Publ. 363, 361-380. https://doi.org/10.1144/SP363.16

Ferrer, O., Roca, E., Benjumea, B., Muñoz, J.A., Ellouz, N., \& MARCONI Team, 2008. The deep seismic reflection MARCONI-3 profile: Role of extensional Mesozoic structure during the Pyrenean contractional deformation at the eastern part of the Bay of Biscay. Mar. Pet. Geol. 25, 714-730. https://doi.org/10.1016/j.marpetgeo.2008.06.002

Ferrer, O., Roca, E., Jackson, M.P.A., \& Muñoz, J.A., 2009. Effects of Pyrenean contraction on salt structures of the offshore Parentis Basin (Bay of Biscay). Trab. Geol. 29.

Fixari, G., 1984. Stratigraphie, faciès et dynamique tecto-sédimentaire du flysch albien (flysch noir et poudingues de mendibelza) dans la région de Mauléon-Tardets (Pyrénées Atlantiques). Université Paul Sabatier de Toulouse (Sciences).

Fort, X., Brun, J.-P., \& Chauvel, F., 2004a. Salt tectonics on the Angolan margin, synsedimentary deformation processes. AAPG Bull. 88, 1523-1544.

Fort, X., Brun, J.P., \& Chauvel, F., 2004b. Contraction induced by block rotation above salt (Angolan margin). Mar. Pet. Geol. 21, 1281-1294.

Fortané, A., Duée, G., Lagabrielle, Y., \& Coutelle, A., 1986. Lherzolites and the western "Chaînons Béarnais" (French Pyrenees): Structural and paleogeographical pattern. Tectonophysics 129, 81-98. https://doi.org/10.1016/0040-1951(86)90247-7

Frizon de Lamotte, D., Raulin, C., Mouchot, N., Wrobel-Daveau, J.-C., Blanpied, C., \& Ringenbach, J.-C., 2011. The southernmost margin of the Tethys realm during the Mesozoic and Cenozoic: Initial geometry and timing of the inversion processes: TETHYS SOUTHERNMOST MARGIN. Tectonics 30, n/a-n/a. https://doi.org/10.1029/2010TC002691 
Froitzheim, N., \& Manatschal, G., 1996. Kinematics of Jurassic rifting, mantle exhumation, and passive-margin formation in the Austroalpine and Penninic nappes (eastern Switzerland). Geol. Soc. Am. Bull. 108, 1120-1133. https://doi.org/10.1130/00167606(1996)108<1120:KOJRME>2.3.CO;2

Gallart, J., Rojas, H., Diaz, J., \& Dañobeitia, J.J., 1990. Features of deep crustal structure and the onshore-offshore transition at the Iberian flank of the Valencia Trough (Western Mediterranean). J. Geodyn. 12, 233-252.

Gallart, J., Vidal, N., \& Danobeitia, J., 1994. Lateral variations in the deep crustal structure at the Iberian margin of the Valencia trough imaged from seismic reflection methods. Tectonophysics 232, 59-75. https://doi.org/10.1016/0040-1951(94)90076-0

García Mondéjar, J., Agirrezabala, L., M., Aranburu, A., Fernandez-Mendiola, P., A., GomèzPérèz, I., Lopez-Horgue, M., \& Rosales, I., 1996. Aptian-Albian tectonic pattern of the Basque - Cantabrian Basin (Northern Spain). Geol. J. 31, 13-45.

García-Lasanta, C., Casas-Sainz, A., Villalaín, J.J., Oliva-Urcia, B., Mochales, T., \& Speranza, F., 2017. Remagnetizations used to unravel large-scale fold kinematics: A case study in the Cameros Basin (Northern Spain): Unfolding in Basin Inversion. Tectonics 36, 714-729. https://doi.org/10.1002/2016TC004459

Garcia-Senz, J., Pedrera, A., Ayala, C., Ruiz-Constán, A., Robador Moreno, A., RodríguezFernández, R., 2019, Inversion of the North-Iberian hyperextended margin: the role of exhumed mantle indentation during continental collision. Geological Society, London, Special Publications, 490, doi: https://doi.org/10.1144/SP490-2019-112.

Gaullier, V., Brun, J.P., Gueīrin, G., \& Lecanu, H., 1993. Raft tectonics: the effects of residual topography below a salt deīcollement. Tectonophysics 228, 363-381.

Golberg, J.M., Guiraud, M., Maluski, H., \& Séguret, M., 1988. Caractères pétrologiques et âge du métamorphisme en contexte distensif du bassin sur décrochement de Soria (Crétacé inférieur, Nord Espagne). Comptes Rendus Académie Sci. Sér. 2 Mécanique Phys. Chim. Sci. Univers Sci. Terre 307, 521-527.

Golberg, J.M., \& Leyreloup, A.F., 1990. High temperature-low pressure Cretaceous metamorphism related to crustal thinning (Eastern North Pyrenean Zone, France). Contrib. Mineral. Petrol. 104, 194-207. https://doi.org/10.1007/BF00306443

Golberg, J.-M., \& Maluski, H., 1988. Données nouvelles et mise au point sur l'âge du métamorphisme pyrénéen. Comptes Rendus Académie Sci. Sér. 2 Mécanique Phys. Chim. Sci. Univers Sci. Terre 306, 429-435.

Golberg, J.M., Maluski, H., \& Leyreloup, A.F., 1986. Petrological and age relationship between emplacement of magmatic breccia, alkaline magmatism, and static metamorphism in the North Pyrenean Zone. Tectonophysics 129, 275-290. https://doi.org/10.1016/0040-1951(86)90256-8

Gomez-Ortiz, D., Agarwal, B.N.P., Tejero, R., \& Ruiz, J., 2011. Crustal structure from gravity signatures in the Iberian Peninsula. Geol. Soc. Am. Bull. 123, 1247-1257. https://doi.org/10.1130/B30224.1

Gómez-Romeu, J., Masini, E., Tugend, J., Ducoux, M., \& Kusznir, N., 2019. Role of rift structural inheritance in orogeny highlighted by the Western Pyrenees case-study. Tectonophysics 766, 131-150. https://doi.org/10.1016/j.tecto.2019.05.022

Gottis, M., 1972. Construction d'un modèle géodynamique pyrénéen. Comptes Rendus Académie Sci. 275, 2099.

Gong, Z., C. G. Langereis, and T. A. T. Mullender, 2008, The rotation of Iberia during the Aptian and the opening of the Bay of Biscay: Earth and Planetary Science Letters, v. 273, no. 1-2, p. 80-93, doi:10.1016/j.eps1.2008.06.016. 
Grandjean, G., 1994. Etude des structures crustales dans une portion de chaîne et de leur relation avec les bassins sédimentaires. Application aux Pyrénées occidentales. Bull Cent Rech Explor Prod Elf Aquitaine 18, 391-420.

Guimerà, J., Alonso, Á., \& Mas, J.R., 1995. Inversion of an extensional-ramp basin by a newly formed thrust: the Cameros basin (N. Spain). Geol. Soc. Lond. Spec. Publ. 88, 433-453. https://doi.org/10.1144/GSL.SP.1995.088.01.23

Guiraud, M., \& Séguret, M., 1985. A releasing solitary overstep model for the Late JurassicEarly Cretaceous (Wealdian) Soria strike-slip basin (northern Spain). AAPG Bull.

Hart, N.R., Stockli, D.F., Lavier, L.L., \& Hayman, N.W., 2017. Thermal evolution of a hyperextended rift basin, Mauléon Basin, western Pyrenees: Thermal evolution of hyperextended rift. Tectonics. https://doi.org/10.1002/2016TC004365

Henry, J., Zolnaï, G., Le Pochat, G., \& Mondeilh, C., 1987. Carte géologique de la France au 1/50 000: feuille d'Orthez, Orléans, France.

Huismans, R.S., \& Beaumont, C., 2003. Symmetric and asymmetric lithospheric extension: Relative effects of frictional-plastic and viscous strain softening. J. Geophys. Res. Solid Earth 108. https://doi.org/10.1029/2002JB002026

Huismans, R.S., \& Beaumont, C., 2008. Complex rifted continental margins explained by dynamical models of depth-dependent lithospheric extension. Geology 36, 163. https://doi.org/10.1130/G24231A.1

Huismans, R.S., \& Beaumont, C., 2011. Depth-dependent extension, two-stage breakup and cratonic underplating at rifted margins. Nature 473, 74-78. https://doi.org/10.1038/nature09988

Huismans, R.S., \& Beaumont, C., 2014. Rifted continental margins: The case for depthdependent extension. Earth Planet. Sci. Lett. 407, 148-162. https://doi.org/10.1016/j.eps1.2014.09.032

Incerpi, N., Manatschal, G., Martire, L., Bernasconi, S. M., Gerdes, A., Bertok, C., 2020. Characteristics and timing of hydrothermal fluid circulation in the fossil Pyrenean hyperextended rift system: new constraints from the Chaînons Béarnais (W Pyrenees). International Journal of Earth Sciences. https://doi.org/10.1007/s00531-020-01852-6

Issautier, B., Saspiturry, N., Serrano, O., 2020. Structural inheritance and salt tectonics controlling pseudosymmetric rift formation during Early Cretaceous hyperextension of the Arzacq and Tartas Basins (southwest France). Marine and Petroleum Geology. 10.1016/j.marpetgeo.2020.104395

Jackson, M. P., \& Hudec, M. R. (2005). Stratigraphic record of translation down ramps in a passive-margin salt detachment. Journal of Structural Geology, 27(5), 889-911. https://doi.org/10.1016/j.jsg.2005.01.010

James, V., 1998. La plate-forme carbonatée ouest-pyrénéenne au jurassique moyen et supérieur stratigraphie séquentielle, stades d'évolution, relations avec la subsurface en aquitaine méridionale.

James, V., \& Canérot, J., 1999. Diapirisme et structuration post-triasique des Pyrénées occidentales et de l'Aquitaine méridionale (France). Eclogae Geol. Helvetiae 92, 6372.

Jammes, S., 2009. Processus d'amincissement crustal en contexte transtensif : l'exempe du Golfe de Gascogne et des Pyrénées basques. PhD thesis, Strasbourg University.

Jammes, S., Manatschal, G., Lavier, L., \& Masini, E., 2009. Tectono-sedimentary evolution related to extreme crustal thinning ahead of a propagating ocean: Example of the western Pyrenees. Tectonics 28. https://doi.org/10.1029/2008TC002406

Jammes, S., Tiberi, C., \& Manatschal, G., 2010a. 3D architecture of a complex transcurrent rift system: The example of the Bay of Biscay-Western Pyrenees. Tectonophysics 489, 210-226. https://doi.org/10.1016/j.tecto.2010.04.023 
Jammes, S., Lavier, L., \& Manatschal, G., 2010b. Extreme crustal thinning in the Bay of Biscay and the Western Pyrenees: From observations to modeling. Geochem. Geophys. Geosystems 11. https://doi.org/10.1029/2010GC003218

Jammes, S., Manatschal, G., \& Lavier, L., 2010c. Interaction between prerift salt and detachment faulting in hyperextended rift systems: The example of the Parentis and Mauléon basins (Bay of Biscay and western Pyrenees). AAPG Bull. 94, 957-975. https://doi.org/10.1306/12090909116

Jiménez-Munt, I., Fernàndez, M., Vergés, J., Afonso, J.C., Garcia-Castellanos, D., \& Fullea, J., 2010. Lithospheric structure of the Gorringe Bank: Insights into its origin and tectonic evolution: GORRINGE BANK STRUCTURE AND EVOLUTION. Tectonics 29, n/a-n/a. https://doi.org/10.1029/2009TC002458

Labaume, P., \& Teixell, A., 2020. Evolution of salt structures of the Pyrenean rift (Chaînons Béarnais, France): From hyper-extension to tectonic inversion. Tectonophysics. https://doi.org/10.1016/j.tecto.2020.228451.

Lagabrielle, Y., \& Bodinier, J.-L., 2008. Submarine reworking of exhumed sub-continental mantle rocks: field evidence from the Lherz peridotites, French Pyrenees: Cretaceous exhumation of pyrenean mantle. Terra Nova 20, 11-21. https://doi.org/10.1111/j.1365-3121.2007.00781.x

Lagabrielle, Y., Labaume, P., \& de Saint Blanquat, M., 2010. Mantle exhumation, crustal denudation, and gravity tectonics during Cretaceous rifting in the Pyrenean realm (SW Europe): Insights from the geological setting of the lherzolite bodies. Tectonics 29. https://doi.org/10.1029/2009TC002588

Lagabrielle, Y., Clerc, C., Vauchez, A., Lahfid, A., Labaume, P., Azambre, B., Fourcade, S., \& Dautria, J.-M., 2016. Very high geothermal gradient during mantle exhumation recorded in mylonitic marbles and carbonate breccias from a Mesozoic Pyrenean palaeomargin (Lherz area, North Pyrenean Zone, France). Comptes Rendus Geosci. 348, 290-300. https://doi.org/10.1016/j.crte.2015.11.004

Lagabrielle, Y., Asti, R., Fourcade, S., Corre, B., Poujol, M., Uzel, J., . . Maury, R., 2019a. Mantle exhumation at magma-poor passive continental margins. Part I. 3D architecture and metasomatic evolution of a fossil exhumed mantle domain (Urdach lherzolite, north-western Pyrenees, France). BSGF - Earth Sci. Bull. 190, 8. https://doi.org/ 10.1016/j.earscirev.2019.103071.

Lagabrielle, Y., Asti, R., Duretz, T., Clerc, C., Fourcade, S., Teixell, A., . . Saspiturry, N., 2020. A review of cretaceous smooth-slopes extensional basins along the IberiaEurasia plate boundary: How pre-rift salt controls the modes of continental rifting and mantle exhumation. $\quad$ Earth-Science 201. https://doi.org/10.1051/bsgf/2019007

Lamare, P., 1936. Recherches géologiques dans les Pyrénées basques d'Espagne. Société géologique de France.

Lavier, L.L., \& Manatschal, G., 2006. A mechanism to thin the continental lithosphere at magma-poor margins. Nature 440, 324-328. https://doi.org/10.1038/nature04608

Le Pochat, G., Bolthenhagen, C., Lenguin, M., Lorsignol, S., \& Thibault, C., 1976. Carte géologique de France au 1/50 000: Mauléon-licharre, Orléans, France.

Lefort, J.-P., \& Agarwal, B.N.., 1999. Of what is the centre of the Ibero-Armorican arc composed? Tectonophysics 302, 71-81. https://doi.org/10.1016/S00401951(98)00275-3

Lemoine, M., Tricart, P., \& Boillot, G., 1987. Ultramafic and gabbroic ocean floor of the Ligurian Tethys (Alps, Corsica, Apennines): In search of a genetic imodel. Geology 15, 622-625. https://doi.org/10.1130/0091-7613(1987)15<622:UAGOFO>2.0.CO;2 
Lenoble, J.-L., 1992. Les plates-formes carbonatées ouest-pyrénéennes du dogger à l'Albien, stratigraphie séquentielle et évolution géodynamique. Université Paul Sabatier de Toulouse (Sciences).

Lescoutre, R., 2019. Formation and reactivation of the Pyrenean-Cantabrian rift system: inheritance, segmentation and thermal evolution. Strasbourg.

Lescoutre, R., Tugend, J., Brune, S., Masini, E., \& Manatschal, G., 2019. Thermal Evolution of Asymmetric Hyperextended Magma-Poor Rift Systems: Results From Numerical Modeling and Pyrenean Field Observations. Geochem. Geophys. Geosystems 2019GC008600. https://doi.org/10.1029/2019GC008600

Liro, L.M., \& Coen, R., 1995. Salt deformation history and postsalt structural trends, offshore southern Gabon, West Africa.

Lucas, C., 1985. Le grès rouge du versant nord des Pyrénées: essai sur la géodynamique de dépôts continentaux du permien et du trias.

Lundin, E.R., 1992. Thin-skinned extensional tectonics on a salt detachment, northern Kwanza Basin, Angola. Mar. Pet. Geol. 9, 405-411.

Manatschal, G., 2004. New models for evolution of magma-poor rifted margins based on a review of data and concepts from West Iberia and the Alps. Int. J. Earth Sci. 93. https://doi.org/10.1007/s00531-004-0394-7

Manatschal, G., Engström, A., Desmurs, L., Schaltegger, U., Cosca, M., Müntener, O., \& Bernoulli, D., 2006. What is the tectono-metamorphic evolution of continental breakup: The example of the Tasna Ocean-Continent Transition. J. Struct. Geol. 28, 18491869. https://doi.org/10.1016/j.jsg.2006.07.014

Manatschal, G., \& Nievergelt, P., 1997. A continent-ocean transition recorded in the Err and Platta nappes (Eastern Switzerland). Eclogae Geol. Helvetiae 90, 3-28.

Marillier, F., Tomassino, A., Patriat, P., \& Pinet, B., 1988. Deep structure of the Aquitaine shelf: constraints from expanding spread profiles on the ECORS Bay of Biscay transect. Mar. Pet. Geol. 5, 65-74.

Martínez-Torres, L.M., 1989. El manto de los mármoles (Pirineo occidental): geología estructural y evolución geodinámica (PhD Thesis). Universidad del País Vasco-Euskal Herriko Unibertsitatea.

Mas, J.R., Alonso, A., \& Guimerà, J., 1993. Evolución tectonosedimentaria de una cuenca extensional intraplaca: la cuenca finijurásica-eocretácica de Los Cameros (La RiojaSoria). Rev. Soc. Geológica Esp. 6, 129-144.

Mas, R., Benito, M.I., Arribas, J., Alonso, A., Arribas, M.E., Lohmann, K.C., . . . Suárez, P., 2011. Evolution of an intra-plate rift basin: the latest Jurassic-early Cretaceous Cameros basin (Northwest Iberian ranges, North Spain). Geo-Guías 8, 117-154.

Masini, E., Manatschal, G., Mohn, G., Ghienne, J.-F., \& Lafont, F., 2011. The tectonosedimentary evolution of a supra-detachment rift basin at a deep-water magma-poor rifted margin: the example of the Samedan Basin preserved in the Err nappe in SE Switzerland: Tectono-sedimentary evolution of a supra-detachment rift basin. Basin Res. 23, 652-677. https://doi.org/10.1111/j.1365-2117.2011.00509.x

Masini, E., Manatschal, G., Tugend, J., Mohn, G., \& Flament, J.-M., 2014. The tectonosedimentary evolution of a hyper-extended rift basin: the example of the ArzacqMauléon rift system (Western Pyrenees, SW France). Int. J. Earth Sci. 103, 15691596. https://doi.org/10.1007/s00531-014-1023-8

Mata, M.P., Casas, A.M., Canals, A., Gil, A., \& Pocovi, A., 2001. Thermal history during Mesozoic extension and Tertiary uplift in the Cameros Basin, northern Spain. Basin Res. 13, 91-111.

Mathieu, C., 1986. Histoire géologique du sous-bassin de Parentis. Bull. Cent. Rech. Explor. Elf-Aquitaine 10, 22-47. 
Mattauer, M., 1968. Les traits structuraux essentiels de la chaîne Pyrénéenne. Rev. Géologie Dyn. Géographie Phys. 10, 3-11.

Mauriaud, P., 1987. La tectonique salifère d'Aquitaine. Le bassin d'Aquitaine. Rev. Pétrole Tech. 335, 38-41.

Mediavilla, F., 1987. La tectonique salifère d'Aquitaine. Le Bassin de Parentis. Rev. Pétrole Tech. 335, 35-37.

Mendia, M.S., \& Ibarguchi, J.I.G., 1991. High-grade metamorphic rocks and peridotites along the Leiza Fault (Western Pyrenees, Spain). Geol. Rundsch. 80, 93-107.

Mohn, G., Karner, G.D., Manatschal, G., \& Johnson, C.A., 2015. Structural and stratigraphic evolution of the Iberia-Newfoundland hyper-extended rifted margin: a quantitative modelling approach. Geol. Soc. Lond. Spec. Publ. 413, 53-89. https://doi.org/10.1144/SP413.9

Monchoux, P., 1970. Les lherzolites pyrénéennes: contribution à l'étude de leur minéralogie, de leur genèse et de leurs transformations. Université Paul Sabatier de Toulouse (Sciences).

Montadert, L., de Charpal, O., Roberts, D., Guennoc, P., \& Sibuet, J.-C., 1979. Northeast Atlantic passive continental margins: Rifting and subsidence processes, in: Talwani, M., Hay, W., Ryan, W.B.F. (Eds.), Maurice Ewing Series. American Geophysical Union, Washington, D. C., pp. 154-186. https://doi.org/10.1029/ME003p0154

Montadert, L., \& Winnock, E., 1971. L'histoire structurale du Golf de Gascogne. Technip.

Montigny, R., Azambre, B., Rossy, M., \& Thuizat, R., 1986. K-Ar Study of cretaceous magmatism and metamorphism in the Pyrenees: Age and length of rotation of the Iberian Peninsula. Tectonophysics, The Geological Evolution of the Pyrenees 129, 257-273. https://doi.org/10.1016/0040-1951(86)90255-6

Nebot, M., \& Guimerà, J.J., 2016. Structure of an inverted basin from subsurface and field data: the Late Jurassic-Early Cretaceous Maestrat Basin (Iberian Chain). Geol. Acta 14, 0155-177.

Nirrengarten, M., Manatschal, G., Tugend, J., Kusznir, N., Sauter, D., 2017. Kinematic evolution of the southern North Atlantic: implications for the formation of hyperextended rift systems: Kinematic of hyper-extended rift systems. Tectonics. 37. 10.1002/2017TC004495

Olivier, P., Gleizes, G., \& Paquette, J.L., 2004. Gneiss domes and granite emplacement in an obliquely convergent regime: New interpretation of the Variscan Agly Massif (Eastern Pyrenees, France). Spec. Pap.-Geol. Soc. Am. 229-242.

Omodeo-Salé, S., Guimerà, J., Mas, R., \& Arribas, J., 2014. Tectono-stratigraphic evolution of an inverted extensional basin: the Cameros Basin (north of Spain). Int. J. Earth Sci. 103, 1597-1620. https://doi.org/10.1007/s00531-014-1026-5

Omodeo-Salé, S., Salas, R., Guimerà, J., Ondrak, R., Mas, R., Arribas, J., Suárez-Ruiz, I., \& Martinez, L., 2017. Subsidence and thermal history of an inverted Late Jurassic-Early Cretaceous extensional basin (Cameros, North-central Spain) affected by very low- to low-grade metamorphism. Basin Res. 29, 156-174. https://doi.org/10.1111/bre.12142

Ortí, F., 1974. El Keuper del levante español. Estud. Geológicos 30, 7-46.

Ortí, F., Pérez-López, A., \& Salvany, J.M., 2017. Triassic evaporites of Iberia: Sedimentological and palaeogeographical implications for the western Neotethys evolution during the Middle Triassic-Earliest Jurassic. Palaeogeogr. Palaeoclimatol. Palaeoecol. 471, 157-180. https://doi.org/10.1016/j.palaeo.2017.01.025

Osmundsen, P.T., \& Ebbing, J., 2008. Styles of extension offshore mid-Norway and implications for mechanisms of crustal thinning at passive margins: STYLES OF EXTENSION OFFSHORE NORWAY. Tectonics 27, n/a-n/a. https://doi.org/10.1029/2007TC002242 
Osmundsen, P.T., \& Péron-Pinvidic, G., 2018. Crustal-Scale Fault Interaction at Rifted Margins and the Formation of Domain-Bounding Breakaway Complexes: Insights From Offshore Norway. Tectonics 37, 935-964. https://doi.org/10.1002/2017TC004792

Osmundsen, P.T., Sommaruga, A., Skilbrei, J.R., \& Olesen, O., 2002. Deep structure of the Mid Norway rifted margin. Nor. J. Geol. Geol. Foren. 82.

Pedreira, D., Pulgar, J.A., Gallart, J., \& Torné, M., 2007. Three-dimensional gravity and magnetic modeling of crustal indentation and wedging in the western PyreneesCantabrian Mountains. J. Geophys. Res. 112. https://doi.org/10.1029/2007JB005021

Pedrera, A., García-Senz, J., Ayala, C., Ruiz-Constán, A., Rodríguez-Fernández, L.R., Robador, A., \& González Menéndez, L., 2017. Reconstruction of the exhumed mantle across the North Iberian Margin by crustal-scale 3-D gravity inversion and geological cross section. Tectonics 36, 3155-3177.

Pedrera, A., García-Senz, J., Peropadre, C., Robador, A., Lopez Mir, B., Diaz Alvarado, J., \& Rodríguez-Fernández, L.R., 2020. The Getxo crustal-scale cross-section: testing tectonic models in the Bay of Biscay-Pyrenean rift system. Earth-Sciences Review, doi: 10.1016/j.earscirev.2020.103429.

Pereira, R., Alves, T.M., 2012, Tectono-stratigraphic signature of multiphased rifting on divergent margins (deep-offshore Southwest Iberia, North Atlantic). Tectonics. 31. doi:10.1029/2011TC003001

Pérez-Gussinyé, M., 2013. A tectonic model for hyperextension at magma-poor rifted margins: an example from the West Iberia-Newfoundland conjugate margins. Geol. Soc. Lond. Spec. Publ. 369, 403-427. https://doi.org/10.1144/SP369.19

Péron-Pinvidic, G., Manatschal, G., Masini, E., Sutra, E., Flament, J.M., Haupert, I., \& Unternehr, P., 2015. Unravelling the along-strike variability of the Angola-Gabon rifted margin: a mapping approach. Geol. Soc. Lond. Spec. Publ. 438, 49-76. https://doi.org/10.1144/SP438.1

Péron-Pinvidic, G., Manatschal, G., Minshull, T.A., \& Sawyer, D.S., 2007. Tectonosedimentary evolution of the deep Iberia-Newfoundland margins: Evidence for a complex breakup history. Tectonics 26, 1-19. https://doi.org/10.1029/2006TC001970

Peybernès, B., 1976. Le Jurassique et le Crétace inferieur des Pyrénées franco-espagnoles entre la Garonne et la Méditérranée. Toulouse.

Peybernès, B., 1979. L’Urgonien des Pyrénées, Essai de synthèse. Geobios 12, 79-87.

Peybernès, B., 1982. Création puis évolution de la marge nord-ibérique des Pyrénées au Crétacé inférieur. Cuad. Geol. Ibérica 8, 987-1004.

Peybernès, B., \& Combes, P.-J., 1994. Stratigraphie séquentielle du Crétacé basal (intervalle Berriasien-Hauterivien) des Pyrénées centrales et orientales franco-espagnoles. Cretac. Res. 15, 535-546. https://doi.org/10.1006/cres.1994.1032

Pichel, L. M., Peel, F., Jackson, C. A.-L., \& Huuse, M. (2018). Geometry and kinematics of salt-detached ramp syncline basins. Journal of Structural Geology, 115, 208-230. https://doi.org/10.1016/j.jsg.2018.07.016

Pichel, L. M., Finch, E., \& Gawthorpe, R. L. (2019). The Impact of Pre-Salt Rift Topography on Salt Tectonics: A Discrete-Element Modeling Approach. Tectonics, 38(4), 14661488 .

Pinet, B., Montadert, L., Curnelle, R., Cazes, M., Marillier, F., Rolet, J., . . . Brunet, M.F., 1987a. Crustal thinning on the Aquitaine shelf, Bay of Biscay, from deep seismic data. Nature 325, 513. 
Pinet, Bertrand, Montadert, L., \& ECORS Scientific Party, 1987b. Deep seismic reflection and refraction profiling along the Aquitaine shelf (Bay of Biscay). Geophys. J. Int. 89, 305-312. https://doi.org/10.1111/j.1365-246X.1987.tb04423.x

Platt, N.H., 1986. Sedimentology and Tectonics of the Western Cameros Basin, Province of Burgos, Northern Spain (PhD Thesis). University of Oxford.

Platt, N.H., 1989. Continental sedimentation in an evolving rift basin: the Lower Cretaceous of the western Cameros Basin (northern Spain). Sediment. Geol. 64, 91-109. https://doi.org/10.1016/0037-0738(89)90086-9

Platt, N.H., 1990. Basin evolution and fault reactivation in the western Cameros Basin, Northern Spain. J. Geol. Soc. 147, 165-175. https://doi.org/10.1144/gsjgs.147.1.0165

Quijada, I.E., Suárez González, P., Isabel, B.M., Mas, J.R., \& Alonso, Á., 2010. Un ejemplo de llanura fluvio-deltaica influenciada por las mareas: el yacimiento de icnitas de Serrantes (Grupo Oncala, Berriasiense, Cuenca de Cameros, N. de España). Geogaceta $15-18$.

Rat, J., Mouthereau, F., Brichau, S., Crémades, A., Bernet, M., Balvay, M., . . Gautheron, C., 2019. Tectonothermal Evolution of the Cameros Basin: Implications for Tectonics of North Iberia. Tectonics 38, 440-469. https://doi.org/10.1029/2018TC005294

Rat, P., 1988. The Basque-Cantabrian Basin between the Iberian and European plates, some facts but still many problems. Rev Soc Geol Esp. 327-348.

Rat, P., Amiot, M., Feuillée, P., Floquet, M., Mathey, B., Pascal, A., . . Lamolda, M., others, 1983. Vue sur le Cretacé basco-cantabrique et nord-ibérique. Une Marge Son ArrierePays Ses Environ. Sedimentaires Memoires Geol. Univ. Dijon 9, 191.

Ravier, J., 1957. Le métamorphisme des terrains secondaires des Pyrénées. Université, Faculté des Sciences.

Razin, P., 1989, Evolution tecto-sédimentaire alpine des Pyrénées basques à l'ouest de la transformante de Pamplona, Province du Labourd. PhD thesis, University of Bordeaux 3, France, $464 \mathrm{p}$.

Reston, T.J., 2009. The structure, evolution and symmetry of the magma-poor rifted margins of the North and Central Atlantic: A synthesis. Tectonophysics 468, 6-27. https://doi.org/10.1016/j.tecto.2008.09.002

Reston, T.J., Krawczyk, C.M., \& Hoffmann, H.-J., 1995. Detachment tectonics during Atlantic rifting: analysis and interpretation of the $\mathrm{S}$ reflection, the west Galicia margin. Geol. Soc. Lond. Spec. Publ. 90, 93-109. https://doi.org/10.1144/GSL.SP.1995.090.01.05

Ribes, C., Ghienne, J.-F., Manatschal, G., Decarlis, A., Karner, G.D., Figueredo, P.H., \& Johnson, C.A., 2019. Long-lived mega fault-scarps and related breccias at distal rifted margins: Insights from present-day and fossil analogues. J. Geol. Soc. jgs2018-181. https://doi.org/10.1144/jgs2018-181

Roca, E., 1996. La cubeta mesozoica de las Columbrets: aportaciones al conocimiento de la estructura del surco de Valencia. Geogaceta 20, 1711-1714.

Roma, M., Ferrer, O., Roca, E., Pla, O., Escosa, F.O., \& Butillé, M., 2018. Formation and inversion of salt-detached ramp-syncline basins. Results from analog modeling and application to the Columbrets Basin (Western Mediterranean). Tectonophysics 745, 214-228. https://doi.org/10.1016/j.tecto.2018.08.012

Rossi, P., Cocherie, A., Fanning, C.M., \& Ternet, Y., 2003. Datation U-Pb sur zircons des dolérites tholéiitiques pyrénéennes (ophites) à la limite Trias-Jurassique et relations avec les tufs volcaniques dits «infra-liasiques» nord-pyrénéens. Comptes Rendus Geosci. 335, 1071-1080. https://doi.org/10.1016/j.crte.2003.09.011 
Rouby, D., Raillard, S., Guillocheau, F., Bouroullec, R., \& Nalpas, T., 2002. Kinematics of a growth fault/raft system on the West African margin using 3-D restoration. J. Struct. Geol. 24, 783-796.

Roux, J.-C., 1983. Recherches stratigraphiques et sédimentologiques sur les flyschs crétacés pyrénéens au sud d'Oloron (Pyrénées Atlantiques). Université Paul Sabatier de Toulouse (Sciences).

Ruiz, M., 2007. Caracterització estructural i sismotectònica de la litosfera en el domini Pirenaico-Cantàbric a partir de mètodes de sísmica activa i passiva. Universitat de Barcelona.

Sàbat, F., Roca, E., Muñoz, J.A., Vergès, J., Santanach, P., \& Masana, E., 1997. Role of extension and compression in the evolution of the eastern margin of Iberia: The ESCIValència trough seismic profile. Rev. Soc. Geológica Esp. 8, 431-448.

Salas, R., Guimerà, J., Mas, R., Martín-Closas, C., Meléndez, A., \& Alonso, A., 2001. Evolution of the Mesozoic central Iberian Rift System and its Cainozoic inversion (Iberian chain). Peri-Tethys Mem. 6, 145-185.

Saspiturry, N., Cochelin, B., Razin, P., Leleu, S., Lemirre, B., Bouscary, C., . . Allanic, C., 2019a. Tectono-sedimentary evolution of a rift system controlled by Permian postorogenic extension and metamorphic core complex formation (Bidarray Basin and Ursuya dome, Western Pyrenees). Tectonophysics 768, 228180. https://doi.org/10.1016/j.tecto.2019.228180

Saspiturry, N., Razin, P., Baudin, T., Serrano, O., Issautier, B., Lasseur, E., . . Leleu, S., 2019b. Symmetry vs. asymmetry of a hyper-thinned rift: Example of the Mauléon Basin (Western Pyrenees, France). Mar. Pet. Geol. 104, 86-105. https://doi.org/10.1016/j.marpetgeo.2019.03.031

Saspiturry, N., Razin, P., Allanic, C., Issautier, B., Baudin, T., Lasseur, E., . . Leleu, S., 2020a, Closure of a hyperextended system in an orogenic lithospheric pop-up, Western Pyrenees: The role of mantle buttressing and rift structural inheritance: Terra Nova. 10.1111/ter.12457.

Saspiturry, N., Lahfid, A., Baudin, T., Guillou-Frottier, G., Razin, P., Issautier, B., Le Bayon, B., Serrano, O., Lagabrielle, Y., Corre, B., 2020b. Paleogeothermal Gradients across an Inverted Hyperextended Rift System: Example of the Mauléon Fossil Rift (Western Pyrenees). Tectonics. 10.1029/2020TC006206

Saspiturry, N., 2019. Evolution sédimentaire, structurale et thermique d'un rift hyper-aminci : de l'héritage post-hercynien à l'inversion alpine, Exemple du bassin de Mauléon (Pyrénées). PhD thesis, Bordeaux University, 444p.

Schettino, A., \& Turco, E., 2011. Tectonic history of the western Tethys since the Late Triassic. Geol. Soc. Am. Bull. 123, 89-105. https://doi.org/10.1130/B30064.1

Serrano, O., Delmas, J., Hanot, F., Vially, R., Herbin, J.-P., Houel, P., \& Tourlière, B., 2006. Le bassin d'Aquitaine: valorisation des données sismiques, cartographie structurale et potentiel pétrolier. Bureau de Recherche Géologique et minière.

Soares, D.M., Alves, T.M., Terrinha, P., 2012. The breakup sequence and associated lithospheric breakup surface: their significance in the context of rifted continental margins (West Iberia and Newfoundland margins, North Atlantic). Earth Planet Sci.Lett. 355-356, 311-326. https://doi.org/10.1016/j.epsl.2012.08.036.

Soares, D.M., 2014. Sedimentological and stratigraphical aspects of the syn- to post-rift transition on fully separated conjugate margins. $\mathrm{PhD}$ thesis, Cardiff University. 305p.

Soto, J.I., Flinch, F., \& Tari, G., 2017. Permo-Triassic Salt Provinces of Europe, North Africa and the Atlantic Margins: Tectonics and Hydrocarbon Potential, in: In Soto et Al., Eds, Permo-Triassic Salt Provinces of Europe, North Africa and the Atlantic Margins. Tectonics and Hydrocarbon Potential. Elsevier. 
1774

1775

1776

1777

1778

1779

1780

1781

1782

1783

1784

1785

1786

1787

1788

1789

1790

1791

1792

1793

1794

1795

1796

1797

1798

1799

1800

1801

1802

1803

1804

1805

1806

1807

1808

1809

1810

1811

1812

1813

1814

1815

1816

1817

1818

1819

1820

1821

1822

Souquet, P., 1967. Le Crétacé supérieur Sud-Pyrénéen, en Catalogne, Aragon et Navarre. E. Privat.

Souquet, P., Debroas, E.-J., Boirie, J.-M., Pons, P., Fixari, G., Roux, J.-C., . . Manivit, H., others, 1985. Le groupe du Flysch noir (albo-cénomanien) dans les Pyrénées. Bull Cent Rech Exlpo-Prod Elf-Aquitaine Pau 9, 183-252.

Suárez González, P., Quijada, I.E., Mas, J.R., \& Benito, M.I., 2010. Nuevas aportaciones sobre la influencia marina y la edad de los carbonatos de la Fm Leza en el sector de Préjano (SE de La Rioja). Cretácico Inferior, Cuenca de Cameros. Geogaceta 7-10.

Teixell, A., Labaume, P., Ayarza, P., Espurt, N., de Saint Blanquat, M., \& Lagabrielle, Y., 2018. Crustal structure and evolution of the Pyrenean-Cantabrian belt: A review and new interpretations from recent concepts and data. Tectonophysics 724, 146-170. https://doi.org/10.1016/j.tecto.2018.01.009

Teixell, A., Labaume, P., \& Lagabrielle, Y., 2016. The crustal evolution of the west-central Pyrenees revisited: Inferences from a new kinematic scenario. Comptes Rendus Geosci. 348, 257-267. https://doi.org/10.1016/j.crte.2015.10.010

Ternet, Y., Majesté-Menjoulas, C., Canérot, J., Baudin, T., Cocherie, A., Guerrot, C., \& Rossi, P., 2004. Carte géologique de la France au 1/50 000: Laruns-Somport, Orléans, France.

Thiébaut, J., Durand-Wackenheim, C., Debeaux, M., \& Souquet, P., 1992. Métamorphisme des évaporites triasiques du versant nord des Pyrénées centrales et Occidentales. Bull. Société Hist. Nat. Toulouse 128, 77-84.

Thinon, I., 1999. Structure profonde de la marge Nord Gascogne et du Bassin armoricain. Université de Bretagne occidentale-Brest.

Thinon, I., Fidalgo-González, L., Réhault, J. P. and Olivet, J. L., 2001, Pyrenean deformations in the Bay of Biscay: Comptes Rendus de l'Académie des Sciences, Série IIa, v.332, p.561-568.

Thinon, I., Matias, L., Réhault, J.P., Hirn, A., Fidalgo-GonzÁlez, L., \& Avedik, F., 2003. Deep structure of the Armorican Basin (Bay of Biscay): a review of Norgasis seismic reflection and refraction data. J. Geol. Soc. 160, 99-116. https://doi.org/10.1144/0016764901-103

Tomassimo, A., \& Marillier, F., 1997. Processing and interpretation in the tau-p domain of the ECORS Bay of Biscay expanding spread profiles. Mém. Société Géologique Fr. 171, $31-43$.

Torné, M., Banda, E., \& Fernandez, M., 1996. The Valencia Trough: Geological and geophysical constraints on the basin formation model., in: In P. A. Ziegler, \& F. Horvath (Eds.), Structure and Prospects of Alpine Basins and Forelands, Mem. Nat Hist. Mus. pp. 103-128.

Torné, M., Pascal, G., Buhl, P., Watts, A.B., \& Mauffret, A., 1992. Crustal and velocity structure of the Valencia trough (western Mediterranean), Part I. A combined refraction/ wide-angle reflection and near-vertical reflection study. Tectonophysics 203, 1-20. https://doi.org/10.1016/0040-1951(92)90212-O

Tugend, J., Manatschal, G., Kusznir, N.J., \& Masini, E., 2015. Characterizing and identifying structural domains at rifted continental margins: application to the Bay of Biscay margins and its Western Pyrenean fossil remnants. Geol. Soc. Lond. Spec. Publ. 413, 171-203. https://doi.org/10.1144/SP413.3

Tugend, J., Manatschal, G., Kusznir, N.J., Masini, E., Mohn, G., \& Thinon, I., 2014. Formation and deformation of hyperextended rift systems: Insights from rift domain mapping in the Bay of Biscay-Pyrenees. Tectonics 33, 1239-1276. https://doi.org/10.1002/2014TC003529 
1823

1824

1825

1826

1827

1828

1829

1830

1831

1832

1833

1834

1835

1836

1837

1838

1839

1840

1841

1842

1843

1844

1845

1846

1847

1848

1849

1850

1851

1852

1853

1854

1855

1856

1857

1858

1859

1860

1861

1862

1863
Vacher, P., \& Souriau, A., 2001. A three-dimensional model of the Pyrenean deep structure based on gravity modelling, seismic images and petrological constraints. Geophys. J. Int. 145, 460-470. https://doi.org/10.1046/j.0956-540x.2001.01393.x

Vacherat, A., Mouthereau, F., Pik, R., Bernet, M., Gautheron, C., Masini, E., . . Lahfid, A., 2014. Thermal imprint of rift-related processes in orogens as recorded in the Pyrenees. Earth Planet. Sci. Lett. 408, 296-306. https://doi.org/10.1016/j.epsl.2014.10.014

Valladares, I., 1980. Evolución de facies en el Jurasico calcareo del sector sur-occidental de la provincia de Burgos. Stud. Geol. Salamanticensia 16, 37-57.

Vargas, H., Gaspar-Escribano, J.M., López-Gómez, J., Van Wees, J.-D., Cloetingh, S., de La Horra, R., \& Arche, A., 2009. A comparison of the Iberian and Ebro Basins during the Permian and Triassic, eastern Spain: A quantitative subsidence modelling approach. Tectonophysics 474, 160-183. https://doi.org/10.1016/j.tecto.2008.06.005

Vauchez, A., Clerc, C., Bestani, L., Lagabrielle, Y., Chauvet, A., Lahfid, A., \& Mainprice, D., 2013. Preorogenic exhumation of the North Pyrenean Agly massif (Eastern PyreneesFrance). Tectonics 32, 95-106. https://doi.org/10.1002/tect.20015

Vergés, J., \& García-Senz, J., 2001. Mesozoic evolution and Cenozoic inversion of the Pyrenean rift. Mém. Muséum Natl. Hist. Nat. 186, 187-212.

Vidal, N., Gallart, J., \& Dañobeitia, J.J., 1997. Contribution of the ESCI-Valencia Trough wide-angle data to a crustal transect in the NE Iberian margin. Rev. - Soc. Geológica Esp. 417-429.

Vielzeuf, D., \& Kornprobst, J., 1984. Crustal splitting and the emplacement of Pyrenean lherzolites and granulites. Earth Planet. Sci. Lett. 67, 87-96. https://doi.org/10.1016/0012-821X(84)90041-4

Wang, Y., Chevrot, S., Monteiller, V., Komatitsch, D., Mouthereau, F., Manatschal, G., . . . Martin, R., 2016. The deep roots of the western Pyrenees revealed by full waveform inversion of teleseismic $\mathrm{P}$ waves. Geology 44, 475-478. https://doi.org/10.1130/G37812.1

Whitmarsh, R.B., Manatschal, G., \& Minshull, T.A., 2001. Evolution of magma-poor continental margins from rifting to seafloor spreading. Nature 413, 150-154. https://doi.org/10.1038/35093085

Wilson, R. C. L., G. Manatschal, and S. Wise (2001), Rifting along non-volcanic passive margins: Stratigraphic and seismic evidence from the Mesozoic successions of the Alps and western Iberia, in Nonvolcanic Continental Margins: A Comparison of Evidence From Land and Sea, edited by R. C. L. Wilson et al., Geol. Soc. Spec. Publ., $187,29-452$.

Zeyen, H., \& Fernàndez, M., 1994. Integrated lithospheric modeling combining thermal, gravity, and local isostasy analysis: Application to the NE Spanish Geotransect. J. Geophys. Res. Solid Earth 99, 18089-18102. https://doi.org/10.1029/94JB00898

Ziegler, P.A., 1982. Triassic rifts and facies patterns in Western and Central Europe. Geol. Rundsch. 71, 747-772. https://doi.org/10.1007/BF01821101 


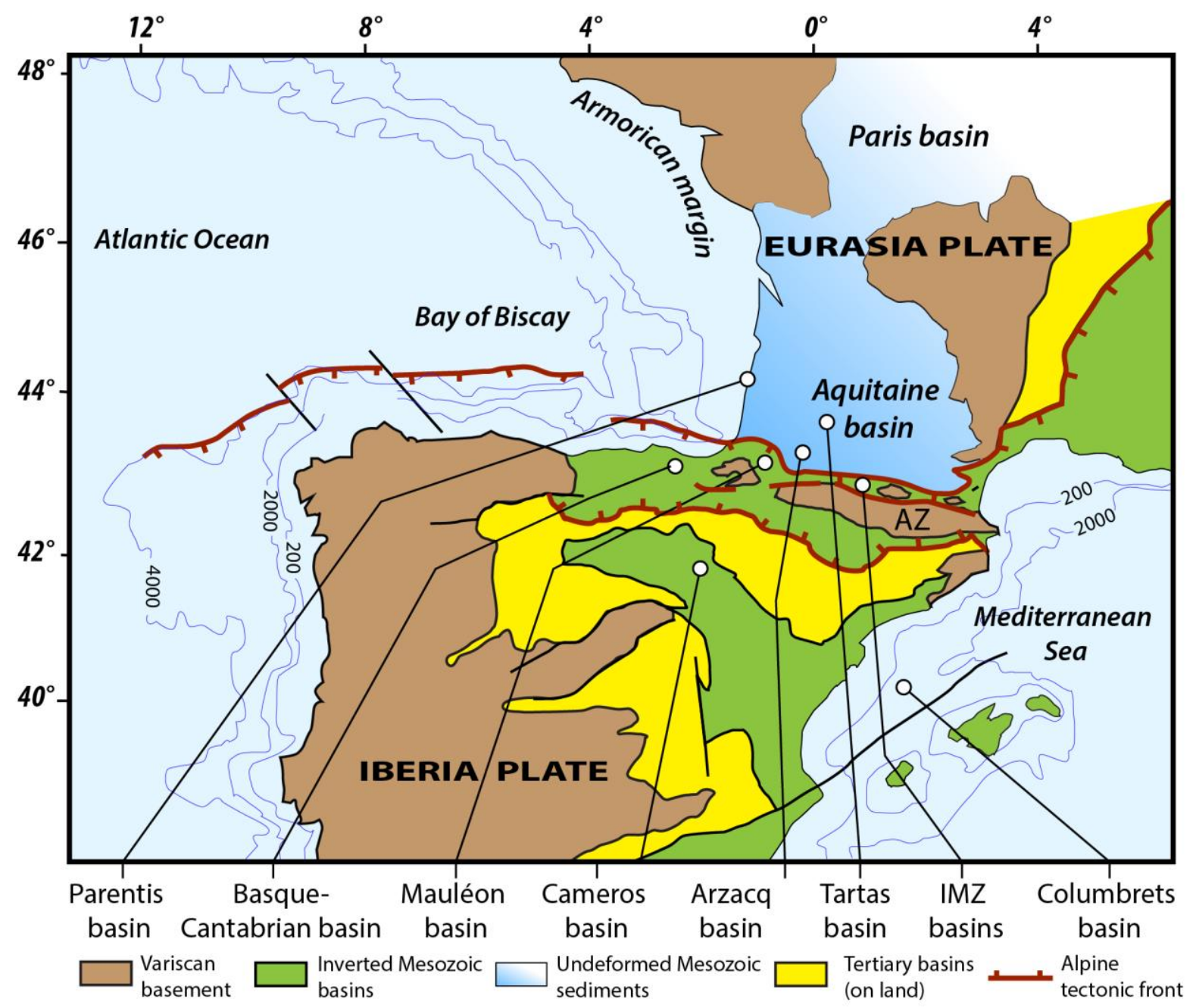

1866 FIGURE 1 Simplified structural map of the Cantabrian-Pyrenean orogenic system and

1867 adjoining Iberia showing deformed and undeformed domains in the Eurasia plate and the

1868 locations of basins in this study (modified from Lagabrielle et al., 2020). 

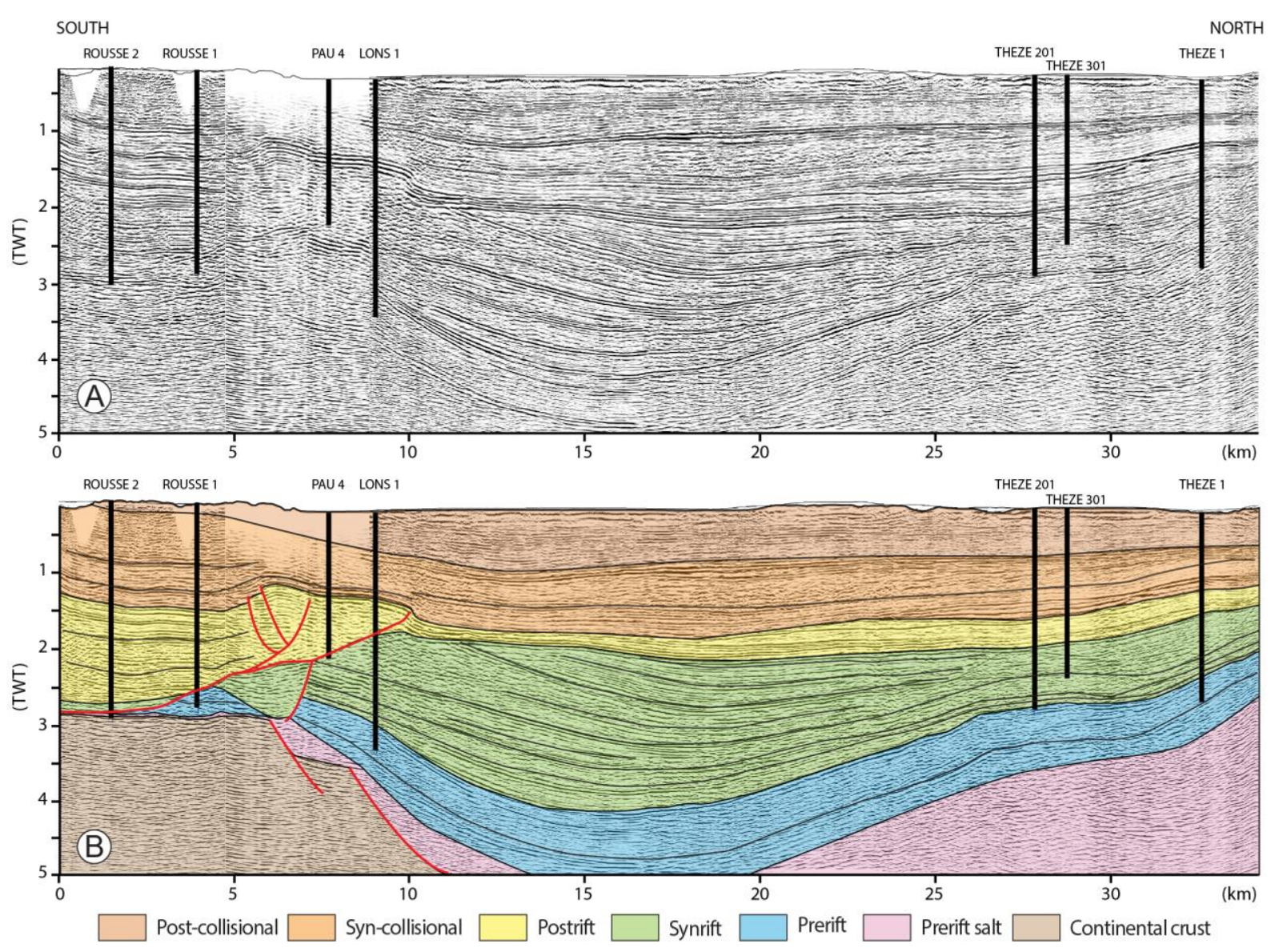

FIGURE 2 Interpretation of a South-North seismic reflection profile across the Arzacq basin:

1872 (A) Rousse-Thèze seismic reflection profile, calibrated using, from south to north, the

1873 Rousse-2, Rousse-1, Pau-4, Lons-1, Thèze 201, Thèze 301 and Thèze 1 boreholes (Issautier et

1874 al., 2020). (B) Interpreted section (modified from Issautier et al., 2020). The syn-rift sequence

1875 is characterized by a maximum time thickness of around 2.5 TWT seconds corresponding to a

1876 thickness of nearly $2000-3000 \mathrm{~m}$. The depocenter of the syn-rift sequence in the Arzacq basin

1877 migrates south from its position, indicating a northward salt-controlled cover gliding during

1878 the rifting stage. The Arzacq syn-rift basin is characterized by a slight asymmetry of its 1879 depocenter. 


\section{$1880 \quad$ Figure.3}
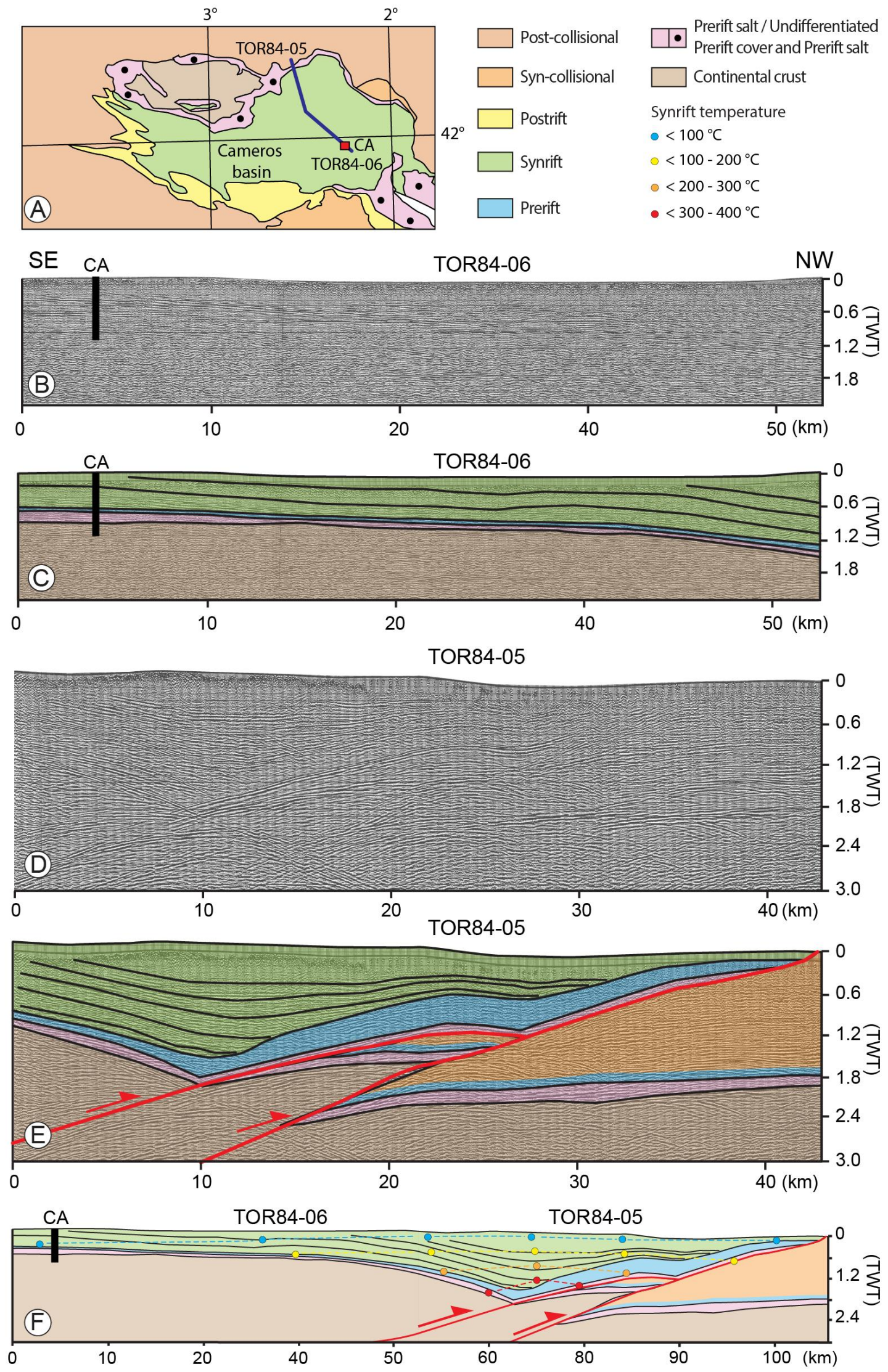
1882 FIGURE 3 (A) Geological map of the Cameros basin (modified from Omodeo-Salé et al.,

1883 2014); (B-C) Interpretation of the SE-NW TOR84-06 seismic reflection profiles across the 1884 Cameros basin, location on Figure 3A (Omodeo-Salé et al., 2014), CA: Castelfrio 1 borehole; 1885 (D-E) Interpretation of the SE-NW TOR84-05 seismic reflection profiles across the Cameros 1886 basin, location on Figure 3A (Omodeo-Salé et al., 2014). (F) Line-drawing of the TOR84-05 1887 and TOR84-06 seismic reflection profiles. The syn-rift sequence displays an onlap geometry 1888 on the marine Jurassic substrate towards the north. The depocenter of the syn-rift sequence in 1889 the Cameros basin migrates north from its position, indicating southward salt-controlled cover 1890 gliding during the rifting stage rooting at depth on a crustal structure. The Cameros syn-rift 1891 basin is characterised by a slight asymmetry of its depocenter. The syn-rift sequence is 1892 characterised by a maximum time thickness of around 1.5 TWT seconds corresponding to a 1893 thickness of nearly 1500-2000 m. Available syn-rift paleotemperatures from Rat et al. (2019) 1894 indicate that the base of the syn-rift basin reached temperatures of around $300-400{ }^{\circ} \mathrm{C}$. 


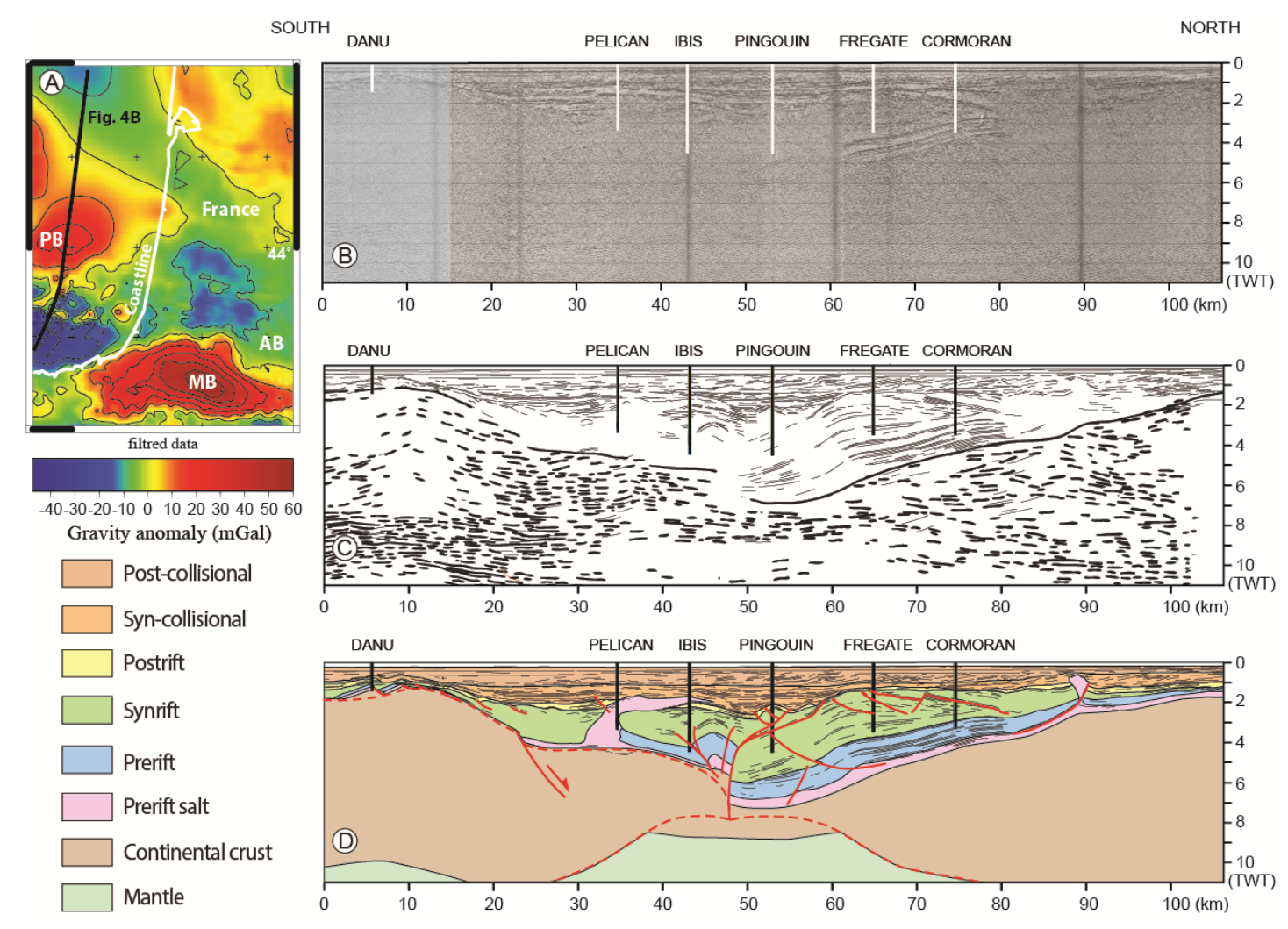

1897 FIGURE 4 Parentis basin architecture. (A) Filtered Bouguer gravity anomaly map (Jammes, 1898 2009); PB: Parentis basin Bouguer Anomaly; MB: Mauléon basin Bouguer Anomaly; AB: 1899 Arzacq basin. (B) Bay of Biscay ECORS profile, calibrated using, from south to north, the 1900 Danu, Pelican, Ibis, Pingouin, Fregate and Cormoran boreholes (in Jammes, 2009). (C) Line 1901 drawing of the sedimentary structures and deep crustal structures of the Bay of Biscay 1902 ECORS profile (in Jammes, 2009). (D) Interpreted Bay of Biscay ECORS profile (modified 1903 from Jammes, 2019). The depocenter of the syn-rift sequence in the Parentis basin migrates 1904 south from its position indicating northward salt-controlled cover gliding during the rifting 1905 stage, interpreted by Jammes (2009) and Tugend et al. (2014) as a northward-deepening 1906 décollement rooting at depth on a crustal detachment fault. The Parentis syn-rift basin is 1907 characterized by a mildly asymmetry of its depocenter. The syn-rift sequence is characterised 1908 by a maximum time thickness of around 4 TWT seconds corresponding to a thickness of 1909 nearly $3000-4500 \mathrm{~m}$. 

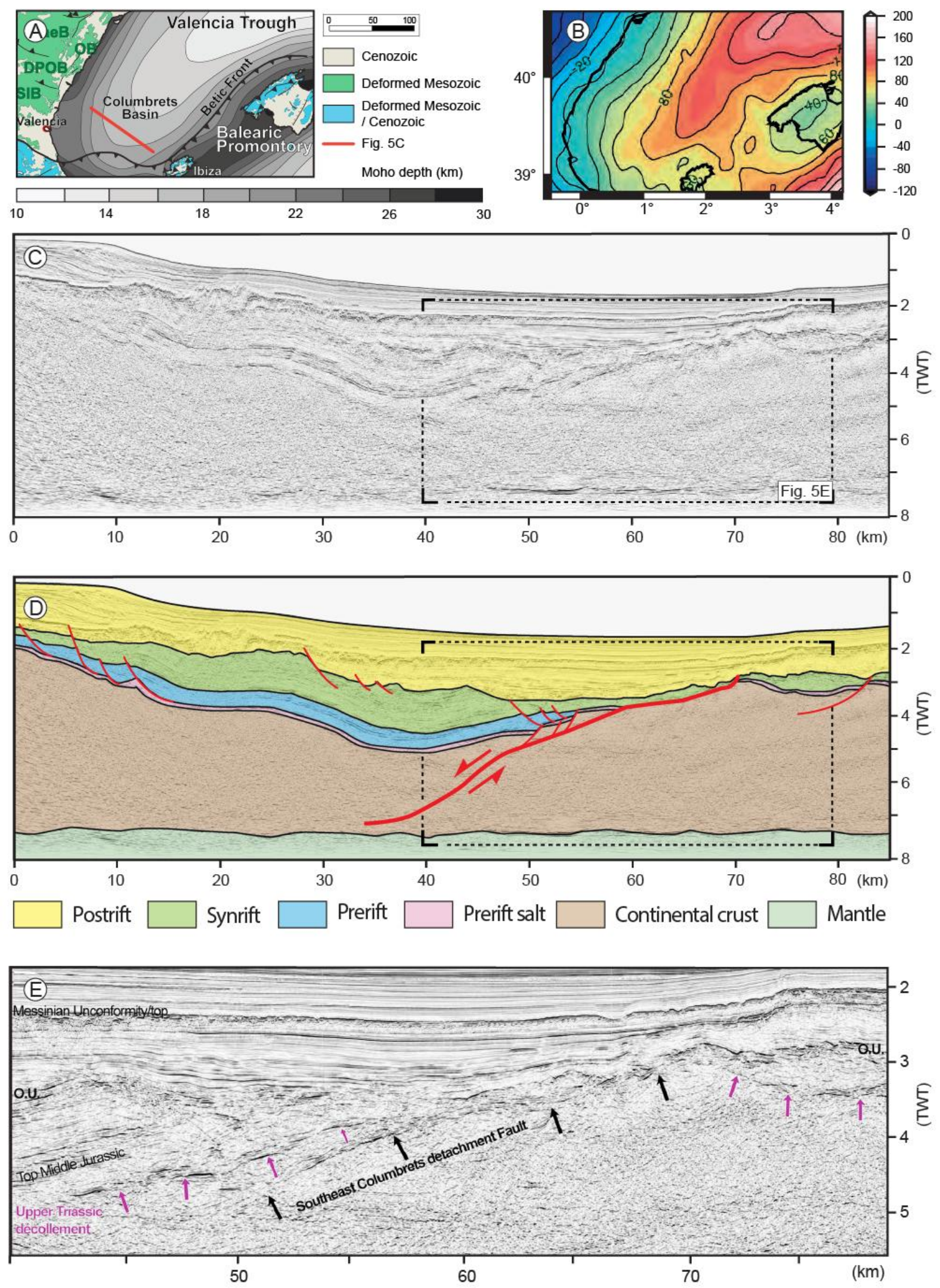
1912 FIGURE 5 (A) Geological and structural map of the Columbrets basin showing the Moho 1913 depth varying from 10 to $30 \mathrm{~km}$ depth (modified from Etheve et al., 2018). (B) Map of the

1914 Bouguer anomaly (modified from et al., 2015). (C) NW-SE SGV01-113 seismic reflection 1915 profile; location on Figure 5A (Etheve et al., 2018). (D) Interpreted SGV01-113 seismic 1916 reflection profile (modified from Etheve et al., 2018). The syn-rift sequence is characterised 1917 by a maximum time thickness of around 1.5 TWT seconds corresponding to a thickness of 1918 nearly 1500-2000 m; however, its true thickness was greater as the top of this sequence is 1919 affected by a major Tertiary erosional unconformity. The depocenter of the syn-rift sequence 1920 in the Columbrets basin migrates south from its position, indicating northward salt-controlled 1921 cover gliding during the rifting stage interpreted by Etheve et al. (2018) as a northward1922 deepening salt décollement rooting at depth on a ductile crustal detachment fault. (E) Detail of 1923 the southern part of the SGV01-113 seismic reflection profile showing the northward1924 deepening ductile crustal detachment fault (Etheve et al., 2018). 


\section{Figure.6}

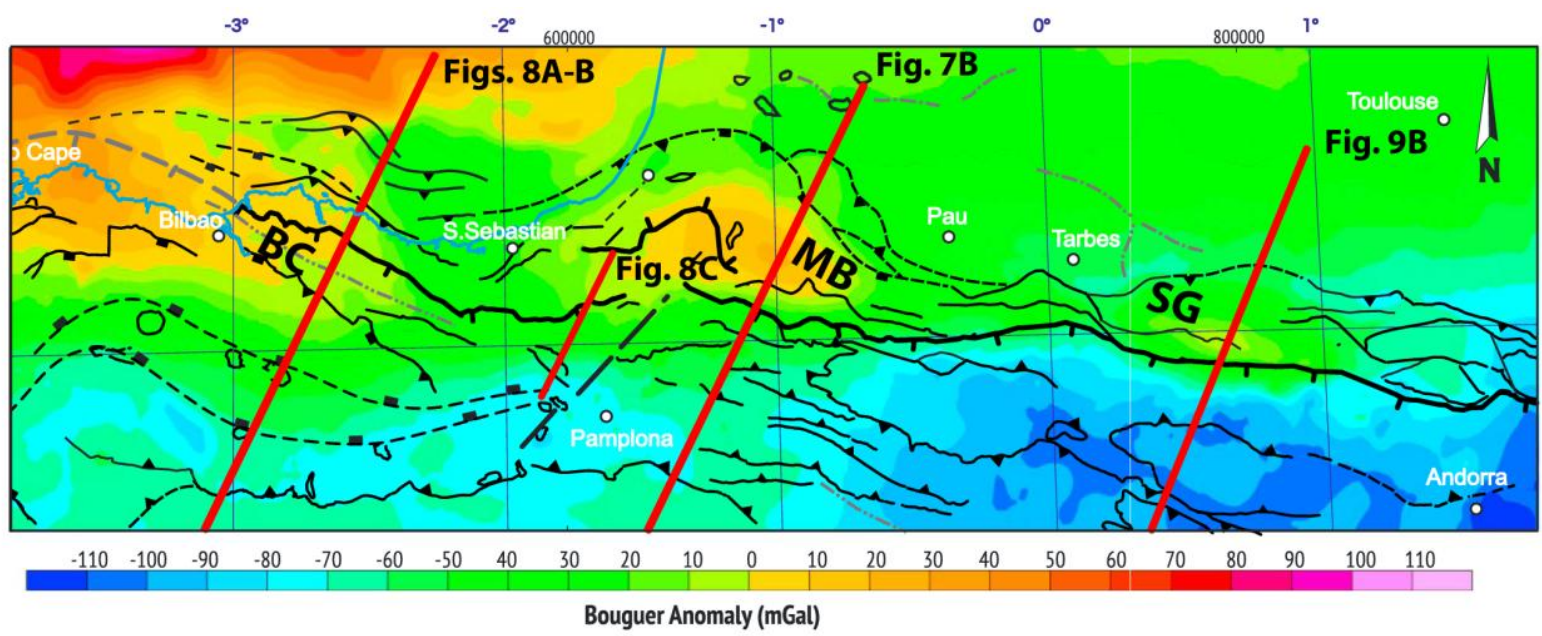

1927 FIGURE 6 Bouguer anomaly map from the Basque-Cantabrian basin to the Central Pyrenees

1928 (Pedrera et al., 2017). BC, Basque-Cantabrian Bouguer anomaly; MB, Mauléon basin

1929 Bouguer anomaly; SG, Saint-Gaudens Bouguer anomaly. 
$1930 \quad$ Figure.7

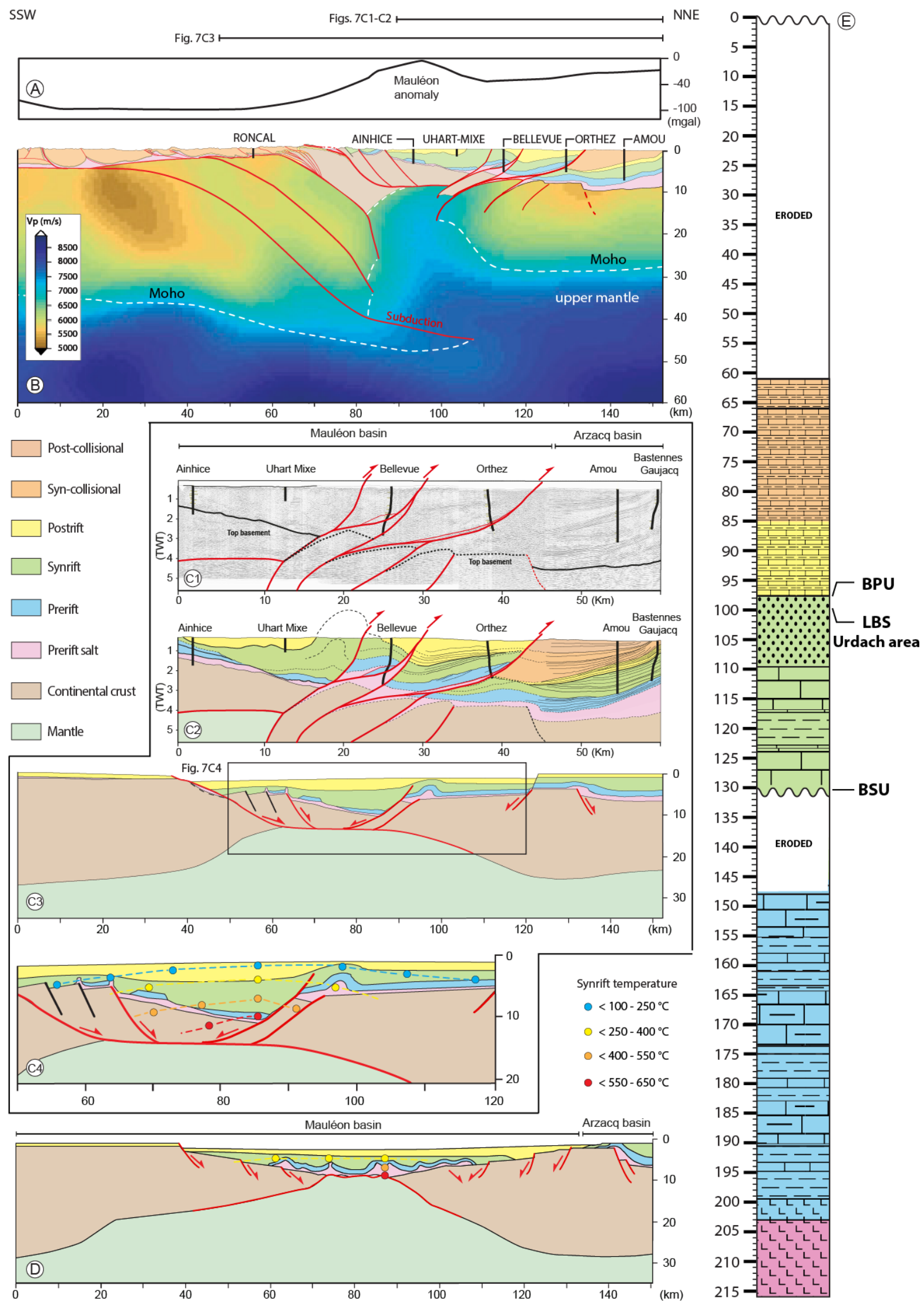


1932 FIGURE 7 Mauléon basin overall architecture. (A) Bouguer anomaly (Casas et al., 1997).

1933 (B) Mauléon basin lithospheric section (see location on Figure 6). The lowermost part 1934 corresponds to the Wang et al. (2016) Vp model showing the presence at shallow depth of 1935 continental lithospheric mantle. The uppermost part is materialized by the Saspiturry et al. 1936 (2020a) crustal-scale balanced cross-section calibrated using (from south to north) the Ronca, 1937 Ainhice, Uhart-Mixe, Bellevue, Orthez, Amou and Bastennes Gaujacq boreholes. (C1, C2) 1938 Geological section through the present-day Mauléon basin based on interpreted seismic lines 1939 and field data (modified from Saspiturry et al., 2019a). The Mauléon basin is exposed within 1940 a pop-up structure formed during N-S Pyrenean compression. (C3) Palinspastic restoration, to 1941 Santonian time, of the Saspiturry et al. (2020a) crustal-scale balanced cross-section. (C4) 1942 Detail of the palinspastic restoration of the Saspiturry et al. (2020a) crustal-scale balanced 1943 cross-section, with RSCM syn-rift paleotemperature of Saspiturry (2019). (D) Palinspastic 1944 restoration, to Santonian time, of the Teixell et al. (2016) crustal-scale balanced cross-section, 1945 with RSCM syn-rift paleotemperature of Corre (2017). (E) Stratigraphic chart showing the 1946 position of the key markers of the Mauléon basin. BSU, basal syn-rift unconformity; LBS, 1947 lithospheric breakup surface; BPU, basal post-rift unconformity. 

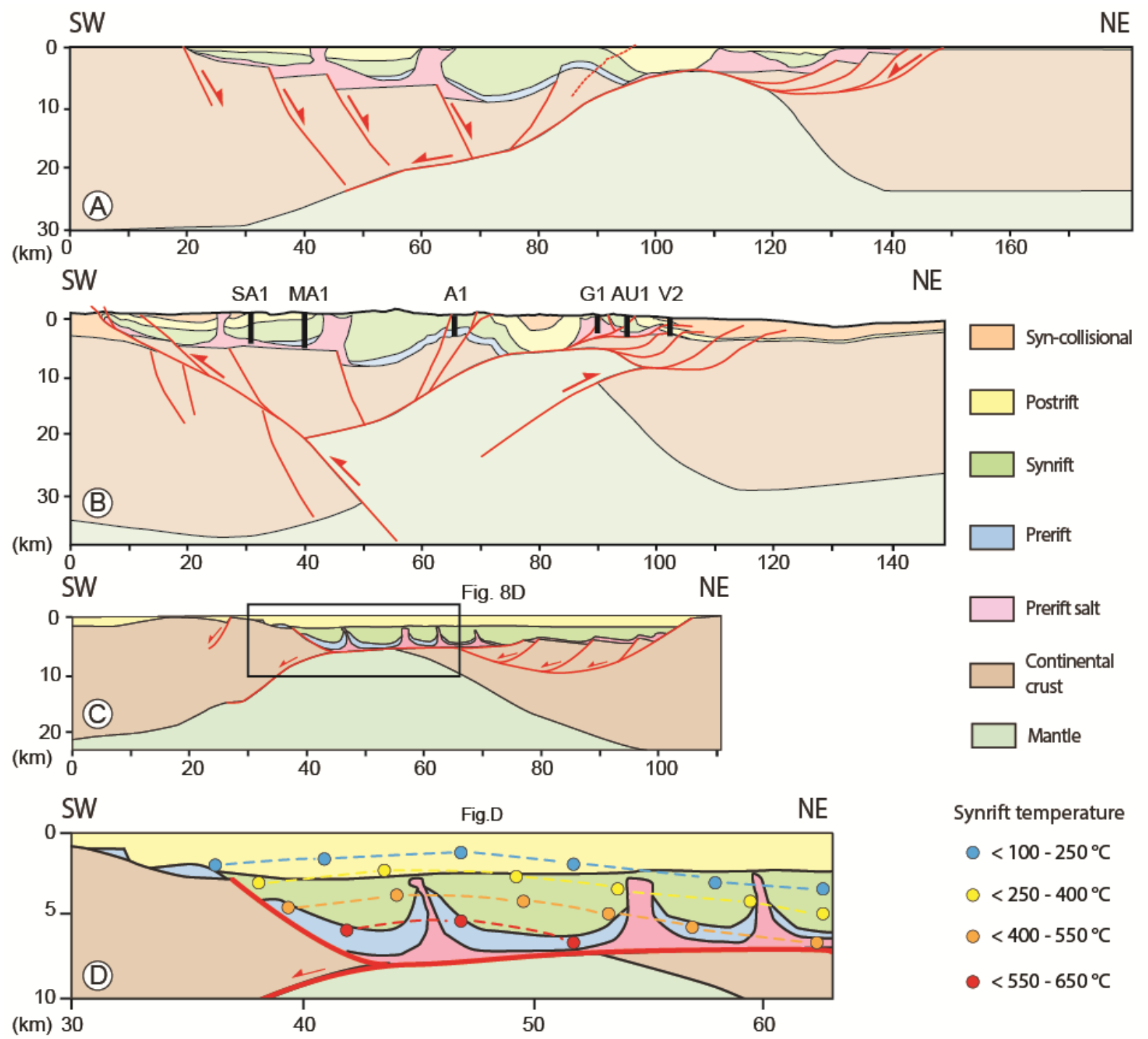

Synrift temperature

$0<100-250^{\circ} \mathrm{C}$

$0<250-400^{\circ} \mathrm{C}$

$0<400-550^{\circ} \mathrm{C}$

- $<550-650^{\circ} \mathrm{C}$

FIGURE 8 (A) Basque-Cantabrian basin palinspastic restoration, to Santonian time, of the

1951 Pedrera et al. (2017) crustal-scale balanced cross-section (see location on Fig. 6). (B) Basque-

1952 Cantabrian basin crustal-scale balanced cross-section (Pedrera et al., 2017), calibrated using

1953 (from south to north) the San Antonio 1 (SA-1), Marinda 1 (MA-1), Arratia 1 (A1), Gernika 1

1954 (G1), Aulesti 1 (AU1) and Vizcaya C2 (V2) boreholes. (C) Schematic restoration of the 1955 eastern part of the Basque-Cantabrian basin in the "Nappe des Marbres" (Ducoux et al., 1956 2019). (D) Detail of (C) with the RSCM syn-rift paleotemperatures measured by Ducoux et 1957 al. (2019). 

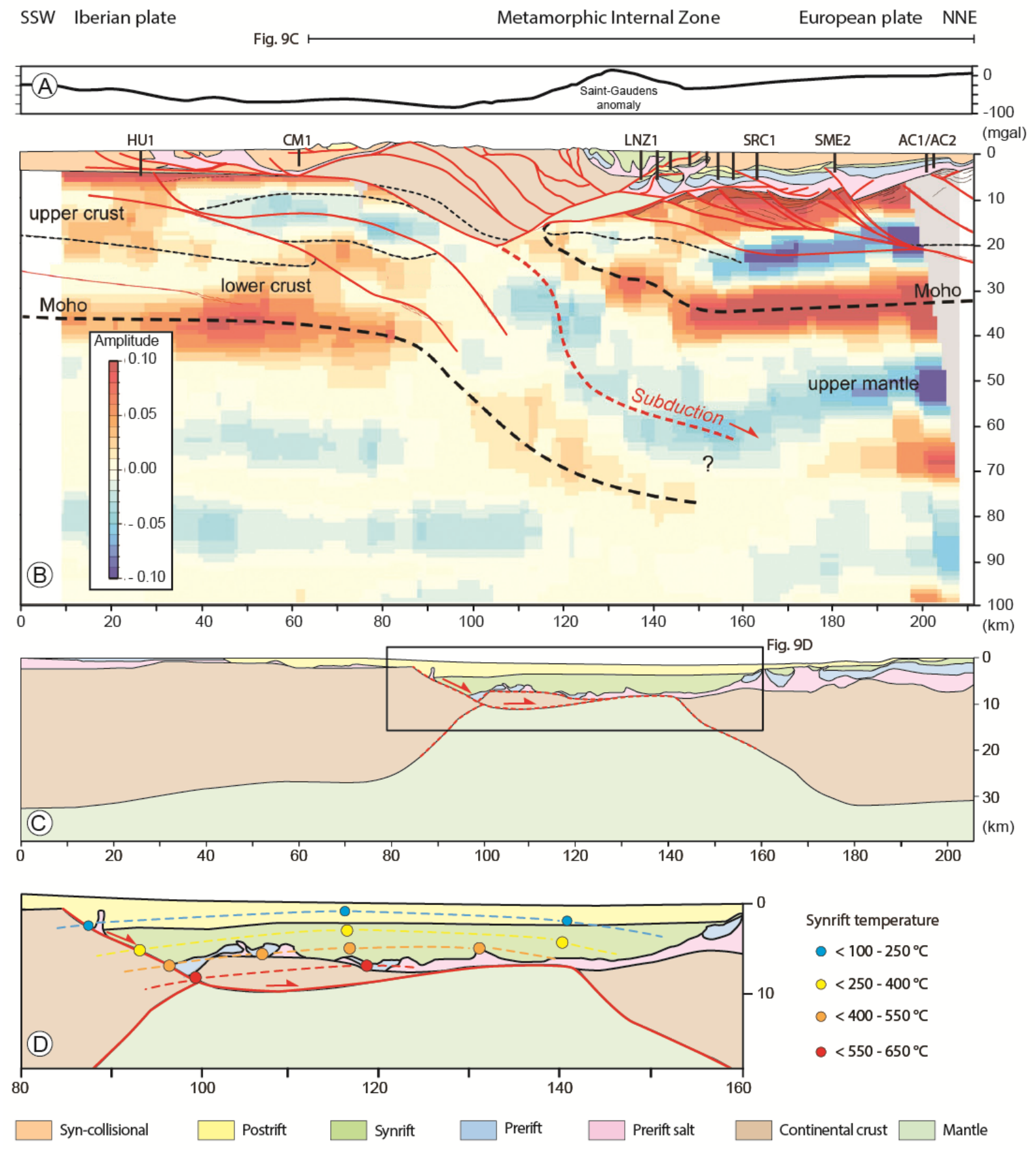

1960 FIGURE 9 Metamorphic Internal Zone overall architecture. (A) Bouguer anomaly (in Espurt

1961 et al., 2019). (B) Metamorphic Internal Zone basin lithospheric section (see location on Figure

1962 6). The lowermost part corresponds to the stack profile of receiver functions for the OROGEN

1963 West profile across the Central Pyrenean belt (in Espurt et al., 2019) showing the presence at 
1964 shallow depth of continental lithospheric mantle. The uppermost part is based on the Espurt et 1965 al. (2019) crustal-scale balanced cross-section calibrated using (from south to north) the 1966 Huesca 1 (HU-1), Campanue-1 (CM-1), Lannemezan 1 (LNZ1), Sariac 1 (SRC-1), Saint 1967 Médard 2 (SME-2), Auch 1 (AC-1) and Auch 2 (AC-2) boreholes. (C) Palinspastic 1968 restoration, to Santonian time, of the Espurt et al. (2019) crustal-scale balanced cross-section. 1969 (D) Detail of the palinspastic restoration of the Espurt et al. (2019) crustal-scale balanced 1970 cross-section, with RSCM syn-rift paleotemperatures. 


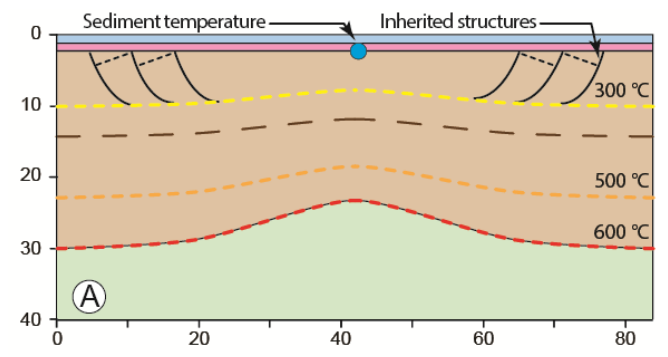

Synrift temperature at the base of the sedimentary record

c $<100-250^{\circ} \mathrm{C}$

$\square$ Synrift cover

o $<250-400^{\circ} \mathrm{C}$

○ $<400-550^{\circ} \mathrm{C}$

- $<550-650^{\circ} \mathrm{C}$
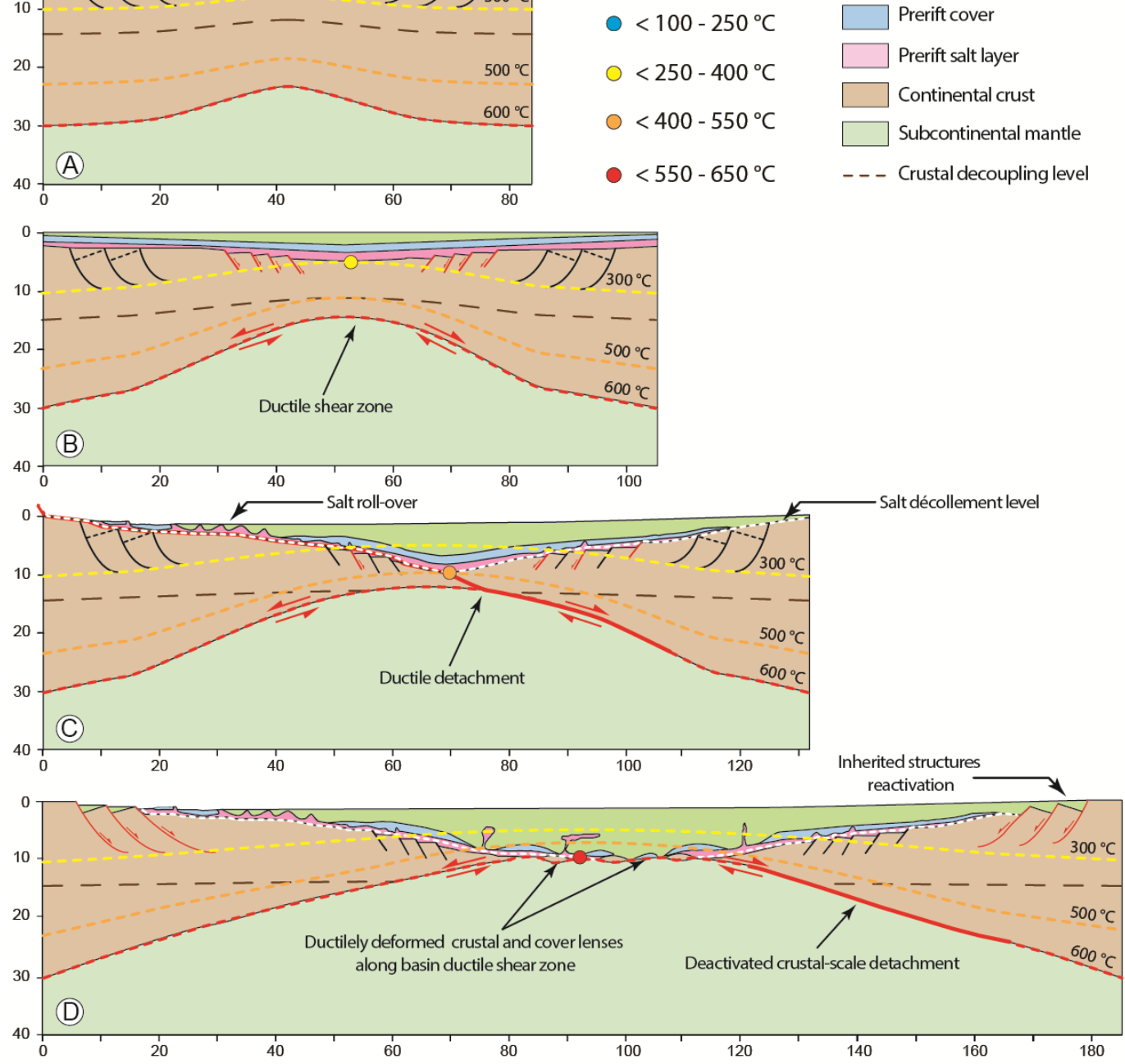

1973 FIGURE 10 Conceptual model of the evolution of a smooth-slope type basin. (A) Inherited

1974 thin lithosphere. (B) Pure shear dominated thinning: formation of a symmetric basin

1975 characterized by shallow-water sediments. (C) Simple shear dominated thinning: basinward

1976 gliding of the pre-rift sedimentary cover along a major detachment connecting towards the

1977 surface with the Late Triassic salt décollement, leading to an asymmetrical basin shape. (D)

1978 Breakup stage resulting in the formation of a pseudo-symmetric basin undergoing brittle

1979 deformation on the proximal margins and ductile deformation in the basin core. No vertical

1980 exaggeration. Coloured dashed lines represent crustal isotherms; coloured circles indicate maximum sediment temperatures during HT/LP metamorphism. 


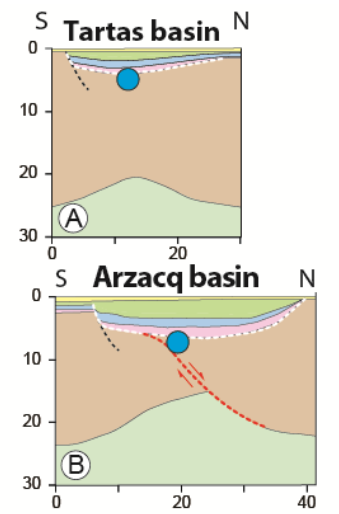

- Salt décollement

_ Ductile detchament

- - - Ductile detchament initiation

Postrift cover

Synrift cover

Prerift cover

Prerift salt layer

Continental crust

Subcontinental mantle

asin
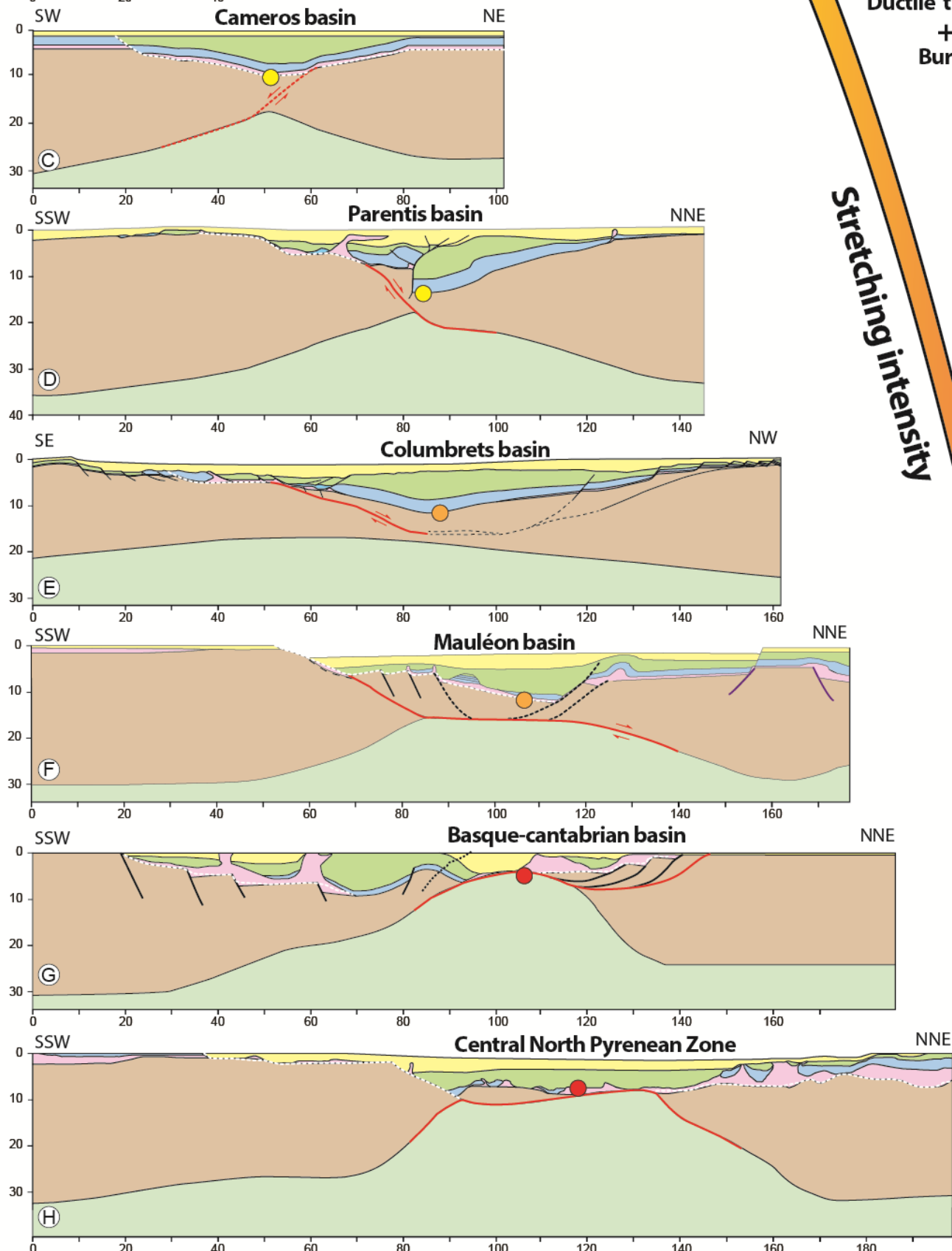

Maximum Stretching Intensity

Increase of :

Lower crust lateral extraction

$+$

Hight synrift thermal gradient

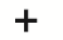

HT/LP synrift metamorphism

$+$

Mantle exhumation

$+$

Ductile thinning

$\stackrel{+}{\text { Burial }}$

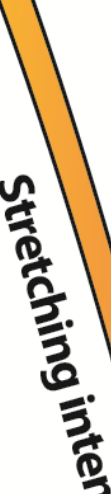

告

NE 
1984 FIGURE 11 Smooth-slope type basins classified according to the degree of continental crust 1985 extension: (A) Tartas sub-basin (Issautier et al., 2020); (B) Arzacq sub-basin (Issautier et al., 1986 2020); (C) Cameros basin (modified after Casas-Sainz \& Gil-Imaz, 1998); (D) Parentis basin 1987 (Tugend et al., 2014); (E) Columbrets basin (Etheve et al., 2018); (F) Mauléon basin 1988 (Saspiturry et al., 2019a); (G) Basque-Cantabrian basin (Pedrera et al., 2017); (H) Central 1989 North Pyrenean Zone basins (Espurt et al., 2019); locations in Figure 1. No vertical 1990 exaggeration. The large arrow indicates the degree of extension and the rise in peak 1991 metamorphic temperatures throughout the basin evolutionary sequence. Coloured circles 1992 indicate maximum sediment temperatures during HT/LP metamorphism. 
$1993 \quad$ Figure.12
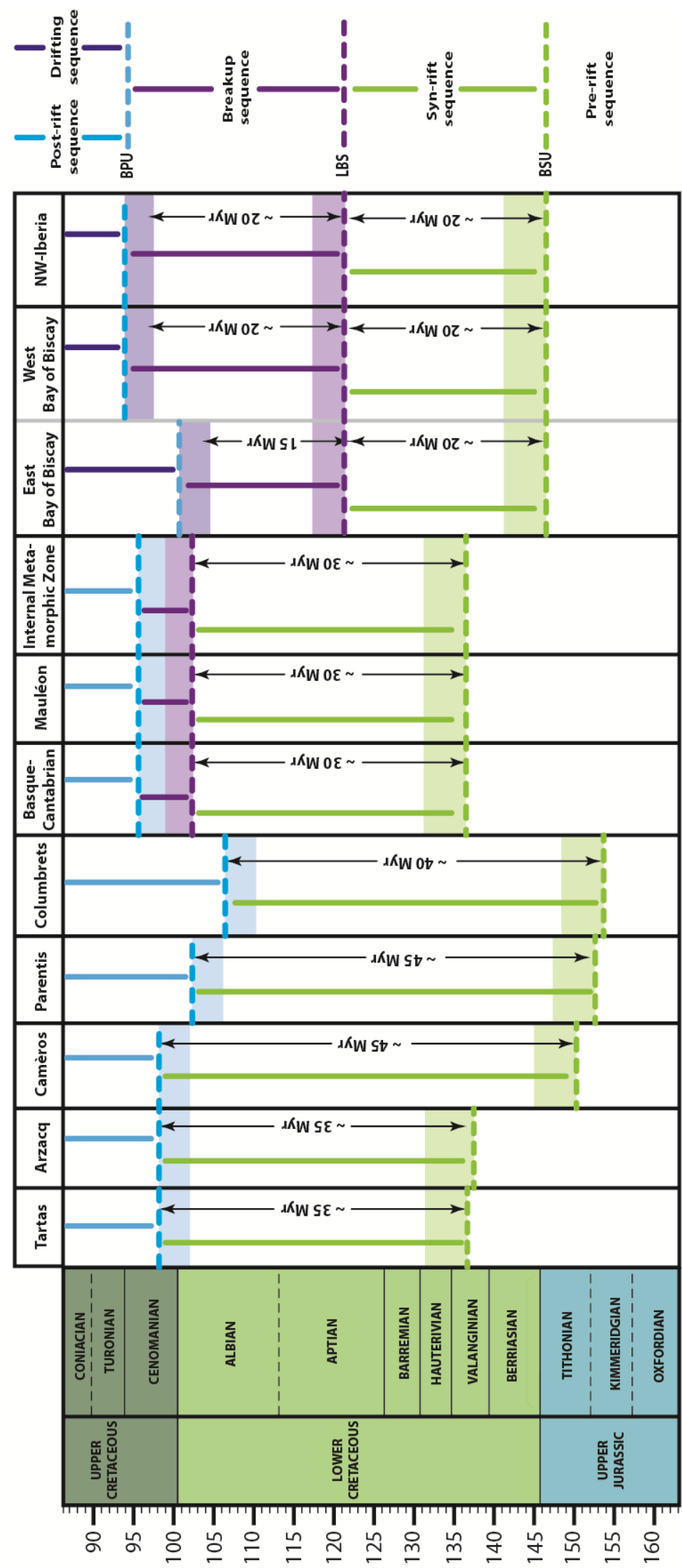
1995 FIGURE 12 Chronological chart showing the timing of the syn-rift, late syn-rift, breakup 1996 (mantle exhumation), post-rift and oceanic spreading events of the reviewed basins, the West 1997 Iberia basins and the Bay of Biscay margins. References used to define the timing of the 1998 different events: Tartas and Arzacq basins (Désaglaux \& Brunet, 1990; Brunet, 1991; Serrano 1999 et al., 2006; Issautier et al., 2020), Camèros basin (Platt, 1990; Mas et al., 1993; Casas-Sainz 2000 \& Gil-Imaz, 1998; Salas et al., 2001; Omodeo-Salé et al., 2014, 2017), Parentis basin (Brunet, 2001 1994; Ferrer et al., 2008; Jammes et al., 2009; Tugend et al., 2015), Columbrets basin (Salas 2002 et al., 2001; Nebot \& Guimerà, 2016; Etheve, 2016; Etheve et al., 2018; Roma et al., 2018), 2003 Basque-Cantabrian basin (Azambre \& Rossy, 1976; Rat et al., 1983; Rat, 1988; García 2004 Mondéjar et al., 1996; Castañares et al., 1997; Castañares \& Robles, 2004; Pedrera et al., 2005 2017; Ducoux et al., 2019), Mauléon basin (Boirie, 1981; Fixari, 1984; Souquet et al., 1985; 2006 Jammes et al., 2009; Debroas et al., 2010; Masini et al., 2014; Teixell et al., 2016; Saspiturry 2007 et al., 2019a; Labaume and Teixell, 2020), Internal Metamorphic Zone basin (Lagabrielle \& 2008 Bodinier, 2008; Lagabrielle et al., 2010, 2019; Clerc \& Lagabrielle, 2014; Clerc et al., 2014, 2009 2015; de Saint Blanquat et al., 2016; Teixell et al., 2018; Espurt et al., 2019), Northwest2010 Iberia margin (Soares et al., 2012; Pereira \& Alves, 2012, Alves \& Cunha, 2018; Alves et al., 2011 2020), and Bay of Biscay margins (Montardet et al., 1979; Brunet 1994; Thinon, 1999; 2012 Thinon et al., 2001, 2003; Gong et al., 2008; Tugend et al., 2015). BSU, basal syn-rift 2013 unconformity; LBS, lithospheric breakup surface; BPU, basal post-rift unconformity. 2014 Coloured shaded areas represent time uncertainty of the BSU, LBS and BPU unconformities. 


\section{Figure.13}
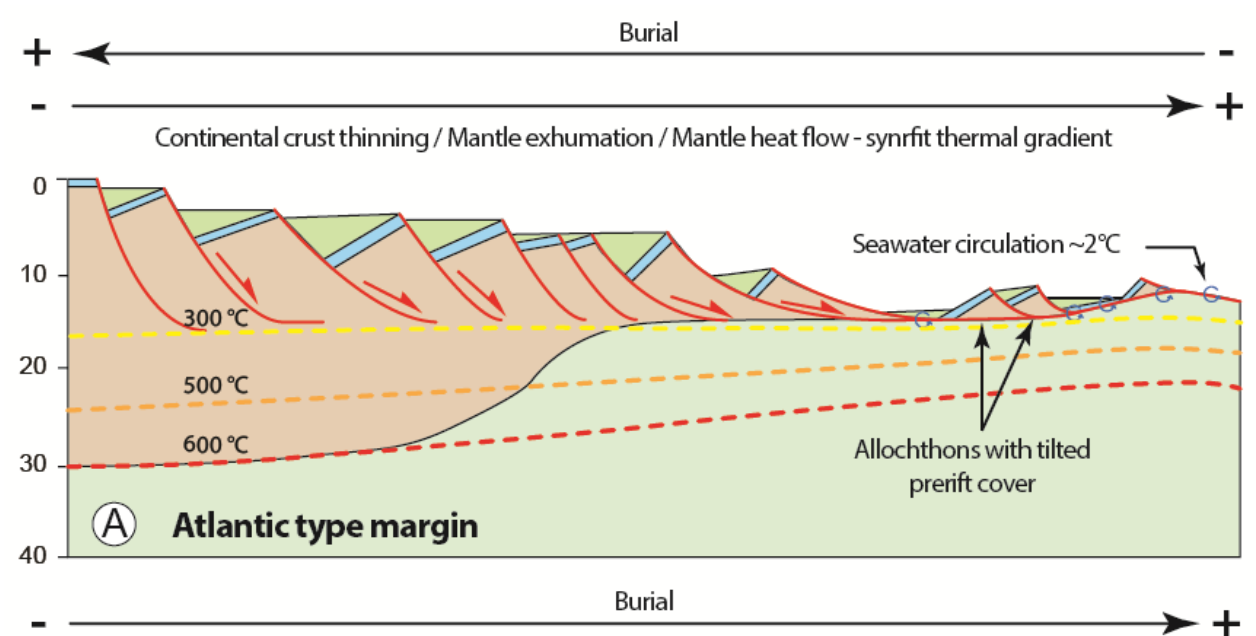

Tilted blocks

Coupled deformation Detachment

Allochthons

Serpentinization

Ophicalcites

Continental crust thinning / Mantle exhumation / Mantle heat flow - synrfit thermal gradient

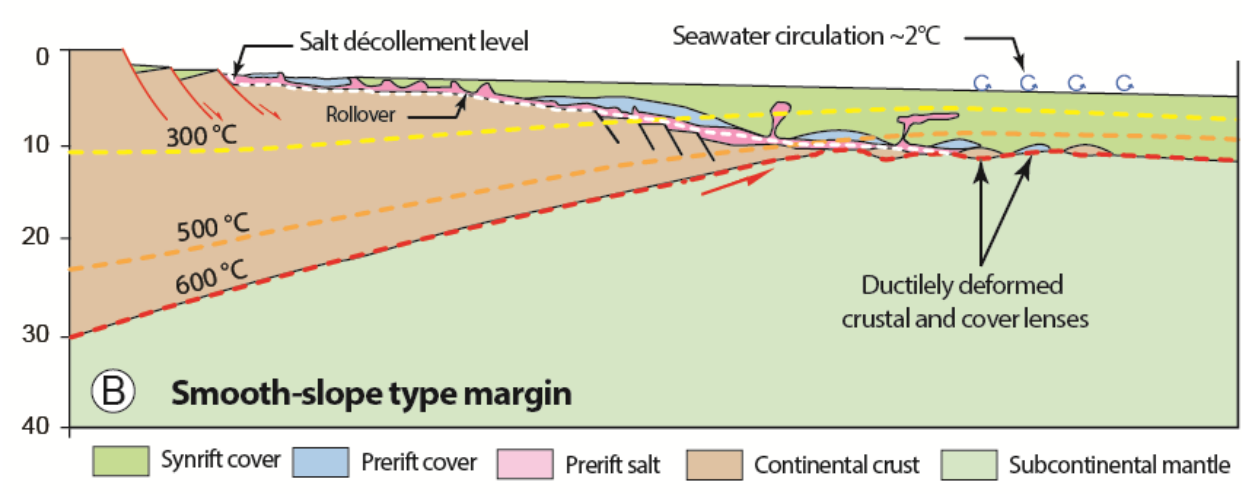

Burial

Ductile deformation

Synrift metamorphism

Ductile thinning

Prerift salt

Cover gliding

Decoupled deformation

Diapirism/salt rollover

2017 FIGURE 13 Schematic diagrams showing (A) Atlantic-type margin architecture (section

2018 modified from Péron-Pinvidic et al., 2015) and (B) smooth-slope type margin architecture.

2019 Coloured dashed lines represent crustal isotherms; coloured circles indicate maximum

2020 sediment temperatures during HT/LP metamorphism. 